\title{
ANÁLISE TÉCNICO-ECONÔMICA DE ALGUNS SISTEMAS DE PRODUÇÃO CITRÍCOLA
}

\section{SÉRGIO GONÇALVES DUTRA}

Engenheiro Agrônomo

Orientador: Prof. Dr. SIZUO MATSUOKA

Dissertação apresentada à Escola Superior de Agricultura "Luiz de Queiroz", Universidade de São Paulo, para obtenção do título de Mestre em Agronomia, Área de Concentração: Fitotecnia.

PIR A CICA B A

Estado de São Paulo - Brasil

Fevereiro -2001 


\section{Dados Internacionais de catalogação na Publicação (CIP) DIVISÃO DE BIBLIOTECA E DOCUMENTAÇĀO - Campus "Luiz de Queiroz"/USP}

Dutra, Sérgio Gonçalves Análise técnico-econônica de alguns sistemas de produção citrícola / Sérgio

Gonçalves Dutra. - - Piracicaba, 2001.

$86 \mathrm{p}$.

Dissertação (mestrado) - - Escola Superior de Agricultura Luiz de Queiroz, 2001. Bibliografia.

1. Análise econômica 2. Citricultura 3. Setor Agrícola 4. Sistema de produção 5. Viabilidade economica I. Título

CDD 634.3

Permitida a conia to tal ou parcial deste documento desde que citad a a fonte = O autor? 


\section{AGRADECIMENTOS}

Ao Prof. Dr. Sizuo Matsuoka por sua orientação e apoio, indispensáveis para a concretização desta dissertação.

Ao Prof. Dr. Antônio Luís Fancelli, Prof. Dr. Durval Dourado Neto e ao Prof. Dr. Hermann Paulo Hoffmann pelas sugestões durante a realização deste trabalho.

Ao Engenheiro Agrônomo Edmundo Eugênio Archelós Blasco que, procurando obstinadamente a sustentabilidade das Fazendas Reunidas Raio de Sol, suscitou a formulação dos propósitos deste trabalho.

Ao Engenheiro Agrônomo Marcelo Ranzini pela permanente colaboração e entusiasmo durante a coleta de dados e o desenvolvimento do presente trabalho.

Aos produtores rurais Antonio Corrocher, Benedito Fernando Brisolari, George Fernando Hoffmann e Virgínia Maria Batistela Chiaradia por franquearem suas propriedades para o desenvolvimento da pesquisa. 


\section{SUMÁRIO}

Página

LISTA DE FIGURAS .......................................................................

LISTA DE TABELAS ................................................................... vii

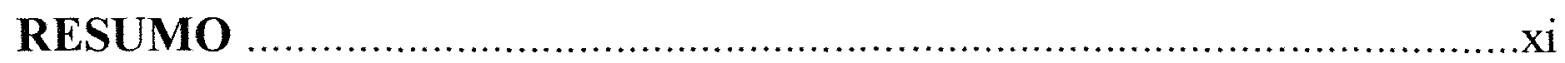

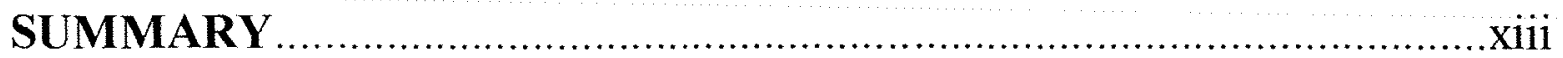

1 INTRODUÇÃO

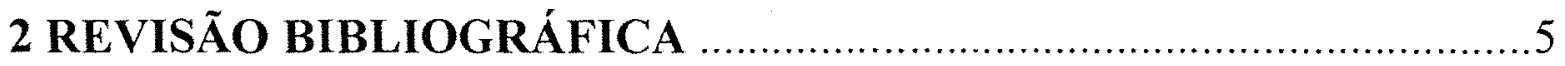

1.1 Importância da citricultura paulista .................................................

1.2 Globalização e desenvolvimento local ............................................6

1.3 Sustentabilidade na agricultura ................................................ 9

1.4 Enfoque sistêmico na pesquisa agropecuária ....................................11

1.5 Comercialização de produtos orgânicos ........................................... 14

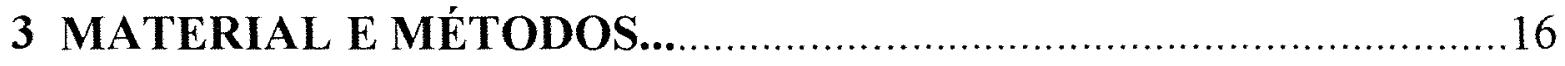

3.1 Definição da área de abrangência da pesquisa ...................................16

3.2. Escolha das cinco propriedades para estudo de caso ..........................19

3.3 Definição das informações a ser obtidas .............................................20

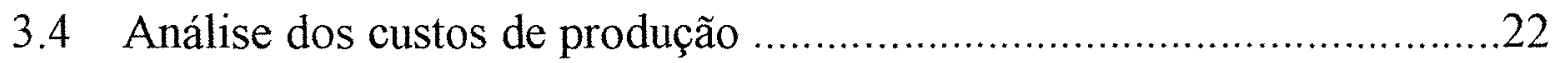

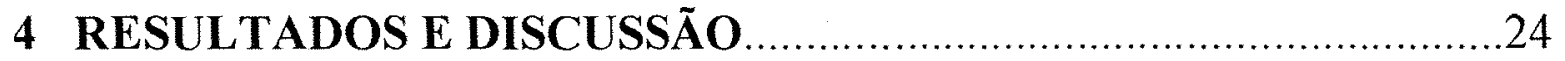

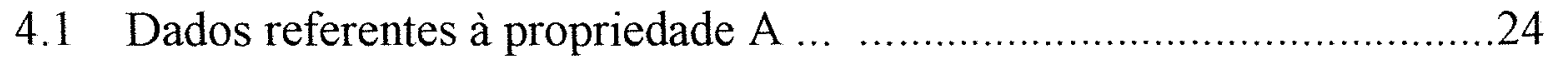

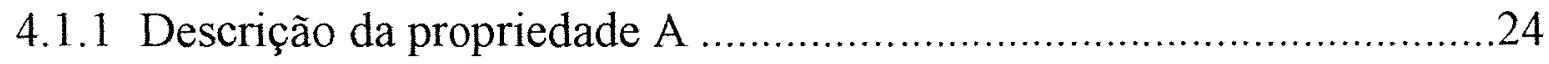

4.1.2 Custos de produção da propriedade A …..........................................2

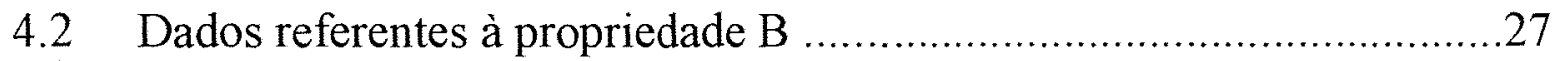

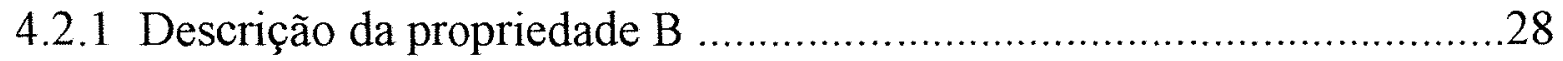

4.2.2 Custos de produção da propriedade B ..............................................31 


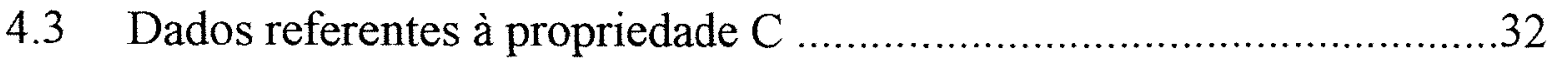

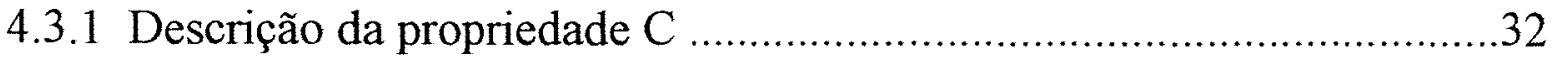

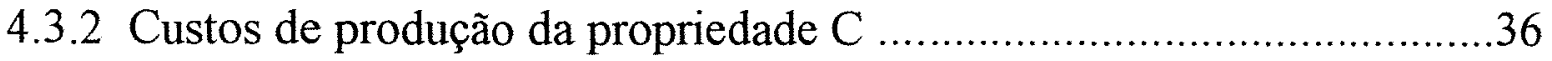

4.4 Dados referentes à propriedade $\mathrm{D}$....................................................36

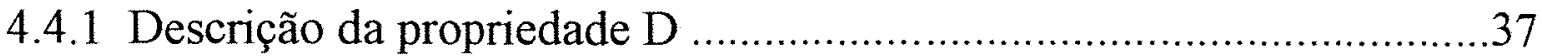

4.4.2 Custos de produção da propriedade D ............................................39

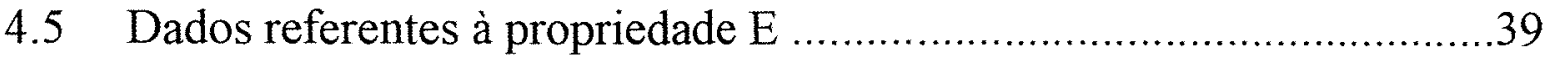

4.5.1 Descrição da propriedade E ..........................................................41

4.5.2 Custos de produção da propriedade E ….........................................43

4.6 Dados referentes às análises de solo .............................................44

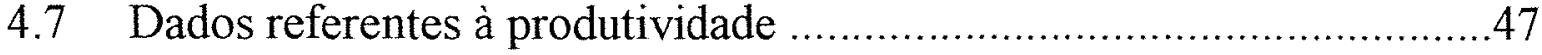

4.8 .. Dados referentes à comercialização.................................................48

4.8.1 Dados referentes à comercialização de produtos orgânicos …............51

5 CONCLUSÕES

AXEXO A: Cálculos dos custos de produção ............................................54

ANEXO B: Tabelas referentes as análises de solo......................................71

ANEXO C: Dados referentes as análises de água.......................................75

ANEXO D: Dados referentes à produtividade .........................................76

ANEXO E: Dados referentes à climatologia................................................77

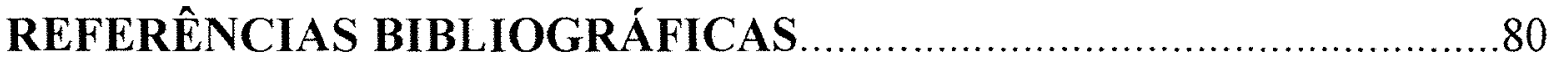




\section{LISTA DE FIGURAS}

Página

1 Regional de Araraquara da Secretaria da Agricultura e Abastecimento do Estado de São Paulo......................................17

2 Regional de Limeira da Secretaria da Agricultura e Abastecimento do Estado de São Paulo.....................................18

3 Configuração atual da empresa Fazendas Reunidas Raio de Sol 40

4 Produção, processamento e consumo de laranja (em milhões de

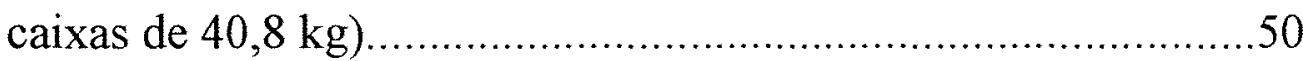

5 Produção citrícola, em milhões de caixas, nas regiões de Araraquara e Limeira, em comparação com o Estado de São Paulo .50 


\section{LISTA DE TABELAS}

Página

1 Resumo dos custos de produção por hectare, em RS, na região de Araraquara, referentes ao ano de 2000, valores corrigidos para janeiro/2001 (AGRIANUAL, 1999).

2 Resumo dos custos de produção por hectare, em $\mathrm{R}$, na propriedade A, referentes às safras 97/98, 98/99 e 99/00, valores corrigidos para janeiro/2001 28

3 Resumo dos custos de produção por hectare, em $\mathrm{R} \$$, na propriedade $B$, referentes às safras 97/98; 98/99 e 99/00, valores corrigidos para janeiro/2001 .32

4 Resumo dos custos de produção por hectare, em RS, na propriedade $C$, referentes às safras 97/98; 98/99 e 99/00, valores corrigidos para janeiro/2001 36

5 Resumo dos custos de produção por hectare, em RS, na propriedade D, referentes às safras 97/98; 98/99 e 99/00, valores corrigidos para janeiro/2001 39

6 Resumo dos custos de produção por hectare, em $\mathrm{R} \$$, na propriedade E, referentes às safras 97/98; 98/99 e 99/00, valores corrigidos para janeiro/2001 44

7 Análises de solo realizadas nos anos de 1998, 1999 e 2000 em talhões de laranja pêra de cinco propriedades da região de São Carlos, SP

8 Produção de citros por pé (caixas de $40,8 \mathrm{~kg}$ ), variedade "pêra", em talhões de cinco propriedades da região de São Carlos, SP...48 
9 Preços obtidos* por caixa de $40,8 \mathrm{~kg}$ da laranja pêra pelos proprietários de cinco pomares da região de São Carlos, SP.

10 Exportações brasileiras de suco concentrado de laranja (FCOJ), no ano de 2000, expressa em toneladas.

11 Número total de agricultores certificados pela Associação de Agricultura Orgânica (AAO) até maio de 2000

A1 Custos de produção por hectare, na região de Araraquara, em R\$, referentes ao ano de 2000, valores corrigidos em R\$ janeiro/2001 (AGRIANUAl, 99)

A2 Custos de produção por hectare, na propriedade $A$, em R\$, referentes a safra e 97/98, valores corrigidos em R\$ janeiro/2001

56

A3 Custos de produção por hectare, na propriedade $\mathrm{A}$, em $\mathrm{R}$, referentes a safra e 98/99, valores corrigidos em R\$ janeiro/2001

57

A4 Custos de produção por hectare, na propriedade A, em RS, referentes a safra e 99/00, valores corrigidos em R\$ janeiro/2001 58

A5 Custos de produção por hectare, na propriedade $B$, em $R \$$, referentes a safra e 97/98, valores corrigidos em R\$ janeiro/2001

A6 Custos de produção por hectare, na propriedade B, em R\$, referentes a safra e 98/99, valores corrigidos em RS janeiro/2001 
A7 Custos de produção por hectare, na propriedade $B$, em $R \$$, referentes a safra e 99/00, valores corrigidos em $\mathrm{R} \$$ janeiro/2001

A8 Custos de produção por hectare, na propriedade $C$, em $R \$$, referentes a safra e 97/98, valores corrigidos em $\mathrm{R} \$$ janeiro/2001

A9 Custos de produção por hectare, na propriedade $C$, em $R \$$, referentes a safra e 98/99, valores corrigidos em $\mathrm{R} \$$ janeiro/2001

A10 Custos de produção por hectare, na propriedade $C$, em $R \$$, referentes a safra e 99/00, valores corrigidos em $\mathrm{R} \$$ janeiro/2001

A11 Custos de produção por hectare, na propriedade $\mathrm{D}$, em R\$, referentes a safra e 97/98, valores corrigidos em $\mathrm{R} \$$ janeiro/2001

A12 Custos de produção por hectare, na propriedade $\mathrm{D}$, em $\mathrm{R} \$$, referentes a safra e 98/99, valores corrigidos em R\$ janeiro/2001 66

A13 Custos de produção por hectare, na propriedade $\mathrm{D}$, em $\mathrm{R} \$$, referentes a safra e 99/00, valores corrigidos em $\mathrm{R} \$$ janeiro/2001

A14 Custos de produção por hectare, na propriedade $E$, em $R \$$, referentes a safra e 97/98, valores corrigidos em R\$ janeiro/2001

A15 Custos de produção por hectare, na propriedade $\mathrm{E}$, em $\mathrm{R} \$$, referentes a safra e 98/99, valores corrigidos em $\mathrm{R} \$$ janeiro/2001 
A16 Custos de produção por hectare, na propriedade $E$, em R\$, referentes a safra e 99/00, valores corrigidos em RS janeiro/2001 70

B1 Análises de solo - micronutrientes - propriedade B data:

$10 / 09 / 98$ 71

B2 Análises de solo - micronutrientes - propriedade $\mathrm{C}$ data: 04/09/98. 71

B3 Análises de solo propriedade D - data: 30/08/99 ....................72

B4 Análises químicas de planta - propriedade D data: $25 / 05 / 99$ .73

B5 Análises químicas do solo da propriedade D - data: $06 / 07 / 2000$ 73

B6 Análises de solo da propriedade D - data: 31/08/2000_...........74

B7 Análises químicas de planta da propriedade D - DATA: $30 / 05 / 00$ 74

C1 Análises da água de irrigação, realizadas em agosto/2000, nas

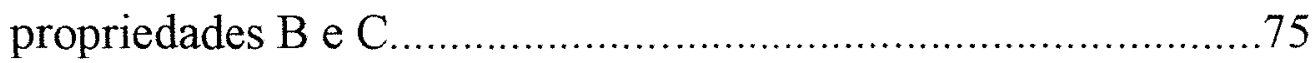

D1 Produção das variedades de citros da propriedade D.................76

D2 Produção de diversas variedades de citros da propriedade E.......76

E1 Boletim pluviométrico CEAPLA-IGCE-UNESP 1998 ..............77

E2 Boletim pluviométrico CEAPLA-IGCE-UNESP 1999 .............78

E3 Boletim pluviométrico CEAPLA-IGCE-UNESP 2000 .............79 


\title{
ANÁlISE TÉCNICO-ECONÔMICA DE ALGUNS \\ SISTEMAS DE PRODUÇÃO CITRÍCOLA
}

\author{
Autor: SÉRGIO GONÇALVES DUTRA \\ Orientador: Prof. Dr. SIZUO MATSUOKA
}

\section{RESUMO}

O Brasil é o maior exportador de sucos cítricos do mundo e em São Paulo se concentra a sua produção. Para a grande produção de frutas cítricas necessárias para atender tal mercado, a citricultura paulista se modernizou e se tornou refém de um modelo considerado de alta tecnologia, baseado no uso intensivo de insumos da chamada Revolução Verde. Todavia, como em todo o setor agrícola mundial, na citricultura também já se faz notar agricultores incorporando a preocupação da sociedade com a preservação ambiental e que, dessa forma, com ousadia passam a adotar práticas alternativas de manejo agrícola ambientalmente mais amigável. Visando obter subsídios para orientação, evolução e disseminação desse tipo de prática citrícola, fez-se este estudo de indicadores técnico-econômicos do sistema alternativo adotado numa propriedade da região de São Carlos, SP, comparando-o com os de quatro outras da mesma região. Elas foram acompanhadas durante três anos, especialmente na área de fertilidade dos solos e custos de produção. As práticas adotadas consistem basicamente em usar a Brachiaria ruziziensis com a dupla função de cultura de 
cobertura e recicladora de nutrientes, aplicando os fertilizantes (dentro de parâmetros de baixo consumo) sobre essa gramínea, e pulverizar biofertilizante e calda sulfocálcica como trato fitossanitário. Em oito anos de evolução desse sistema, o solo tornou-se produtivo e os indicadores levantados comprovaram a sua sustentabilidade econômica, mesmo sendo o solo predominantemente NEOSSOLO QUARTZARÊNICO Órtico, de baixíssimo potencial agrícola, o pior de todos os estudados. Dado que se comprovou a viabilidade econômica de produção de citros com uma forma alternativa de manejo em substituição ao convencional predominante, configura-se a necessidade da definição de políticas públicas e maior apoio institucional para iniciativas que buscam a redução do consumo de agrotóxicos e fertilizantes de alta solubilidade, assim preservando o ambiente e oferecendo à sociedade alimentos mais saudáveis. 


\title{
TECHNICAL AND ECONOMICAL ANALYSIS OF SOME
}

\section{CITRUS PRODUCTION SYSTEMS}

\author{
Author: SÉRGIO GONÇALVES DUTRA \\ Adviser: Prof. Dr. SIZUO MATSUOKA
}

\section{SUMMARY}

Brazil is the biggest world exporters of freeze and concentrated orange juice (FCOJ) and in the State do São Paulo is concentrated the production of citrus fruit. In order to attend the demand for that big orange juice industry the citrus culture of that state has modernized and adopted the technology based on dependence to high levels of input and energy of the Green Revolution ideology. However, as the same in other agricultural sectors worldwide, some citrus producers are incorporating the society claim to environmental clean systems, daringly adopting alternative practices considered being environmentally friendlier. In order to obtain subsides to guide, evolve and disseminate that kind of procedure, this study of technical and economical indicators in an alternative system of citrus orchard management adopted in a farm located in one of the most important citrus production center of the state (São Carlos) has been carried out. That system has been confronted to conventional systems adopted by four other farms of the same region, during three years, mainly in terms of soil fertility and costs of production. The basic management adopted in that specific farm is the use of the grass Brachiaria ruziziensis both as a cover plant and as a nutrient recycler. Additionally, it is applied a biofertilizer and sulphocalcic mixture as crop protection measures. In eight years of evolution of that system, the soil has turned to be productive and the indicators 
has proved the economical sustainability of the system, even most of its soil being NEOSSOIL QUARTZARENIC Ortic, that is, of very low production potential. So, the viability of citrus production by management procedures alternative to the prevalent one has been demonstrated. This fact point to the necessity to define a more strong political agenda in favor of initiatives that searches for an agricultural sustainable development, as they led to a minor use of xenobiotic chemicals and offer to the society more healthful food. 


\section{1- INTRODUÇÃO}

A partir da Segunda Guerra Mundial, as transformações sociais, econômicas e tecnológicas têm ocorrido de maneira muito rápida em todo o mundo, sobressaltando os efeitos danosos da ação antrópica no Planeta. Resulta, então, que os movimentos ambientalistas passam a ter maior espaço na mídia eletrônica e no cenário político mundial, especialmente a partir dos anos 80 . $\mathrm{Na}$ área agrícola, o perfil da atividade desenvolvida tem levado a uma série de impactos, tanto positivos como especialmente negativos (Chaboussou, 1985; Campanhola et al., 1996; Frighetto, 1997), principalmente nos paises desenvolvidos do Hemisfério Norte. No Brasil, este fenômeno é mais evidente nos Estados e regiões brasileiras onde a agricultura é mais intensiva e tecnicista (Região Sul, Estado de São Paulo, Triângulo Mineiro, sul de Goiás). Em conseqüência, avolumamse as teses que se contrapõem à chamada "Revolução Verde" (utilização intensiva de agroquímicos e com alto consumo de energia), colocando em foco questões até então negligenciadas, como a sustentabilidade dos agroecossistemas (Ehlers, 1995; Campanhola et al., 1996; Romeiro \& Salles Filho, 1996 ).

"A agricultura moderna não prima pela ciclagem dos nutrientes: os restos vegetais são queimados ou manejados de forma imprópria. $\mathrm{O}$ aumento da lixiviação dos nutrientes e a erosão dos solos contribuem para uma perda significativa, além, é claro, da grande exportação de nutrientes através da produção. A conseqüência é o desequilíbrio nutricional, exigindo reposição brutal através dos fertilizantes químicos", são palavras de Ferraro Jr. (2000), ao apontar alguns problemas estruturais do sistema agricola dominante.

De acordo com o Conselho de Alimentos da FAO/ONU "Desenvolvimento Agrícola Sustentado é o gerenciamento e conservação da base dos recursos naturais e a orientação da mudança tecnológica e institucional, assegurando a realização e satisfação continuada das necessidades humanas para gerações presentes e futuras". Consoante esse pressuposto, países do chamado Primeiro Mundo (Japão, Europa Ocidental, Estados 
Unidos, etc), vêm intensificando suas atividades de pesquisa e produção sob o prisma da agricultura sustentável.

Nos diferentes conceitos colocados em discussão, é visível a preocupação em não se estabelecer um "pacote tecnológico" da agricultura sustentável, dado o seu caráter holístico e multidisciplinar. A sustentabilidade só pode ser atingida mediante a consideração do enfoque sistêmico de produção, abolindo de forma sumária a uniformização de técnicas e o emprego de fórmulas pré-estabelecidas e genéricas de manejo (Fancelli, 1994) e, conseqüentemente, seu prazo de estabelecimento (Ferraro Jr., 2000).

A utilização do enfoque sistêmico como método de condução de pesquisa e extensão agropecuária é relativamente recente no Brasil, tendo se intensificado a partir da segunda metade da década de 80 . As instituições que iniciaram tal processo o fizeram através de consultorias externas e/ou enviaram seus recursos humanos para treinamento no exterior, em razão da inexistência de formação específica em sistemas de produção no quadro de disciplinas das instituições de ensino brasileiras. Porém, "dadas as características da Pesquisa e Extensão agrícola no país, que tradicionalmente privilegiaram a geração e adaptação de tecnologias por produto, a internalização da investigação sob enfoque sistêmico tem enfrentado dificuldades de aceitação e até de divulgação" (IAPAR, 1993).

O enfoque sistêmico nas condições atuais apresenta-se, em tese, como uma ferramenta eficiente na busca da tão idealizada "agricultura socialmente justa, economicamente viável, ecologicamente equilibrada e sustentável em longo prazo". No momento, entretanto, todos parecem concordar que a agricultura sustentável é ainda um anseio; o que varia é a expectativa em relação ao grau das mudanças contidas nesse objetivo. E então uma questão fundamental se coloca: como atingir esses objetivos na prática? Especialmente porque, o estudo dessa questão, principalmente nos trópicos, requer maior embasamento científico e tecnológico, e deve levar em consideração uma 
premissa fundamental: "a pesquisa e o desenvolvimento agrícola devem começar e finalizar no produtor" (Rhodes e Booth, 1982).

"A busca de um novo paradigma de desenvolvimento e uma ação efetivamente integrada organicamente, entre os diversos agentes/instituições voltadas ao desenvolvimento, se de um lado dependem certamente de pressão e vontade política, por outro lado depende completamente de um profissional-sujeito capaz de contribuir nessa ação-reflexão" (Mussoi, E. M., IAPAR, 1993). Uma análise abrangente do processo produtivo que considere todas as suas interfaces, bem como o seu caráter multidisciplinar, contemplando a produção, o processamento (quando se fizer presente), e a comercialização, pode trazer contribuições para as necessidades acima mencionadas.

Um fato relevante é que em nosso país já se dispõe junto aos agricultores de uma série de experiências produtivas que seguem os princípios da preservação ambiental e da sustentabilidade, a maioria delas no Estado de São Paulo (Dulley, 2000). Elas têm gerado significativa quantidade de informações, mas nem sempre sistematizadas adequadamente ou analisadas sob um prisma científico, e que podem contribuir de forma significativa para a pesquisa agronômica.

Com a finalidade de inserir a presente proposição de pesquisa em uma área mais definida do conhecimento agronômico, fez-se a opção, no tocante à produção, de se centrar a análise na citricultura, pois a mesma coloca-se, após a cana-de-açúcar, como a principal cultura da região em que a pesquisa foi desenvolvida, seja no tocante à área plantada, seja no que diz respeito ao volume de produção e ao montante de recursos técnicos e financeiros envolvidos. Segundo a FIBGE, em 1996 o Estado de São Paulo detinha $82,9 \%$ da produção nacional de laranja, sendo que $88 \%$ do número total de pés de laranja plantados estavam inseridos no chamado cinturão citrícola paulista, abrangendo as regiões de Araraquara, Barretos, Campinas, São Carlos e São José do Rio Preto, considerado o maior centro produtor de laranja do mundo. 
Foi na região acima citada que foi realizado acompanhamento técnicoeconômico de cinco propriedades citrícola, com destaque para uma delas que, nos últimos oito anos, vem intensificando seus esforços na recuperação da capacidade produtiva de seu solo através da reciclagem equilibrada de nutrientes, ao mesmo tempo em que tem buscado a supressão do uso de agrotóxicos e insumos que dependam de matriz energética importada de outros países. Dos longos anos de teste e avaliação da produção nessa propriedade, a despeito das grandes dificuldades de comercialização nas últimas três safras, resultaram a obtenção de talhões altamente produtivos, onde já está sendo suprimido o uso de biocidas, de origem sintética e industrial, no controle de pragas e doenças e no manejo de invasoras, possibilitando a abertura de mercados de exportação na área de produtos citrícola ambientalmente certificados. 


\section{2- REVISÃO BIBLIOGRÁFICA}

\section{1 - Importância da citricultura paulista}

Segundo dados sobre a fruticultura mundial (FAO, 1996), os citros ocupam o $1^{\circ}$ lugar em volume físico de produção, respondendo por $22,8 \%$ do total do setor, num total de 93,8 milhões de toneladas. Hasse (1987) cita que "quarenta ou cinqüenta séculos depois da sua presumível domesticação, a laranja tem seu maior volume de produção nas Américas, onde foi introduzida há 500 anos. São Paulo, no Brasil, e a Flórida, nos Estados Unidos, são as principais regiões produtoras do mundo.

Na década de noventa, por diversas vezes a produção brasileira superou a casa dos 400 milhões de caixas anuais, sendo que o Estado de São Paulo detém mais de 4/5 do total (IEA, 1997). Pelos dados da Associação Brasileira dos Exportadores de Cítricos - ABECITRUS, existem cerca de 20.000 estabelecimentos agrícolas no Estado de São Paulo que têm como atividade principal a citricultura. A última estimativa divulgada pelo Instituto de Economia Agrícola (IEA), prevê uma safra de 365 milhões de caixas de $40,8 \mathrm{~kg}$ para 2000/01. Trata-se da segunda redução apresentada em relação à previsão inicial de 380 milhões de caixas. A produção paulista destina-se prioritariamente para o processamento industrial, voltado para a exportação do suco de laranja concentrado e congelado (SLCC) (Escobar et al., 1999), ou FCOJ (em inglês).

Por se tratar de uma commodity, quando o preço no mercado internacional cai em função do aumento da oferta, há excedente de laranja para ser consumida in natura no mercado interno brasileiro, uma vez que as exportações de fruta fresca nunca foram representativas (não chegando a $1 \%$ do total da produção) e vem se reduzindo nos últimos anos (ABECITRUS, 2001). 
2-2 - Globalização e desenvolvimento local

Nos últimos dez anos tem se intensificado o chamado processo de globalização, sendo que muitas concepções e análises vêm sendo elaboradas e debatidas. Segundo Bonanno et al. (1999), “apesar dessas análises variarem muito em termos de suas características analíticas, todas elas reafirmam que tem havido uma reorganização do espaço das relações sociais, o que tem provocado impactos importantes tanto na produção como no consumo, bem como sobre as esferas culturais e políticas". Aqueles autores afirmam também que "uma das mais interessantes caracteristicas do período pós-Fordista Global tem sido o desenvolvimento de novas sensibilidades culturais sobre a qualidade do consumo. Para a agricultura e para os alimentos, este fenômeno se traduz no desenvolvimento de um grau avançado de consciência sobre a qualidade dos produtos alimentares e na legislação para a manutenção de padrões de consumo de alta qualidade".

Bonanno et al. (1999) afirmam que "a globalização significa que a expansão das forças produtivas não necessariamente se traduz em recursos que poderiam ser empregados para o crescimento da sociedade". No novo modelo de acumulação, centrado na globalização, ganha função estratégica a criação de cadeias de commodities, onde se busca facilitar a alocação dos fatores de produção.

Em muitos casos têm ocorrido queda dos preços internacionais das principais commodities agrícolas, muitas vezes associado a uma desatenção nas questões ambientais e trabalhistas, colocadas em segundo plano, na busca de reduzir os custos e aumentar a flexibilidade da produção. Entretanto, Bonanno et al. (1999) consideram que "esta situação não significa que as possibilidades de crescimento socioeconômico que poderiam beneficiar grandes segmentos da sociedade, incluindo aí os grupos subordinados, estão automaticamente excluídas. Ao contrário, isso indica que novas alternativas são possiveis. Essas novas alternativas, entretanto, requerem um exame crítico e minucioso 
dos mecanismos colocados na ordem do dia pelas forças da globalização". Ainda segundo Bonanno et al. (1999), "a exclusão dos circuitos globais não tem sua contrapartida em termos de proteção social aos grupos e regiões que sofrem as conseqüências da globalização". Daí que as ações locais deveriam ser dirigidas para uma redefinição da participação nas cadeias de commodities através de uma reorganização de prioridades.

Segundo Müller (1995), “a integração da produção agrária nas relações socioeconômicas do complexo agroindustrial de um lado e nas relações comunitárias locais-regionais de outro, abre oportunidades de encaminhar - não resolve de uma vez - os problemas existentes pelos processos herdados e pelos problemas potenciais oriundos da nova e mais radical modernização do agribusiness. A realização dessas oportunidades requer incentivos econômicos e culturais e políticas inovadoras, que busquem nova forma de gestão política e pública".

Destaca-se, então, o conceito de "localidade", sendo que, de acordo com Kageyama (1998), "as localidades rurais são caracterizadas como pontos de encontro de diversos conjuntos de relações sociais que interagem em forma de redes, que conformarão o seu caráter material e social”. Esse aspecto é detalhado por Murdoch e Marsden (1994) que ressaltam que "a localidade rural pode ser considerada como uma série de resultados físicos e sociais surgidos à medida que os atores perseguem seus objetivos no interior dessas redes. A localidade é assim um ponto de encontro, onde redes se interceptam e onde alguns atores podem impor seus interesses sobre outros. Com o tempo, esses resultados vão se compondo para dar lugar a uma formação socioespacial".

Em sua análise sobre a importância do território na formação das redes de poder, Paulillo (2000) coloca que "os encadeamentos tecnológicos e produtivos apresentam algumas características básicas: a interdependência dos atores, a complementaridade dinâmica dos segmentos, a troca de recursos de poder e a articulação dos interesses. Essas características podem promover um processo de interação estratégica 
ou de coalizão política entre os atores privados (individuais e coletivos) e as agências públicas do Estado. Podem ocorrer diversos arranjos institucionais que envolvem, de maneira diferenciada, segmentos estatais e privados na formulação e implementação de políticas públicas em cada encadeamento. Nesses arranjos, aparecem com destaque as questões sobre as formas de organização, mobilização e representação dos interesses dos atores, que influenciam a realização das politicas públicas. Assim, podem se formar redes políticas em torno dos interesses e dos recursos de poder envolvidos".

Considerando o território como resultado de uma construção social e política, na qual os atores coletivos e individuais interagem e articulam interesses, formando uma estrutura de oportunidades diferenciada, onde a questão territorial pode ser um elemento estratégico relevante, a elaboração e aplicação de políticas públicas que levem em consideração esse conceito, caracterizam-se como importante objeto de análise e pesquisa. Segundo Kageyama (1998), “a referência espacial relevante (região) é a economia local (a cidade e seu entorno rural) que forma o ambiente produtivo ou contexto. A análise da capacidade de desenvolvimento das áreas rurais - dada pela sua diversificação interna e suas formas de integração com o exterior - deve ter, portanto, dois pólos, as empresas (ou as famílias) e o contexto ou economia local em que se inserem".

Segundo Paulillo (2000), "a formulação e a implementação de políticas públicas se fazem por verdadeiros arranjos institucionais, proporcionados pelas organizações de interesses privados específicos, as agências públicas governamentais e as não governamentais. Estes arranjos institucionais estão cada vez mais dependentes do concerto social destes grupos e organizações de interesses que da regulação espontânea do mercado ou da regulação imposta pelo Estado". 


\section{2-3 - Sustentabilidade na agricultura}

Nestes últimos anos tem sido muito debatida a "sustentabilidade" das atividades humanas e, por extensão, a questão da "agricultura sustentável" (ex: Altieri, 1987; Gliessmann, 1990; Carrol et al., 1990; Bonilla, 1992; Reijntjes et al., 1994), especialmente em razão de constatações e críticas sobre os efeitos negativos de certos métodos de produção agrícola (ex: Pimentel (1977); Paschoal, (1979); Primavesi, 1981; Conway \& Barbier, 1990; Brown \& Young, 1990; Shiva, 1991; Romeiro \& Salles Filho, 1996), sobressaltados após a clássica publicação de Raquel Carson, Primavera Silenciosa, em 1962.

O termo "sustentável", que é um adjetivo derivado do verbo latino sustentare, significa "que pode ser mantido". Fica assim implícito na definição o fator tempo. Dessa forma, só é sustentável o desenvolvimento ou modelo agrícola que pode ser mantido no tempo, ou idealmente que pode ser perpetuado (Paschoal, 1995).

Segundo Lynam \& Herdt (1989), a sustentabilidade pode ser assim definida: "como a capacidade do sistema em manter a produtividade a um nível aproximadamente igual ou maior que a média histórica, esta sendo determinada através de uma aproximação analisando-se a variação histórica". Afirmam ainda que "sustentabilidade é representada por um sistema que apresenta uma tendência não negativa na sua produtividade”.

Dois itens podem ser destacados no qual o termo "sustentabilidade" é usado em relação produtividade de um sistema, Lynam \& Herdt (1989):

pode ser usado para descrever a propriedade ou a característica da "produtividade" de um sistema;

pode referir-se à adoção de um determinado sistema que poderá ser sustentável ou mantido.

Apesar de ainda restrita, a discussão da sustentabilidade agrícola tem extrapolado o meio acadêmico, influenciando diferentes setores da sociedade, entre os 
quais destacamos: os consumidores, produtores rurais, pesquisadores, professores, estudantes e profissionais da extensão. Mesmo alguns setores do agronegócio, começam a fazer algumas experiências comerciais e produtivas nesta área (ex. Conway \& Barbier, 1990; Shiva, 1991; Altieri, 1992; Farshad \& Zinck, 1993; Billaud, 1995).

Como resultado, ainda que lenta e de forma subjacente, surgem no cenário nacional da pesquisa agropecuária e ensino universitário a discussão sobre o modelo agrícola vigente, os efeitos da "agricultura convencional" e a busca de alternativas para o meio rural (Graziano Neto, 1982; Silva, 1987; Bonilla, 1992; Kitamura, 1994; Paschoal, 1994; 1995; Weid, 1994; Ehlers, 1995; 1996; Romeiro, 1996; Almeida, 1997), simultaneamente surgindo as primeiras disciplinas de agroecologia e/ou agricultura orgânica em nível de graduação e de pós-graduação (Jesus, 1993; 1996; Paschoal, 1994).

Há muito debate sobre o modelo de desenvolvimento para o século XXI (Ruttan, 1991; Sachs, 1992), mas firma-se o conceito do ecodesenvolvimento, ou seja, um tipo de desenvolvimento que procura a harmonia da sociedade com a natureza (Sachs, 1992). Na agricultura, a busca é por um modelo que, sendo produtivo e rentável, seja ainda ambientalmente sadio e socialmente aceitável (Ikerd, 1993). Surgem, então, embates sobre quais as formas que satisfazem esses requisitos. Tal como na tipologia do pensamento ambientalista (Foladori, 2000), diferentes alternativas são defendidas.

A um cientista, reconhecer quando um sistema agrícola não é sustentável deve ser o ponto de partida. A dificuldade é definir exatamente o que seja sustentável. Lewandowski et al. (1999), interpretando vários autores, expressa que na atual interpretação do termo sustentabilidade, "qualquer definição de agricultura sustentável deve em princípio incluir tanto os aspectos ecológicos, como econômicos e sociais". Segundo Ikerd (1993), um sistema agrícola não é sustentável quando: (1) degrada sua produtividade e eventualmente perde sua habilidade produtiva por falhar na conservação $e$ proteção de seu recurso natural (sustentabilidade física); (2) não protege o ambiente, assim 
fazendo mais mal do que bem (sustentabilidade social) (3) não provém o povo de adequado suprimento de alimentos seguros e saudáveis por um preço compatível com a classe social (sustentabilidade política); (4) não é comercialmente competitiva, não gerando, pois, sobrevivência financeira ou aceitável qualidade de vida aos produtores (sustentabilidade econômica).

Se "a ciência não pode provar ou desaprovar a correição de qualquer filosofia" (Ikerd, 1993), os cientistas devem estar imbuídos em obter conhecimentos e desenvolver tecnologias que sejam benéficos para a sociedade. Este trabalho teve este propósito.

\section{2-4 - Enfoque sistêmico na pesquisa agropecuária}

Várias definições simples de sistema são propostas por diferentes autores. De início, todos estão de acordo em designar como sistema, uma inter-relação de elementos que constituem uma entidade ou unidade global.

Becht, citado por Hart (1980), depois de revisar vinte e quatro definições dadas na literatura para o termo sistema, usa a seguinte definição: "sistema é um arranjo de componentes físicos, um conjunto ou coleção de coisas, unidas ou relacionadas de tal maneira que formam um todo".

Existem dois aspectos importantes nessas definições: a interação de elementos/componentes e a unidade global/todo que resulta. As diferentes definições acentuam um ou outro aspecto. Para Bertalanffy (1975), o sistema é um conjunto de unidades em interação mútua, salientando o traço da globalidade/totalidade. Para este autor, o sistema é um todo que funciona como todo em virtude dos elementos que o 
constituem. Para Landriére (1984), um sistema "é um objeto complexo, formado por componentes distintos, ligados entre si por um certo número de relações".

Morin (1987) nota que um sistema não é necessária e nem principalmente composto por partes, alguns deles podem ser considerados conjuntos de estados, ou conjunto de acontecimentos, ou de reações. Ferdinand Saussure, citado por Morin (1987), associa aos caracteres comuns das definições precedentes, inter-relações e totalidade, uma terceira idéia, a de organização. Saussure define como sistema uma totalidade organizada, feita de elementos solidários que só podem definir-se uns em relação aos outros em função do lugar que ocupam nesta totalidade.

$\mathrm{Na}$ definição de sistema dada por Saussure a idéia de organização liga a idéia de totalidade e de inter-relação, tornando os três termos indissociáveis. As interrelações entre componentes (elementos, acontecimentos, individuos...) desde que tenham um caráter regular e estável tornam-se organizacionais e produzem o sistema (Morin, 1987).Entretanto, resta uma última noção a incorporar nessas diferentes definições: a de finalidade. Rosnay (1975) define um sistema como um conjunto de elementos em interação dinâmica, organizado em função de um objetivo. $O$ objetivo é atribuído pelo homem seu construtor e na natureza o objetivo é constatado a posteriori. Walliser, (1977), distingue a finalidade, propriedade revelada pelo comportamento dos sistemas (tudo se passaria como se ...) de intencionalidade, propriedade atribuida ou imposta a um determinado sistema por um centro de decisão.

Finalmente, pode-se afirmar que em um sistema, o conjunto de elementos ligados entre si por relações dinâmicas confere a ele uma organização com vistas a cumprir certos objetivos. Deste modo, um sistema é tanto um conjunto de elementos organizados como uma estrutura, e esta resulta das relações que asseguram o funcionamento do sistema. Em suma, pode-se afirmar que um sistema é uma estrutura finalizada (Jouve, 1986). 
O termo genérico sistemas agrícolas é usado para designar o conjunto de noções e conceitos correspondentes aos niveis de organização da atividade de produção agrícola (Mazoyer, 1985; Deffontaines, 1988). A cada nível organizacional, é designado um termo que é igualmente o conceito de funcionamento deste nível e que corresponde, em primeira aproximação, a unidades territoriais particulares (Jouve, 1986), ou centros de decisão (Bourgeois, 1983 ).

Desta maneira, distinguem-se três níveis:

a) Do processo produtivo - é onde se observa e se deduz os mecanismos biológicos, de intervenção dos equipamentos e das técnicas, ou seja as parcelas cultivadas e os rebanhos;

b) Do estabelecimento agrícola e da família - que diz respeito à combinação, no sentido exato da palavra, de processos produtivos, que devem ser compreendidos em relação ao trabalho disponível e mobilizado, ao capital, aos resultados quantitativos e qualitativos do conjunto da atividade das pessoas envolvidas;

c) De abrangência da região - que comporta a atividade econômica à jusante e à montante dos níveis precedentes.

O estabelecimento agrícola está no centro de toda reflexão e procedimento de diagnóstico, pois é onde se dá o processo de artificialização do ecossistema e é a célula básica do processo de produção agrícola (Dumazert \& Lévard, 1987): é o lugar onde se intercruzam elementos biotécnicos e sócio-econômicos, sob a direção de um centro de decisão, o agricultor e sua família (Bourgeois, 1983; Dufumier, 1985; Sautter, 1985); é onde se hierarquizam os problemas técnicos (Sebillotte, 1979) e se refletem as iniciativas de desenvolvimento comandadas ao nível do sistema socioeconômico envolvente. 
Nos diferentes conceitos apresentados é visível a preocupação em não se estabelecer um "pacote tecnológico" da agricultura sustentável, dado o seu caráter holístico e multidisciplinar. Defende-se que a sustentabilidade só pode ser atingida mediante a consideração do enfoque sistêmico de produção, abolindo de forma sumária a uniformização de técnicas e o emprego de fórmulas pré-estabelecidas e genéricas de manejo (Fancelli, 1994). No momento, todos parecem concordar que a agricultura sustentável é ainda um anseio; o que varia é a expectativa em relação ao grau das mudanças contidas nesse objetivo e, conseqüentemente, seu prazo de estabelecimento (Ferraro Jr., 2000).

\section{2-5 - Comercialização de produtos orgânicos}

No final da década de 80 começam as primeiras iniciativas de comercialização em maior escala de produtos orgânicos, Antes disso, já vinha ocorrendo, e continua até hoje, a venda em feiras específicas nas grandes cidades brasileiras (Cerveira \& Castro, 1999), seja através de sistemas cooperativos ou diretamente dos produtores aos consumidores.

Invariavelmente o consumidor é um indivíduo das classes de mais posses, que pode aliar o poder aquisitivo a uma maior consciência sobre as questões ambientais e mais zelo quanto à qualidade dos alimentos. $\mathrm{O}$ grande desafio é desenvolver sistemas produtivos que possam tornar abundantes produtos de qualidade no prato do brasileiro, paralelamente criando consciência na população sobre a preservação ambiental e da própria saúde.

Nestes últimos anos, o consumo de alimentos ditos "orgânicos" têm crescido rapidamente em todo planeta, especialmente nos países de maior desenvolvimento econômico, e aos poucos cresce no Brasil (Cerveira \& Castro, 1999; Charity, 1999; Harkaly, 1999; Melo, 2000). A produção procura atender esse mercado, como também o externo, especialmente exportando café, soja e açúcar orgânico (Harkaly et al., 1997; 
Harkaly, 1999; 2000; Buzzanell, 2000; Osterroht, 2000). Nesse mercado externo, pode crescer um outro produto, o de sucos e frutas cítricas, cuja produção brasileira é ainda incipiente (Laux, 1999).

Em 1995 teve início, no Estado de São Paulo, a comercialização de produtos orgânicos nos supermercados. $O$ sucesso nas vendas permitiu identificar um mercado latente, pois a demanda potencial por estes produtos tornou-se visível (Dulley et al, 2000).

O fato do mercado mundial de produtos orgânicos estar crescendo aceleradamente nos últimos anos, não pode ser analisado apenas do ponto de vista da participação do setor dentro do mercado internacional de alimentos. Em um trabalho realizado junto aos produtores orgânicos da região da Campania, na Itália, Cembalo (2000) reitera a importância do desenvolvimento de novos sistemas de produção que promovam a preservação do meio ambiente, gerando também uma alimentação mais segura.

Cicia et al (1998), coloca que a abertura de novos mercados para os produtos orgânicos é fundamental, mas que não pode estar dissociada da organização da propriedade rural e da definição de políticas públicas que além de visar o retorno econômico para os produtores orgânicos, que têm obtido preços mais vantajosos para os seus produtos, beneficiem a população como um todo, levando em conta os aspectos sociais e ambientais. 


\section{3- MATERIAL E MÉTODOS}

$\mathrm{O}$ estudo procurou obter informações in loco, ao longo de três anos, mantendo um permanente intercâmbio de opiniões e informações com os produtores participantes. Pelo fato dos dados técnicos e econômicos terem sido colhidos em anos de crise no setor citrícola, o manejo, especialmente das pequenas propriedades foi bastante influenciado pela restrição de recursos e incentivo para práticas agrícolas que implicassem em uma elevação dos custos de produção.

No processo de levantamento de dados para esta dissertação, buscou-se atuar através do enfoque sistêmico e de uma postura técnico-pedagógica de mão dupla, entre agricultor-pesquisador, através de um permanente diálogo, respeito e registro de todas as considerações advindas dos produtores, corpo técnico e trabalhadores rurais envolvidos nas propriedades acompanhadas e demais entidades e instituições atuantes nas áreas em questão.

Por abranger um número de variáveis bastante amplo e também pelo fato dos pomares acompanhados e analisados situarem-se em propriedades com tradição no cultivo de citros, os resultados obtidos contaram, fundamentalmente, com a participação efetiva dos produtores, representando um campo bastante promissor para a abordagem: diagnóstico/ análise/ discussão participativa/indicativos de intervenção.

\subsection{Definição da área de abrangência da pesquisa}

Em 1997, no momento de se definir a área de atuação da presente pesquisa, ficou patente a necessidade de escolher uma cultura cuja cadeia produtiva abrangesse tanto a comercialização in natura quanto o processamento agroindustrial localizados num raio de até $80 \mathrm{~km}$ das bases de referência deste trabalho (Araras, Piracicaba e São Carlos), levando em conta os custos financeiros da atividade e o tempo disponível para o levantamento de dados e acompanhamento das propriedades. 
De acordo com a divisão estabelecida pela Secretaria da Agricultura e Abastecimento do Estado de São Paulo, a área em questão abrange duas sedes regionais: a Regional de Araraquara e a Regional de Limeira.

A Regional de Araraquara conta com 16 municípios, sendo que por ocasião da pesquisa foram envolvidos os municípios de Descalvado e São Carlos. A Figura 1 apresenta o mapa da região acima mencionada.

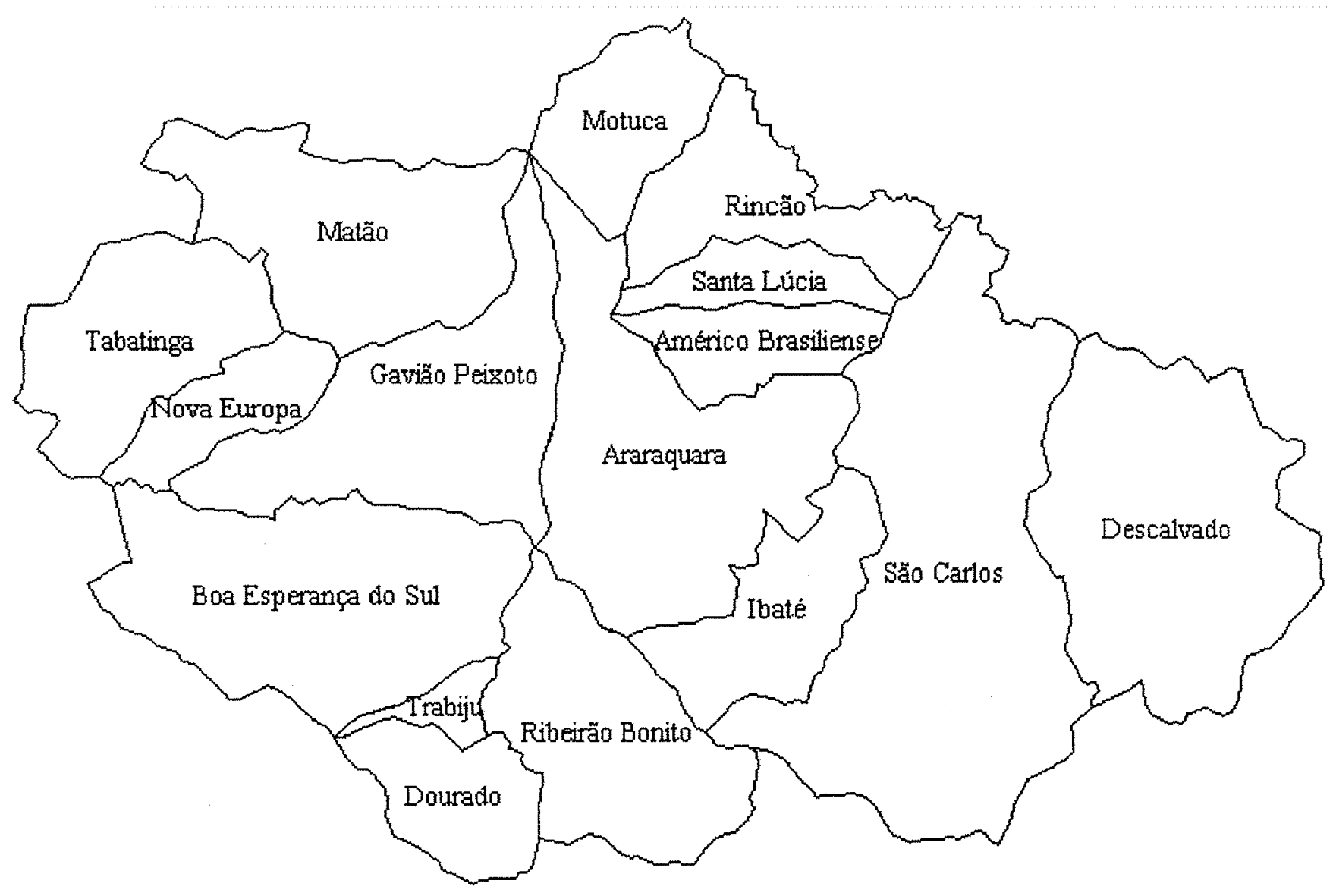

Figura 1: Regional de Araraquara da Secretaria da Agricultura e Abastecimento do Estado de São Paulo. 
A Regional de Limeira conta com 13 municípios, sendo que por ocasião da pesquisa foram envolvidos os municípios de Itirapina e Rio Claro. A Figura 2 apresenta o mapa da região acima mencionada.

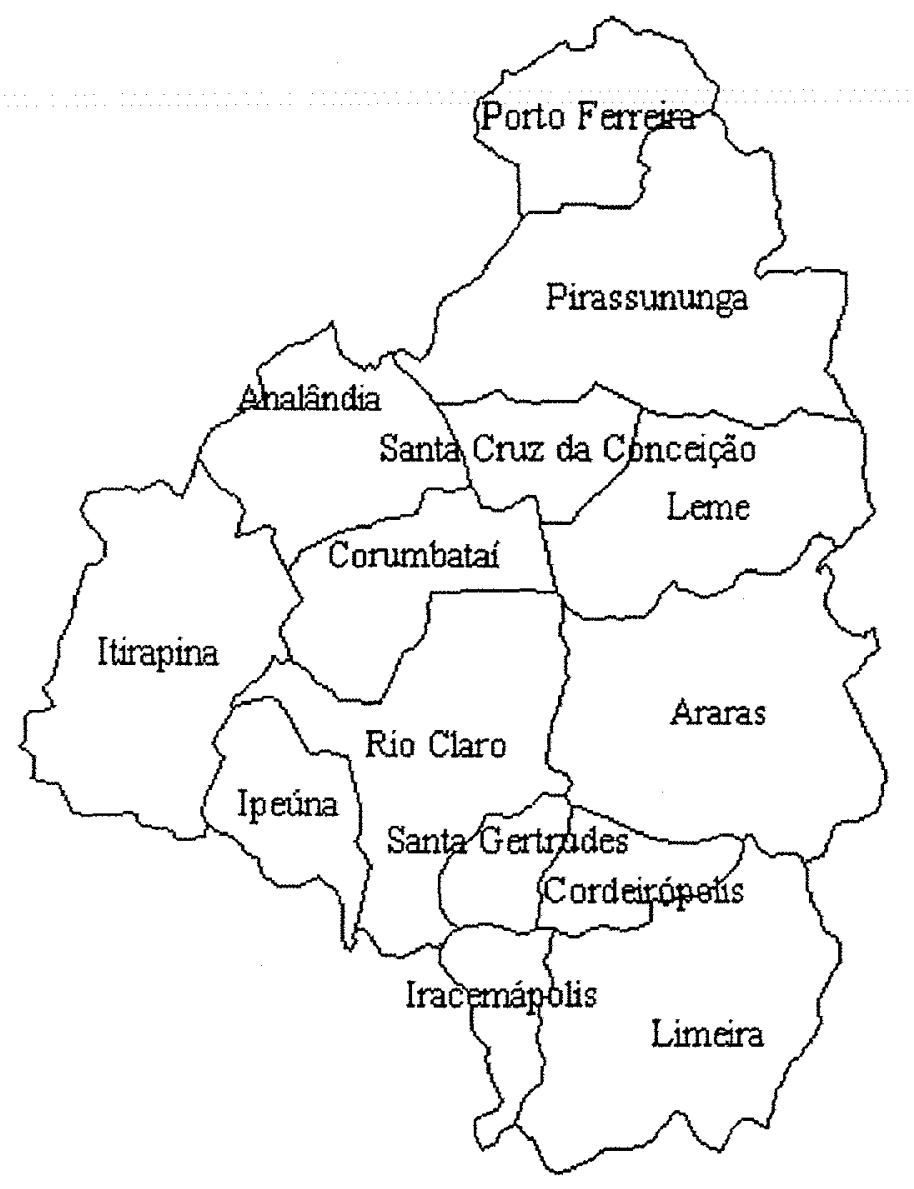

Figura 2: Regional de Limeira da Secretaria da Agricultura e Abastecimento do Estado de São Paulo. 
3.2 Escolha das cinco propriedades para o estudo de caso

Foram analisadas cerca de 12 propriedades rurais da região central do Estado de São Paulo. Dentre elas foram selecionadas cinco propriedades que melhor atenderam aos seguintes requisitos:

- estar com a propriedade rural em plena produção;

- ter na citricultura uma das atividades produtivas principais;

- disposição em fornecer as informações necessárias para o trabalho de pesquisa.

As cinco propriedades definidas foram:

\section{Sítio Pinhalzinho (A) - Benedito Fernando Brisolari}

ÁREA: 19,25 ha - MUNICÍPIO: São Carlos - SP

PÉS DE CITROS PLANTADOS: 470 .

ROTEIRO DE ACESSO: Estrada do Broa, sentido São Carlos - Itirapina, km 4,5 à esquerda, andar cerca de $3 \mathrm{~km}$ de terra até o Sítio, entrada à esquerda.

\section{Sítio Cachoeirinha (B) - Antonio Corrocher}

ÁREA: 13,5 ha - MUNICIPIO: Rio Claro - SP

PÉS DE CITROS PLANTADOS: 1.750 pés.

ROTEIRO DE ACESSO: Estrada Rio Claro - Ajapi, sentido Ajapi, Bairro Cachoeirinha, propriedade ao lado da sede do bairro (Igreja e Centro Comunitário)

\section{Sítio Lagoa Grande (C) - Virgínia Maria Batistela Chiaradia}

ÁREA: 38,5 ha - MUNICÍPIO: Rio Claro - SP

PÉS DE CITROS PLANTADOS: 3.100 .

ROTEIRO DE ACESSO: Estrada Rio Claro - Ajapi, sentido Ajapi, Bairro Cachoeirinha, $\mathrm{km} 05$

\section{Fazenda do Haras (D) - George Fernando Hoffmann}

ÁREA: 445,9 ha - MUNICÍPIO: Descalvado - SP

PÉS DE CITROS PLANTADOS: 32.800 .

ROTEIRO DE ACESSO: Estrada São Carlos - Descalvado (SP-255), acesso à direita após a Mineração Jundu, $3 \mathrm{~km}$ de estrada de terra.

\section{Fazenda Raio de Sol (E) - Edmundo Eugênio Archelós Blasco}

ÁREA: $1.430,0$ ha - MUNICÍPIO: Ititrapina - SP

PÉS DE CITROS PLANTADOS: 476.000.

ROTEIRO DE ACESSO: Estrada Analândia a Itirapina (SP-225), acesso à direita após viaduto sobre a Rodovia Washington Luiz (SP-310) 


\subsection{Definição das informações a serem colhidas}

Dentro do conceito de analisar a propriedade com um todo, através do enfoque sistêmico, foram destacados alguns pontos principais a serem acompanhados em cada uma das propriedades:

- comercialização;

- cultivares utilizadas;

- diversificação e rotação de culturas;

- manejo de pragas, patógenos e plantas invasoras;

- manejo e conservação da água e do solo;

- nutrição de plantas;

- rentabilidade;

- utilização de máquinas e implementos;

- utilização de matéria orgânica;

Dentre estes pontos, quatro aspectos básicos serviram de referência para a pesquisa nos cinco agroecossistemas acompanhados neste estudo:

A) Aspetos geográficos e socioeconômicos: incluiu-se a descrição dos recursos naturais a um nível superior de onde os agroecossistemas se encontram, região fisiográfica, ou seja, hidrologia, topografia, geologia e solos, vegetação original, clima, etc. Os aspectos sócio-econômicos abrangeram o tamanho da propriedade, posse da terra, evolução dos preços, produção e rendimentos dos produtos dos agroecossistemas, características da mão-de-obra, etc. 
B) Aspectos agronômicos: correspondeu à descrição físico-biológica dos agroecossistemas. A análise agronômica incluiu uma descrição sucinta de todo o processo de produção e dos componentes do mesmo.

C) Análise do impacto ambiental: correspondeu à identificação dos pontos de degradação ambiental nos agroecossistemas e os fatores que estão afetando a sustentabilidade dos mesmos.

$\mathrm{Na}$ análise foram selecionados talhões nas diferentes propriedades, todos plantados com laranja pera (Citrus sinensis (L.) Osbeck), com população média nos talhões de 304,38 plantas/hectare.

Foi realizado um levantamento a campo de todo o sistema de produção adotado por cada agricultor, seguido de pesquisa e análise dos dados secundários disponíveis na literatura referentes à citricultura na região de São Carlos-SP.

Procedeu-se a definição e dimensionamento do módulo a ser monitorado em cada propriedade que variou de 1,00 hectare na menor propriedade ate 10,01 hectares na propriedade de maior porte.

Na propriedade A o acompanhamento foi realizado em um talhão de 1,0 hectare, em NEOSSOLO FLÚVICO Eutrófico; na propriedade B foi selecionado um talhão de 1,0 hectare, de ARGISSOLO VERMELHO-AMARELO Eutrófico típico; na propriedade $\mathrm{C}$ foi acompanhado um talhão de 2,4 hectares, também com ARGISSOLO VERMELHO-AMARELO Eutrófico típico; na propriedade D foi acompanhado um talhão 
de 10,00 hectares de LATOSSOLO VERMELHO-AMARELO Eutrófico e na propriedade E o talhão selecionado foi de 10,01 hectares em ARGISSOLO VERMELHO-AMARELO Distófico típico, com manchas de NEOSSOLO QUARTZARÊNICO Órtico.

A idade das plantas, em relação ao início do estudo, variou entre plantios realizados nos anos de 1988 a 1992, portanto sendo consideradas como em período estável de produção. Os talhões foram submetidos a análises de solo anuais. As amostras de solo foram compostas de 10 subamostras, coletadas nas áreas livres ou nas entrelinhas dos pomares.

\subsection{Análise dos custos de produção}

Foi realizado um levantamento dos custos de produção e dos ingressos brutos, a partir dos quais foram determinadas as margem bruta e o ingresso líquido de receitas.

Embora cada propriedade tenha utilizado um manejo distinto para a produção citrícola, para efeito da determinação dos custos de produção, foram utilizadas planilhas que tentaram abranger todo o universo de receitas e despesas referentes a cada safra.

É importante destacar que a apresentação dos dados trata-se de uma síntese dos custos e receitas acompanhados nas três últimas safras, que têm como parâmetro os dados apresentados no AGRIANUAL/99, adaptados para a safra 99/2000, sempre levando em conta as condições de fertilidade dos solos existentes em cada uma das 05 propriedades.

${ }^{1}$ À classificação de solo existente foi dada a nova nomenclatura, segundo EMBRAPA/Solos (1999). 
Tabela 1- Resumo dos custos de produção por hectare, em R\$, na região de Araraquara, referentes ao ano de 2000, valores corrigidos para janeiro/2001 (AGRIANUAL,1999).

\begin{tabular}{|l|c|c|}
\hline Itens & $\mathbf{1 9 9 9 / 0 0}$ & $\mathbf{\%}$ \\
\hline Operações mecaniz. & 861,78 & - \\
\hline Operações manuais & $1.282,55$ & - \\
\hline Total operações (somando-se as duas anteriores) & $2.144,33$ & 49,97 \\
\hline Insumos & $1.540,32$ & 35,89 \\
\hline Administ./Comercialização & 606,83 & 14,14 \\
\hline Custo total/ha/ano & $4.291,48$ & - \\
\hline Receita bruta/ha/ano & $4.977,00$ & - \\
\hline Receita liquida/ha/ano & 685,52 & - \\
\hline
\end{tabular}

* Em relação ao custo total. 


\section{4- RESULTADOS E DISCUSSÃO}

\subsection{Dados referentes à propriedade $\mathrm{A}$}

Trata-se de uma pequena propriedade oriunda do parcelamento da antiga Fazenda Pinhal, célula mater do município de São Carlos - SP. Foi adquirida em 1975 por Benedito Fernando Brisolari, que removeu uma parte da mata original que cobria a área e implantou as culturas de café e citros. Com as sucessivas geadas e a queda dos preços do café, erradicou a cultura cafeeira e passou a se dedicar à horticultura e à produção de leite, a partir de 1980. Manteve essas atividades até 1992, quando passou a cultivar mandioca e implantou uma quadra de tangerina ponkan, nas áreas onde desativou a horticultura. Em 1998, quando já estava em andamento a pesquisa, podou os pés de ponkan de um talhão antigo com cerca de 15 anos e começou a reduzir a produção leiteira.

No final de 2000 , em face dos baixos preços do leite e dos citros, erradicou parte do talhão de citros acompanhado na pesquisa, vendeu todo o rebanho bovino e arrendou a área produtiva da propriedade (18,0 ha), permanecendo apenas com uma quadra de ponkan e as benfeitorias residenciais do sítio.

\subsubsection{Descrição da propriedade A}

- Proprietário: Benedito Fernando Brisolari

- Principais Atividades Econômicas: citricultura e gado de leite

- Propriedade: 19,25 ha

- Localização: Sítio Pinhalzinho

- Relevo: meia encosta, tendo ao fundo o Ribeirão do Pinhal

- Situação legal de posse: proprietário.

- Distribuição das áreas na propriedade:

Benfeitorias: casa principal $220 \mathrm{~m}^{2}, 2$ casas com $120 \mathrm{~m}^{2}$ e rancho $150 \mathrm{~m}^{2}$

Pastagens: 15,0 ha de Brachiaria decumbens e Brachiaria brizantha 
Produção vegetal: 0,5 ha de cana e 2,5 ha de citros

- Fontes de energia: elétrica, trifásica com transformador de $30 \mathrm{KVA}$

Infra-estrutura produtiva:

-Máquinas: 1 trator (Massey Ferguson 275 X)

-Implementos: 1 arado, 1 grade niveladora, 1 cultivador, 1 plantadeira de 3 linhas, 1 carreta de 2 rodas e uma picadeira estacionária

-Curral com estábulo coberto para ordenha

-Paiol: 01 e 03 caixas cobertas para armazenar trato para o gado com $6 \mathrm{~m}^{3}$ cada.

Água

- Área passível de irrigação por gravidade: 5,0 ha

- Origem: nascente que abastece represa e é afluente do Ribeirão do Pinhal

Solos:

- Classificação: NEOSSOLO FLÚVICO Eutrófico e ARGISSOLO VERMELHOAMARELO Eutrófico.

- Análise química: resultados expressos na Tabela 7

- Calagem: foram colocados 0,5 toneladas de calcário dolomítico por hectare na safra $97 / 98$

- Adubação: no pomar de citros - duas vezes por ano com $200 \mathrm{~g}$ de NPK 20-05-20 por pé.

- Drenagem: boa drenagem, não tem problemas com erosão

- Cobertura vegetal original: campo cerrado, cerradão e mata ciliar

- Manejo de invasoras: roçadeira e carpa.

- Presença de cupins e formigas: combate formigas com iscas granuladas

- Utilização de Matéria Orgânica: no pomar, esterco bovino 20 toneladas por hectare e na cana fertirrigação com chorume 
- Matéria Orgânica toda produzida na propriedade

- Utilização de cobertura morta/viva: utiliza capim picado e palha no pomar, após adubação orgânica

- Plantio em nível/terraços: tanto no pomar, como na cana

- Utilização de agrotóxicos: para controle do ácaro da leprose

- Sintomas de deficiência nutricional - ausência de sintomas

-Práticas de controle fitossanitário: utilização de doses de inseticidas, quando necessário.

Pomar de citros: 2,5 hectares

- Culturas e variedades: laranja (pera-rio) e ponkan

- Consorciação: plantio de milho-verde nas entrelinhas das quadras mais novas de ponkan

\section{- Comercializacãa}

- Venda dos produtos para sacolões e varejões da cidade de São Carlos.

- Transporte: através de caminhonete D-20

\section{Mão de Obra}

- Número de Pessoas: 01 (apenas o proprietário), os filhos trabalham fora. Até 1997 mantinha 01 funcionário.

- Disponibilidade de mão de obra na região: encontra-se com facilidade, mas em geral não é de boa qualidade.

- Períodos de ociosidade: ausente

\section{- Administração:}

- Forma de contabilidade: anota os gastos

- Fontes de renda: pomar, milho verde, leite e venda de cana na seca; aluguel de 01 casa no próprio sítio (1 salário mínimo por mês) e 01 casa na cidade $(\mathrm{R} \$ 400,00)$ 
- Percentagem da renda agrícola sobre o total: $50 \%$ agrícola e $50 \%$ não agrícola; a partir de 2001, arrendou a área produtiva por 2 salários mínimos mensais e vendeu todo o gado.

- Intenção/possibilidade de ampliação das atividades: não tem pretensões de voltar a produzir intensivamente.

- Formas de orientação técnica que recebe: filho mais velho é auxiliar de veterinário, auxiliava nos partos e aplicação de medicamentos do rebanho bovino quando necessário.

\subsubsection{Custos de produção da propriedade A}

A comparação entre os custos de produção dos cinco diferentes sistemas de produção citrícola estudado, com os custos médios da citricultura praticada na região central do Estado de São Paulo pode ser feito através da análise das tabelas de 1 a 6 .

A propriedade A emprega regularmente esterco de curral, um insumo relativamente caro, sendo também dispendiosa a sua distribuição no pomar. Isso leva a um alto custo de produção, praticamente não lhe deixando renda líquida (tabela.2). Entretanto, esse esterco é um subproduto da bovinocultura de leite, razão pela qual o proprietário não contabiliza em seus custos de produção a distribuição de 20 toneladas/ano/hectare de esterco no pomar.

\subsection{Dados referentes à propriedade B}

O proprietário do Sítio Cachoeirinha, Antônio Corrocher, é da terceira geração da família Corrocher, estabelecida na região do Córrego Cachoeirinha. Há 15 anos adquiriu junto com os irmãos esta área de 13,5 hectares. Implantou pomar de citros e a horticultura como atividades para manutenção da família.

Atualmente a renda principal vem da produção de hortaliças, que a partir de 1999 passou a ser conduzida dentro das norma da Agricultura Orgânica. Até 
fevereiro de2001 deve estar com a produção de hortaliças certificada pela Associação de Agricultura Orgânica, de São Paulo.

Tabela 2 - Resumo dos custos de produção por hectare, em $R \$$, na propriedade $A$, referentes às safras 97/98, 98/99 e 99/00, valores corrigidos para janeiro/2001.

\begin{tabular}{|l|c|c|c|c|c|c|}
\hline Itens & $\mathbf{1 9 9 7 / 9 8}$ & $\mathbf{\% *}$ & $\mathbf{1 9 9 8 / 9 9}$ & $\mathbf{\%}$ & $\mathbf{1 9 9 9 / 0 0}$ & $\mathbf{\%}$ \\
\hline Operações mecaniz. & 503,24 & - & 426,71 & - & 457,47 & - \\
\hline Operações manuais & 541,84 & - & 434,30 & - & 618,45 & - \\
\hline $\begin{array}{l}\text { Total oper. (soma das duas } \\
\text { anteriores) }\end{array}$ & $1.045,08$ & 37,80 & 861,01 & 39,10 & $1.075,92$ & 50,00 \\
\hline Insumos & $1.578,31$ & 57,00 & $1.221,23$ & 55,50 & $1.020,14$ & 44,50 \\
\hline Administ./Comercialização & 144,33 & 5,20 & 118,99 & 5,40 & 195,56 & 8,50 \\
\hline Custo total/ha/ano & $2.767,72$ & - & $2.201,95$ & - & $2.291,62$ & - \\
\hline Receita bruta/ha/ano & $2.462,10$ & - & $2.378,95$ & - & $2.444,49$ & - \\
\hline Receita líquida/ha/ano & $-305,62$ & - & 177,76 & - & 152,87 & - \\
\hline
\end{tabular}

* Em relação ao custo total.

No pomar ainda mantém o manejo convencional, por falta de preço para os citros. Fundou, juntamente com mais doze produtores vizinhos a Associação de Hortifrutigranjeiro Vale Verde de Rio Claro, sendo seu atual presidente.

\subsubsection{Descrição da Propriedade B}

- Proprietário: Antonio Corrocher

- Principais atividades conômicas: citricultura, horta e milho-verde

- Propriedade: 13,5 ha

- Localização: Sítio Cachoeirinha

- Relevo: meia encosta, tendo ao fundo o Córrego Cachoeirinha

- Situação legal de posse: proprietário. 
- Distribuição das áreas na propriedade:

Benfeitorias: casa $180 \mathrm{~m}^{2}$, rancho $180 \mathrm{~m}^{2}$

Pastagens: 0,5 alqueire

Produção vegetal: 1 alqueire de horta; 2 alqueires de milho e 2,5 alqueires de pomar

- Fontes de energia: elétrica, trifásica com transformador de $30 \mathrm{KVA}$

Infra-estrutura produtiva:

-Máquinas: 2 tratores (Massey Ferguson 50 X, 275 X)

-Implementos: 1 arado, 1 grade niveladora, 1 cultivador, 1 plantadeira, 1 encanteiradeira, 1 pulverizador

Água

- Área irrigada: 01 alqueire

- Origem: nascente que abastece o Córrego Cachoeirinha

- Análise da água de irrigação e lavagem de verduras (Anexo C - Tabela C1).

Solos:

- Classificação: argissolo vermelho-amarelo eutrófico

- Análise química: resultados apresentados nas tabelas

- Calagem: na última calagem, em 1999, foram gastos 18 toneladas para toda a propriedade.

- Drenagem: boa, porém apresenta vestígios de erosão laminar, principalmente na horta

- Cobertura vegetal anterior: pastagem e eucalipto

- Manejo de invasoras: raramente aplica herbicidas a base de glifosato; normalmente só capina manual e cobertura morta

- Presença de cupins e formigas: problemas com saúvas (utilizava iscas granuladas, atualmente apenas controles físicos e fungos) e formigas lava pé (utiliza cal virgem)

- Preparo do solo: arado/grade; horta/encanteiradeira; pomar/grade

- Utilização de Matéria Orgânica: cama de frango para todas as atividades. 
- Matéria Orgânica produzida na propriedade: utiliza esterco do gado e capim, para compostagem

- Matéria Orgânica de origem externa: aproximadamente 10 ton/mês de cama de frango.

- Utilização de cobertura morta/viva: utiliza capim picado e bagaço de cana na horta; quando há disponibilidade utiliza poda triturada de árvores urbanas, fornecida gratuitamente pela Prefeitura de Rio Claro.

- Plantio em nível/terraços: curvas de nível no pomar/ na horta procura deixar capim nas curvas como método de conservação.

- Adubação Verde: fez algumas experiências no pomar, com mucuna preta, feijão de porco e tremoço plantados nas entrelinhas.

- Quebra-ventos: eucalipto

- Utilização de Adubação Química: no pomar tem utilizado NPK 20-05-20 e 12-06-12. Complementação com uréia

- Utilização de agrotóxicos: iscas para moscas de fruta e acaricidas.

Pomar: 6,0 hectares

- Culturas e variedades: laranja (pera-rio e lima) e ponkan

- Consorciação/Rotação: plantio de milho verde nas entrelinhas

\section{Comercialização}

- Como planeja a produção: a cada 15 dias, semeia um novo canteiro na horta; colhe e entrega à medida em que a demanda aumenta ou há requisição.

- Realiza algum tipo de processamento ou transformação na propriedade? comercializa os produtos da horta in natura através de caixas.

- Formas de comercialização e arrecadação mensal de cada uma: feiras e varejões, obtendo renda média de 4 salários mínimos (lucro líquido)

- Problemas com comercialização: concorrência com produtos de Leme, Araras e Cordeirópolis, cujos horticultores entregam com preço muito baixo, em Rio Claro

- Transporte: através de um caminhão F-4000 


\section{Mão de Obra}

- Número de pessoas: Família: 04 Contratada: 0

- Disponibilidade de mão de obra na região: não sabe

- Vínculo empregatício: mão de obra familiar (pai, tio e dois irmãos), recolhem INSS como autônomos

- Períodos de ociosidade: ausente

- Administração:

- Forma de contabilidade: anota os gastos

- Fontes de Renda: pomar, horta, milho (a horticultura representa, atualmente, 85\% da renda familiar)

- Percentagem da renda agrícola sobre o total: $100 \%$

- Intenção/possibilidade de ampliação das atividades: Há possibilidade de ampliação de qualquer atividade; havendo o aumento da demanda, aumenta-se a produção através da ampliação da área cultivada.

- Formas de orientação técnica que recebe (ou que gostaria de): Atualmente não recebe assistência técnica e gostaria da orientação de um Engenheiro Agrônomo

\subsubsection{Custos de produção da propriedade B}

A propriedade B empregou cama de frango na safra $97 / 98$, visto que este era um hábito do produtor desde a implantação do pomar. Na medida em que os custos do insumo (comprado) passam a representar um percentual muito alto no sistema ele deixa de usar a cama de frango. Desta forma, a propriedade B, na safra 97/98, teve um custo de produção mais elevado em relação aos anos seguintes (tabela.3). Mesmo assim teve um custo final menor do que a propriedade $A$, sendo menos da metade nas duas outras safras, obtendo, assim, uma rentabilidade muito maior. 
Tabela 3 - Resumo dos custos de produção por hectare, em $R \$$, na propriedade $B$, referentes às safras 97/98; 98/99 e 99/00, valores corrigidos para janeiro/2001.

\begin{tabular}{|l|c|c|c|c|c|c|}
\hline Itens & $1997 / 98$ & $\% *$ & $1998 / 99$ & $\%$ & $1999 / 00$ & $\%$ \\
\hline Operações mecanizadas & 418,23 & - & 298,43 & - & 310,86 & - \\
\hline Operações manuais & 613,90 & - & 463,84 & - & 603,75 & - \\
\hline Total oper. & $1.032,13$ & 57,20 & 762,27 & 77,30 & 914,61 & 84,40 \\
\hline Insumos & 674,93 & 37,50 & 137,94 & 14,00 & 82,71 & 7,60 \\
\hline Administ./Comercialização & 94,91 & 5,30 & 86,02 & 8,70 & 86,58 & 8,00 \\
\hline Custo total/ha/ano & $1.801,97$ & - & 986,23 & - & $1.083,90$ & - \\
\hline Receita bruta/ha/ano & $3.163,55$ & - & $2.457,84$ & - & $1.731,60$ & - \\
\hline Receita líquida/ha/ano & $1.361,68$ & - & $1.471,61$ & - & 647,70 & - \\
\hline
\end{tabular}

* Em relação ao custo total.

\subsection{Dados referentes à propriedade C}

O Sr. Antônio Chiraradia, marido de D. Virgínia, dedicava-se ao ramo atacadista na CEAGESP, em São Paulo. Há cerca de 20 anos vendeu sua parte na sociedade da qual fazia parte e adquiriu esta área de 38,5 hectares em Rio Claro. Nos últimos cinco anos, o Sr. Antônio foi acometido de uma série de problemas gástricos, tendo sido submetido a duas cirurgias, em São Paulo. A partir de então D. Virgínia assumiu a administração da propriedade, sendo que os filhos há muitos anos já não residem no sítio.

A atividade produtiva concentra-se nos pomares, sendo a maior parte de citros, no cultivo de grãos e na horticultura. A proprietária tem enfrentado dificuldades em manter a atividade produtiva do sítio, sendo que a queda das receitas com a citricultura têm levado a pensar em parar com essa atividade.

\subsubsection{Descricão da propriedade C}

- Proprietária : Virgínia Maria Batistela Chiaradia

- Principais atividades econômicas: citricultura, horticultura e milho 
- Propriedade: Sítio Lagoa Grande - com área total de 38,5 hectares

- Relevo: meia encosta, tendo ao fundo o Córrego Cachoeirinha

- Situação legal de posse: da proprietária

- Distribuição das áreas na propriedade:

Benfeitorias: : rancho, $120 \mathrm{~m}^{2}$, casas, $70 \mathrm{~m}^{2} \mathrm{e} 144 \mathrm{~m}^{2}$

Mata ciliar: 1,3 hectares

Produção vegetal: 2,5 hectares de horta; 6 hectares de milho e 7,0 hectares de alqueires de pomares

- Fontes de energia: elétrica, com transformador de $30 \mathrm{KVA}$

Infra-estrutura produtiva:

- Máquinas: Trator Valmet 80 e 1 caminhão Chevrolet, ano 1974

- Implementos: Pulverizador (2), roçadeira (1), rotativa (1), grade aradora (1), frade niveladora(1), arado (1) e cultivador antigo (1)

- Material de Irrigação: aspersão convencional na horta, 1 motor diesel e 2 motores elétricos

- Galpão: 1 para guardar máquinas e implementos, com $120 \mathrm{~m}^{2}$

- Moradia proprietário: 2 casas

- Moradia trabalhadores: 1 casa para caseiro (vazia)

- Outros: 1 casa para com produção de cogumelos, utilizada por um genro

Água:

- Análise de água de irrigação e lavagem de verduras ( Anexo C - Tabela C1) .

Solos:

- Classificação: ARGISSOLO VERMELHO-AMARELO Eutrófico

- Análise química: resultados apresentados nas tabelas

- Calagem: 1997 e 1998 em partes da propriedade 
- Drenagem: boa, problemas com água proveniente da propriedade vizinha

- Cobertura Vegetal atual/maneja de invasoras: herbicida a base de glifosato 1 a 2 vezes por ano.

- Presença de cupins e formigas: formiga - saúva (horta e laranja) utiliza iscas granuladas

- Preparo do solo: arado e grade

- Utilização de Matéria Orgânica: cama de frango para horta

- Quantificação da Matéria Orgânica produzida na propriedade: não produz

- Matéria Orgânica de origem externa: 4,0 tonelada por mês de cama de frango

- Utilização de cobertura morta/viva: utiliza cobertura morta (bagaço de cana)

- Plantio em nível/terraços: milho plantado em curva de nivel

- Adubação verde: não utiliza

- Quebra ventos: inexistente

- Erosão: vestígios de erosão laminar

- Compactação/Adensamento: pomar cítrico

- Adubação química: NPK 04-14-08

- Já utilizou agrotóxicos? (tipo): laranja - Dicofol e horta- Decis (somente se preciso) e calda de fumo

\section{$\underline{\text { Pomar }}$}

- Culturas e variedades: laranja pera, ponkan, morcote, mexirica do rio, manga, abacate, lixia e acerola ( área pequena e mista).

- Consorciação/rotação: não utiliza

- Sintomas de deficiência nutricional: laranja apresenta sintomas de deficiência de nitrogênio e potássio.

- Problemas fitossanitários e época: laranja - lepra e broca; abacate com antracnose

- Práticas de controle fitossanitário: atualmente não 


\section{Comercialização}

- Como planeja a produção: plantio de acordo com a época e também com as espécies mais demandadas.

- Realiza algum tipo de processamento ou transformação na propriedade? Somente coloca a produção em caixas, vendendo nas feiras e varejões

- Formas de comercialização e arrecadação mensal de cada uma: através de caixas de plástico (horta, pomar e milho). Está tendo prejuízo.

- Problemas com comercialização: concorrência com produtos de foram (Ceasa e Cidades vizinhas); estão sobrando produtos (não consegue vender), em parte devido a baixa qualidade da produção

- Transporte de produção: caminhão

\section{Administração :}

- gastos elevados com manutenção de máquinas e implementos (óleo, graxa, consertos)

- Número de pessoas: Família : 2 (casal) Contratada: 1

- Disponibilidade de mão de obra na região: considera alto custo

- Vínculo empregatício: 1 diarista

- Períodos de ociosidade: não

- Forma de contabilidade: não tem

- Análise de custos: não faz

- Fontes de renda: pomar, horta e milho e aposentadoria Sr. Antônio

- Percentagem da renda agrícola sobre o total: 50\% produção agrícola e $50 \%$ aposentadoria

- Intenção/possibilidade de ampliação das atividades: sim, somente se a demanda aumentar e aparecerem soluções para seus problemas

- Formas de orientação técnica que recebe (ou gostaria): não recebe, e está necessitando urgentemente de um Engenheiro Agrônomo. 


\subsubsection{Custos de produção da propriedade C}

A propriedade $\mathrm{C}$ teve um custo de produção bastante reduzido, em função de utilizar tratos culturais mínimos, especialmente na última safra, o que a levou a ter os menores custos de todas as propriedades estudadas (tabela 4). Esse manejo, entretanto, trouxe sérias conseqüências, ocasionando declínio na produtividade de frutos, e com agravantes fitossanitários. Houve uma conseqüente queda na qualidade dos frutos destinados ao varejo de fruta fresca, implicando em preços ainda menores para o produtor. Teme-se também o estado do pomar para as próximas safras.

Tabela 4 - Resumo dos custos de produção por hectare, em $\mathbf{R} \$$, na propriedade $C$, referentes às safras 97/98; 98/99 e 99/00, valores corrigidos para janeiro/2001.

\begin{tabular}{|l|c|c|c|c|c|c|}
\hline Itens & $\mathbf{1 9 9 7 / 9 8}$ & $\mathbf{\%}^{*}$ & $\mathbf{1 9 9 8 / 9 9}$ & $\mathbf{\%}$ & $\mathbf{1 9 9 9 / 0 0}$ & $\mathbf{\%}$ \\
\hline Operações mecanizadas & 377,57 & - & 322,91 & - & 310,86 & - \\
\hline Operações manuais & 595,95 & - & 446,51 & - & 489,74 & - \\
\hline Total operações & 973,52 & 81,10 & 769,42 & 76,30 & 800,60 & 85,90 \\
\hline Insumos & 148,53 & 12,40 & 165,42 & 16,50 & 82,71 & 8,90 \\
\hline Administ./Comercialização & 78,34 & 6,50 & 68,37 & 6,80 & 48,52 & 5,20 \\
\hline Custo total/ha/ano & $1.200,39$ & - & $1.003,21$ & - & 931,83 & - \\
\hline Receita bruta/ha/ano & $2.611,37$ & - & $1.953,38$ & - & $1.213,00$ & - \\
\hline Receita líquida/ha/ano & $1.410,98$ & - & 950,17 & - & 281,17 & - \\
\hline
\end{tabular}

* Em relação ao custo total.

\subsection{Dados referentes à propriedade $\mathrm{D}$}

A Fazenda do Haras é parte do desmembramento da antiga Fazenda Ibicoara pertencente a família do sogro do atual proprietário, desde 1943. Inicialmente plantou-se algodão por dois anos. Em seguida passou-se a cultivar café e , principalmente a produção leiteira, com gado girolando, gado gir e gado Holandês. 
Em 05 de maio de 1988, por divisão amigável a parcela de 455,9 hectares, denominada Fazenda do Haras, passa a dedicar-se também a citricultura e a avicultura, atividades que permanecem até hoje, juntamente com a área arrendada para o plantio de cana-de-açúcar.

\subsubsection{Descricão da propriedade D}

- Proprietário: George Fernando Hoffmann

- Principais Atividades Econômicas: citricultura, avicultura e arrendamento para canadeaçúcar;

- Propriedade: área total: 455,9 hectares, sendo 12,10 hectares de área de preservação permanente averbada; 83,88 hectares de estradas internas e áreas de preservação não averbadas; 1,50 hectares de benfeitorias; 115,00 hectares com citros e 243,42 hectares de terras arrendadas para cana-de-açúcar.

- Situação Legal de posse: proprietário

Infraestrutura produtiva:

- 02 aviários com $2.048 \mathrm{~m} 2$ cada um.

- Estábulo para 50 vacas, desativado (utilizado como depósito de fertilizantes)

- 01 galpão para tratores e implementos com estrutura metálica

- 01 reservatório elevado de combustíveis com capacidade para 3000 litros

- 02 tratores Massey Ferguson (275 e 290)

Implementos:

- uma roçadeira hidráulica

- um atomizador de 2000 litros

- uma carreta de 4 rodas

- um "Bim" para 30 toneladas

- um distribuidor de calcário para 5 toneladas

- arado de 3 discos

- uma plaina traseira

- uma grade laranjeira 
Água:

- divisas da propriedade margeadas pelo Ribeirão Bonito, Córrego Tramontina e Santa Rosa

Solos: LATOSSOLO VERMELHO-AMARELO eutrófico

- Drenagem: boa, não apresenta escorrimento superficial

- Relevo plano levemente ondulado predominante, com áreas de meia encosta até a margem dos cursos de água.

Insumos:

- Acaricidas de última geração

- Adubo foliar + uréia

- Superfosfato simples

- NPK 20-00-20

- Calcário dolomítico

- Enxofre

- Fungicida cúprico

- Nitrato de potássio

- Herbicida a base de glifosato

- Isca para mosca da fruta

\section{Comercialização:}

Produção voltada para a indústria, tendo se associado a Sucorrico em 1998. Na safra $99 / 00$, devido aos baixos preços da laranja, optou por vender a fruta no pé, economizando os custos de colheita e transporte.

\section{Benfeitorias:}

- 03 casas para funcionários com 6 cômodos e garagem

Mão de obra:

05 funcionários, sendo $3 \mathrm{em}$ período integral e 2 em tempo parcial.

\section{Produção:}

- Laranjas pêra, valência e hamlin 


\subsubsection{Custos de producão da propriedade D}

A propriedade D é aquela cujo manejo mais se aproxima do convencional para a citricultura, como proposto na planilha de custos da referência utilizada (AGRIANUAL/99), excetuando-se o número de operações e a quantidade de insumos, tendo em vista os preços em queda do setor citrícola, no referido período. Operações manuais invariavelmente custam mais do que as mecanizadas (podem chegar a até o dobro, dependendo das necessidades específicas do ano), sendo que a colheita representa sempre mais do que a metade desse custo. Por essa razão, na safra 99/00, o proprietário $\mathrm{D}$ optou por vender a fruta no pé, para evitar despesas com a colheita e a comercialização (tabela 5).

Tabela 5 - Resumo dos custos de produção por hectare, em R\$, na propriedade D, referentes às safras 97/98; 98/99 e 99/00, valores corrigidos para janeiro/2001.

\begin{tabular}{|l|c|c|c|c|c|c|}
\hline Itens & $\mathbf{1 9 9 7 / 9 8}$ & $\mathbf{\% *}$ & $\mathbf{1 9 9 8 / 9 9}$ & $\mathbf{\%}$ & $\mathbf{1 9 9 9 / 0 0}$ & $\mathbf{\%}$ \\
\hline Operações mecanizadas & 567,89 & - & 486,43 & - & 489,38 & - \\
\hline Operações manuais & 612,34 & - & 512,34 & - & 195,60 & - \\
\hline Total operações & 1180,23 & 59,00 & 998,77 & 57,00 & 684,98 & 61,09 \\
\hline Insumos & 473,38 & 23,70 & 425,68 & 24,30 & 393,09 & 35,06 \\
\hline Administ./Comercialização & 345,76 & 17,30 & 326,91 & 18,70 & 43,12 & 3,85 \\
\hline Custo total/ha/ano & 1999,37 & - & 1751,36 & - & $1.121,19$ & - \\
\hline Receita bruta/ha/ano & 2366,07 & - & 2401,92 & - & $1.633,50$ & - \\
\hline Receita líquida/ha/ano & 336,70 & - & 650,56 & - & 512,31 & - \\
\hline
\end{tabular}

* Em relação ao custo total.

\subsection{Dados referentes à propriedade $\mathrm{E}$}

A empresa teve seu início com a vinda de Don Manuel Archelós Blasco ao Brasil. Oriundo da região de Valência na Espanha, Don Manuel Blasco foi convidado pela empresa Citrobrasil S/A para gerenciar as atividades da empresa no interior do estado de São Paulo. No ano de 1948, Don Manuel Blasco adquiriu a Fazenda Jaraguá no município de Araras - SP para produzir citros. Em 1967, Edmundo 
Eugênio Archelós Blasco, filho único de Don Manuel Blasco, assumiu as atividades da empresa.

Quatro anos mais tarde, em 1971, houve a incorporação de uma outra propriedade na região de Pirassununga - SP, surgindo assim a Fazenda Indaiá. Em 1975, Edmundo Blasco uniu-se à família Brenner para adquirir a Fazenda Princesa no município de Dobrada - SP.

A compra da Fazenda Raio de Sol no município de Itirapina - SP, objeto de acompanhamento deste estudo, foi efetuada em 1984. Em 1985, o grupo decide pela venda da Fazenda Princesa e adquire Fazenda Vista Verde, vizinha à Fazenda Raio de Sol. Em 1998, o grupo tornou-se um dos maiores acionista da indústria de suco de laranja Sucorrico S/A - Araras - SP.

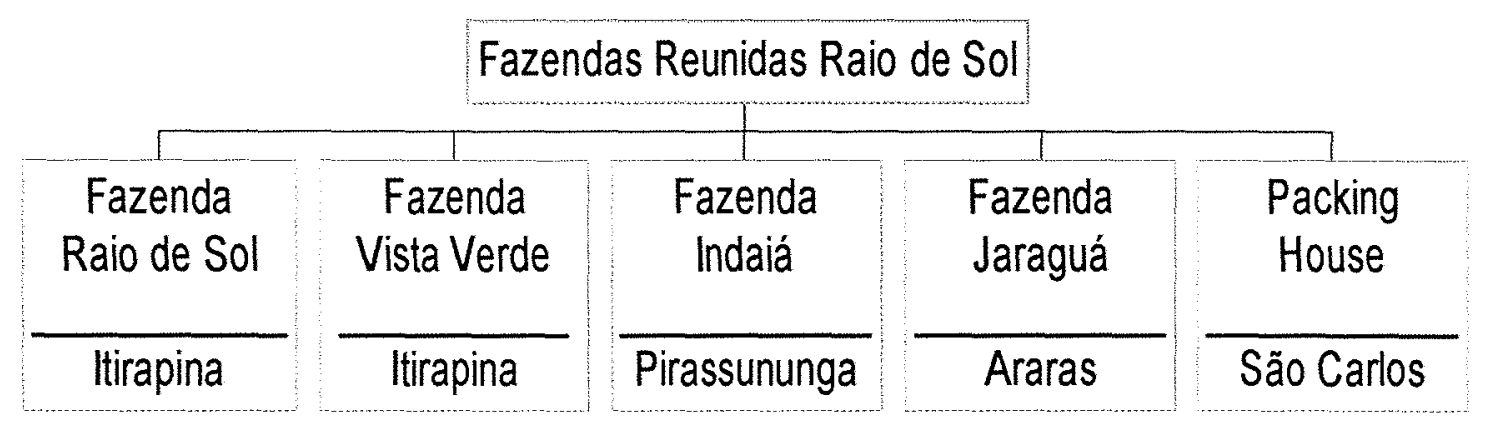

Figura 3: Configuração atual da empresa Fazendas Reunidas Raio de Sol.

Atualmente, as propriedades que compõem as Fazendas Reunidas Raio de Sol totalizam uma área de 2.829 hectares, com aproximadamente 1 milhão de pés de citros. Destes, apenas $60 \%$ dos pés estão em fase de produção e os demais $40 \%$ ainda estão em formação. O cultivo de onze diferentes variedades de citros tem permitido colheitas em diferentes épocas do ano. A produção atual do grupo é de aproximadamente 50.000 toneladas de citros anuais.

Há cerca de 12 anos a empresa vem fomentando pesquisas que desenvolvam técnicas de produção que não agridam o meio ambiente. Com perspectiva de chegar a 82.000 toneladas de citros dentro de quatro anos, o plano original de destinar metade da produção à indústria de suco de laranja concentrado e outra metade para o mercado de fruta fresca, não tem atingido os resultados esperados, nos últimos anos, em função dos baixos preços da laranja. Em razão disso, sentiu-se a necessidade 
de possuir uma unidade de beneficiamento própria, pois as grandes redes varejistas têm procurado diretamente os produtores, evitando os atacadistas.

Desta forma, no início do ano 2000, decidiu-se montar uma unidade de beneficiamento numa região que ficasse próxima às áreas de produção. Foi importado um equipamento de última geração para classificação de frutas através do sistema óptico. Isto permitirá uma padronização quase perfeita da fruta a ser embalada, atendendo a necessidade e expectativa de cada cliente.

Como na Fazenda Raio de Sol já há uma grande área de produção de frutas sem o uso de agrotóxicos, vários grupos na Europa, Canadá e Ásia têm demonstrado interesse firme em adquirir esse produto. Inicialmente, a previsão é de exportar cerca de 4.000 toneladas de fruta fresca por ano. Uma empresa suíça de auditoria (uma das maiores do mundo) foi contratada para vistoriar e certificar toda a fruta produzida pela empresa, que será beneficiada no "packing house" situado em São Carlos, a partir de fevereiro/2001.

\subsubsection{Descrição da propriedade $\mathrm{E}$}

- Proprietário: Edmundo Eugênio Archelós Blasco e Outros

- Endereço: Rodovia Washington Luiz, km 226,74 - Caixa Postal : 115

CEP 13.560-970 - São Carlos - SP

- Principal atividade econômica: citricultura

- Propriedade: área total: 1.430 hectares

- Situação legal de posse: proprietário

Infraestrutura produtiva:

Poço artesiano com vazão de 45.000 litros/hora

Máquinas: 23 tratores Valmet 885

Implementos: 
12 pulverizadores com atomizador de 2.000 litros

02 roçadeiras duplas

04 roçadeiras simples

03 carretas de 04 rodas

02 roçadeiras laterais

02 roçadeiras de topo

01 semeadora de plantio direto para milho de 04 linhas

01 semeadora de plantio direto para soja de 07 linhas

01 semeadora de capim TD 300 Semeato

Água: em uma das divisas a propriedade é margeada pelo Ribeirão Água Branca

Solos: NEOSSOLO QUARTZARÊNICO Órtico, com manchas de ARGISSOLO VERMELHO-AMARELO Distófico típico .

- Drenagem: boa, não apresenta escorrimento superficial

- Cobertura vegetal original: campo sujo de cerrado, Eucaliptus spp

- Presença de cupins e formigas: Formigas saúva e quenquém, controle com Boveria spp e Metarrizhium

Produção:

- Laranja Bahia e Bahianinha : 42.104 pés em 101,14 hectares

- Laranja Hamlin: 6.503 pés em 12,57 hectares

- Laranja Homossassa: 5.344 pés em 9,45 hectares

- Laranja João Nunes: 8.439 pés em 13,30 hectares

- Laranja Lima Verde: 55.806 pés em 158,59 hectares

- Laranja Lima: 31.140 pés em 69,61 hectares

- Laranja Natal: 62.892 pés em 218,89 hectares

- Laranja Pera: 134.785 pés em 385,94 hectares

- Laranja Valência Folha Murcha: 8.834 pés em 19,92 hectares

- Laranja Valência: 33.667 pés em 127, 57 hectares

- Tangerina Cravo: 3.969 pés em 7,31 hectares

- Tangerina Murcote: 57.637 pés em 148, 12 hectares

- Tangerina Ponkan: 20.994 pés em 50,20 hectares

Insumos:

- Calda bordalesa: 140.000 litros/ano

- Calda sufocálicica: 500.000 litros/ano

- Biofertilizante: 130.000 litros/mês 
- Termofosfato: 260 toneladas/ano

\section{Comercialização:}

Planejamento da produção: destinar $50 \%$ das frutas para a indústria e $50 \%$ para o consumo in natura.

Safra $99 / 00$ - destinou 400.000 caixas para o mercado interno (fruta fresca) e 600.000 caixas para a indústria (FCOJ)

Em 2001 está programado o processamento de 80 a 100.000 caixas para exportação de suco de laranja orgânico.

Mão-de-obra:

- Número de pessoas: 74 pessoas, sendo 07 famílias residentes na propriedade.

- Disponibilidade de mão-de-obra na região: contrata turma de Leme, chegando a ter mais de 300 pessoas/dia trabalhando na colheita e na carpa.

Administração:

- Administrador, encarregados e 01 Engenheiro Agrônomo

\subsubsection{Custos de producão da propriedade $\mathrm{E}$}

Os custos de produção na propriedade $\mathrm{E}$ têm sido mais elevados que a média das demais (tabela 6). Isso pode ser creditado a dois fatores: a transição do manejo para uma forma mais sustentável e, no último ano, em razão do fechamento de contrato de exportação de suco de laranja orgânica para a França, foi necessário substituir a adubação mineral potássica e nitrogenada por insumos autorizados pela certificadora européia. 
Tabela 6 - Resumo dos custos de produção por hectare, em $R \$$, na propriedade $E$, referentes às safras 97/98; 98/99 e 99/00, valores corrigidos para janeiro/2001.

\begin{tabular}{|l|c|c|c|c|c|c|}
\hline Itens & $\mathbf{1 9 9 7 / 9 8}$ & $\mathbf{\% *}^{*}$ & $\mathbf{1 9 9 8 / 9 9}$ & $\mathbf{\%}$ & $\mathbf{1 9 9 9 / 0 0}$ & $\mathbf{\%}$ \\
\hline Operações mecanizadas & 882,41 & - & 821,33 & - & 962,96 & - \\
\hline Operações manuais & 534,50 & - & 505,17 & - & 958,00 & - \\
\hline Total operações & $1.416,91$ & 58,67 & $1.326,50$ & 61,50 & $1.920,96$ & 54,48 \\
\hline Insumos & 656,11 & 27,17 & 516,55 & 23,95 & $1.092,58$ & 30,99 \\
\hline Administ./Comercialização & 342,05 & 14,16 & 313,30 & 14,55 & 512,32 & 14,53 \\
\hline Custo total/ha/ano & $2.415,07$ & - & $2.156,35$ & - & $3.525,86$ & - \\
\hline Receita bruta/ha/ano & $4.036,21$ & - & $3.086,85$ & - & $5.248,26$ & - \\
\hline Receita líquida/ha/ano & $1.621,14$ & - & 930,50 & - & $1.722,40$ & - \\
\hline
\end{tabular}

*Em relação ao custo total.

4.6 Dados referentes as análises de solo

A seguir, na tabela 7, estão apresentados os resultados das análises de solo realizadas nas cinco propriedades:

As análises químicas de planta e demais análises de solo realizadas estão presentes no Anexo B. 
Tabela 7 - Análises de solo realizadas nos anos de 1998, 1999 e 2000 em talhões de laranja pêra de cinco propriedades da região de São Carlos, SP.

\begin{tabular}{|c|c|c|c|c|c|c|c|c|c|c|c|c|}
\hline \multirow[b]{2}{*}{ Propr. } & \multirow{2}{*}{$\begin{array}{c}\text { Ano } \\
\text { Profdd. de } \\
\text { amostrage } \\
\mathrm{m}(\mathrm{cm})\end{array}$} & P Resina & M.O. & $\mathrm{pH}$ & $\mathrm{K}$ & $\mathrm{Ca}$ & $\mathrm{Mg}$ & $\mathrm{H}+\mathrm{Al}$ & $\mathrm{Al}$ & $\mathrm{SB}$ & CTC & \multirow[t]{2}{*}{$V \%$} \\
\hline & & $\mathrm{mg} / \mathrm{dm}^{3}$ & $\mathrm{~g} / \mathrm{dm}^{3}$ & $\mathrm{CaCl}_{2}$ & \multicolumn{7}{|c|}{$\mathrm{mmol} d \mathrm{dm}^{3}$} & \\
\hline A & $98(0-20)$ & 48 & 31 & 5,9 & 2,6 & 26 & 8 & 19 & 0 & 36,6 & 55,6 & 66 \\
\hline A & $99(0-20)$ & 55 & 32 & 6,1 & 2,4 & 44 & 11 & 19 & 0 & 57,4 & 76,4 & 75 \\
\hline $\mathrm{A}$ & $00(0-20)$ & 76 & 33 & 6,0 & 2,5 & 52 & 10 & 21 & 0 & 64,5 & 85,5 & 75 \\
\hline B & $98(0-20)$ & 43 & 17 & 5,3 & 2,8 & 18 & 5 & 17 & 0,6 & 25,8 & 42.8 & 60 \\
\hline B & $99(0-20)$ & 35 & 17 & 5,7 & 2,4 & 15 & 7 & 16 & 0 & 24,4 & 40,4 & 60 \\
\hline B & $00(0-20)$ & 34 & 16 & 5,6 & 2,3 & 16 & 6 & 15 & 0 & 24,3 & 39,3 & 62 \\
\hline $\mathrm{C}$ & $98(0-20)$ & 7 & 25 & 4,9 & 1,1 & 25 & 9 & 31 & 2,4 & 35.1 & 66,1 & 53 \\
\hline C & $99(0-20)$ & 11 & 12 & 5,2 & 0,6 & 15 & 6 & 21 & 0 & 21,6 & 42,6 & 51 \\
\hline $\mathrm{C}$ & $00(0-20)$ & 8 & 15 & 5,0 & 0,6 & 16 & 7 & 20 & 0,2 & 23.6 & 43,6 & 54 \\
\hline D & $98(0-20)$ & 8 & 17 & 5,3 & 1,9 & 12 & 3 & 15 & 0 & 16.9 & 31,9 & 53 \\
\hline D & $99(0-20)$ & 7 & 17 & 5,1 & 1,6 & 19 & 6 & 24 & 1,2 & 26.6 & 50,6 & 53 \\
\hline $\mathrm{D}$ & $99(20-40)$ & 5 & 13 & 4,9 & 1,2 & 15 & 6 & 24 & 1,4 & 22.2 & 46.2 & 48 \\
\hline $\mathrm{D}$ & $00(0-20)$ & 6 & 11 & 4,8 & 1,0 & 9 & 3 & 22 & 2,8 & 13,0 & 35,0 & 37 \\
\hline D & $00(20-40)$ & 3 & 10 & 4,4 & 0,8 & 8 & 3 & 22 & 3,6 & 11.8 & 33,8 & 35 \\
\hline$E$ & $98(0-20)$ & 44 & 14 & 5,5 & 1,0 & 17 & 6 & 22 & 0 & 24,0 & 46,0 & 52 \\
\hline$E$ & $98(20-60)$ & 5 & 7 & 4.8 & 0,6 & 8 & 3 & 24 & 1,9 & 11,6 & 35,6 & 33 \\
\hline $\mathrm{E}$ & $99(0-20)$ & 48 & 15 & 5,6 & 1,10 & 19 & 7 & 21 & 0 & 27,1 & 48,1 & 56 \\
\hline$E$ & $99(20-60)$ & 6 & 8 & 4,9 & 0,70 & 9 & 3 & 22 & 1,8 & 12,7 & 34,7 & 37 \\
\hline $\mathrm{E}$ & $00(0-20)$ & 49 & 15 & 5,7 & 1,3 & 22 & 8 & 20 & 0 & 31,3 & 51,3 & 61 \\
\hline$E$ & $00(20-60)$ & 8 & 9 & 5,1 & 0,9 & 11 & 4 & 21 & 1,2 & 15,9 & 36,9 & 43 \\
\hline
\end{tabular}


Na propriedade $\mathrm{E}$ a citricultura foi implantada a partir de 1986. A maior parte da unidade produtiva é composta por NEOSSOLO QUARTZARÊNICO Órtico, com baixíssima fertilidade natural, deficiente em cargas negativas para reter os nutrientes. Nos dois primeiros anos problemas como a alta temperatura do solo, erosão por água e vento e dificuldades fitossanitárias indicavam a inviabilidade da exploração agrícola da fazenda. Por essa razão, optou por buscar formas alternativas de manejo, encontrando no princípio da cobertura de palha do plantio direto (PD) o caminho para se buscar a sustentabilidade do sistema. Passou a adotar o PD com cereais antes da implantação dos pomares e o plantio da Brachiaria ruziziensis nas entrelinhas dos citros. A partir de 1992, substituiu a adubação fosfatada com supertriplo por termofosfato. A partir de 1994 passou a utilizar parâmetros próprios para a reposição de nitrogênio e potássio, reduzindo a quantidade de adubos de alta solubilidade. Paulatinamente foi substituindo os acaricidas e fungicidas por calda sulfocálcica e bordalesa.

Melarato (1999) considera que existe uma grande quantidade de espécies vegetais que podem coexistir normalmente com culturas perenes, sendo que a presença das mesmas é uma excelente oportunidade de aumentar a biodiversidade, tanto da fauna quanto da flora, aumentando a resistência do agroecossistema em questão. A cobertura do solo proporciona também redução no escorrimento superficial, além da infiltração mais rápida da água da chuva. Além disso, a perda de nutrientes também será reduzida, pois o sistema radicular das espécies localizadas nas entrelinhas dos pomares, estará explorando uma área maior do solo.

A adubação mineral na propriedade E é feita sobre a Brachiaria, que é roçada cerca de três vezes na primavera-verão e mantida sem roçar no outono-inverno. Atualmente, a vegetação esparsa que surge sob a copa é roçada, quando antes se eliminava com glifosato. Toda essa matéria orgânica induz a reciclagem de nutrientes, aspecto fundamental no manejo sustentável de um agroecossistema. Segundo Miyazawa et al. (2000), num solo frágil, ácido e dependente de matéria orgânica como aquele da fazenda $\mathrm{E}$, o correto manejo de resíduos vegetais é essencial. A recomendação é 
justamente deixar os retos vegetais sobre o solo, e não incorporá-lo, para que lentamente os ácidos orgânicos percolem através do perfil, neutralizando a acidez até a camada subsuperficial, bem como transportando o Ca.

De acordo com os parâmetros propostos por Lopes (1984), a "construção da fertilidade de um solo", como o da propriedade $\mathrm{E}$, requereria uma adubação corretiva com grandes quantidades de calcário, fertilizantes fosfatados de alta solubilidade e também altas dosagens de fertilizantes potássicos. Além disso, dever-se-ia fazer uma adubação de manutenção com NPK + Enxofre e micronutrientes em quantidades também elevadas, especialmente em solos arenosos.

Segundo estudos de Raij (1983) para o Estado de São Paulo, a recomendação para culturas perenes como citros seria de elevar a saturação de bases a um patamar mínimo de $60 \%$. A propriedade $\mathrm{E}$ iniciou a implantação de seu pomar em 1986, seguindo rigorosamente esses parâmetros, sendo que as análises então realizadas comprovavam a rápida elevação dos níveis de macro e micronutrientes, bem como o aumento da saturação de bases. A resposta das plantas, entretanto, não correspondeu à expectativa inicial.

\subsection{Dados referentes à produtividade:}

Conforme os resultados de produção apresentados na Tabela 8, com tal manejo tem obtido produtividade crescente ao longo dos anos, com níveis estáveis da saturação de bases em torno de 45 a $50 \%$, conforme tabela 7 , sem realizar calagem nos últimos cinco anos. Os níveis dos macronutrientes têm permanecido estáveis, com redução gradual da aplicação de adubos de maior solubilidade que têm sido substituídos por pulverizações mensais de biofertilizante, preparados através da fermentação durante 40 dias, de esterco fresco de curral, leite, melaço, micronutrientes e fungos, na proporção de 1:33,33 (ou concentração de $0,03 \%$ ). 
Tabela 8 - Produção de citros por pé (caixas de 40,8 kg), variedade "pêra", em talhões de cinco propriedades da região de São Carlos, SP.

\begin{tabular}{|c|c|c|c|c|c|}
\hline PROPRIEDADE & Área (ha) & $\mathbf{N}^{\mathbf{0}}$ pés & $\mathbf{1 9 9 7 / 9 8}$ & $\mathbf{1 9 9 8 / 9 9}$ & $\mathbf{1 9 9 9 / 2 0 0 0}$ \\
\hline $\mathrm{A}$ & 1,00 & 304 & 1,30 & 1,41 & 1,91 \\
\hline $\mathrm{B}$ & 1,00 & 300 & 1,61 & 1,54 & 1,85 \\
\hline $\mathrm{C}$ & 2,40 & 727 & 1,52 & 1,42 & 1,33 \\
\hline $\mathrm{D}$ & 10,00 & 3000 & 1,33 & 1,44 & 1,65 \\
\hline $\mathrm{E}$ & 10,01 & 3096 & 1,70 & 1,87 & 3,32 \\
\hline MÉDIA & 4,88 & 1485,4 & 1,49 & 1,54 & 2,01 \\
\hline
\end{tabular}

\subsection{Dados referentes à comercialização:}

Sem deixar de considerar a importância da eficiência técnica e agronômica, é preciso analisar também a rentabilidade obtida pelos sistemas produtivos, pilar indispensável para a sustentabilidade agrícola. Na tabela 9 estão apresentados os preços obtidos pelos cinco produtores nas últimas três safras. Apesar das diferenças de manejo entre as propriedades e da qualidade dos frutos obtidos, os preços de mercado não sofrem diferenciação, pois são diretamente influenciados pelas cotações internacionais. A exceção seria no caso de produtos orgânicos, que têm alcançado valores bem superiores quando exportados para os países do $1^{\circ}$ Mundo.

É importante destacar que com recuperação da produção norte-americana, no final da década de 90, a União Européia tem sido o principal destino das exportações de suco concentrado de laranja brasileiro, conforme indica a tabela 10 , sem que haja, entretanto, uma perspectiva de ampliação de mercados, pelo menos a curto prazo. 
Tabela 9 - Preços obtidos* por caixa de $40,8 \mathrm{~kg}$ da laranja pêra pelos proprietários de cinco pomares da região de São Carlos, SP.

\begin{tabular}{|c|c|c|c|}
\hline PROPRIEDADE & $1997 / 98$ & $1998 / 99$ & $1999 / 2000$ \\
\hline A & 6,23 & 5,55 & 4,21 \\
\hline B & 6,55 & 5,32 & 3,12 \\
\hline C & 5,67 & 4,54 & 3,01 \\
\hline D & 5,93 & 5,56 & 3,30 \\
\hline E & 7,81 & 5,43 & 5,20 \\
\hline MÉDIA & 6,44 & 5,28 & 3,97 \\
\hline
\end{tabular}

* valores corrigidos em R $\$$ - janeiro/2001

Tabela 10 - Exportações brasileiras de suco concentrado de laranja (FCOJ), no ano de 2000 , expressa em toneladas.

\begin{tabular}{|c|c|c|c|c|c|c|}
\hline MÉS & $\begin{array}{c}\text { UNIAOO } \\
\text { EUROPÉIA }\end{array}$ & NAFTA & ASIA & MERCOSUL & OUTROS & TOTAL \\
\hline Janeiro & 45.514 & 36.309 & 4.702 & 600 & 4.260 & 97.385 \\
\hline Fevereiro & 59.915 & 18.830 & 11.939 & 593 & 2.097 & 93.374 \\
\hline Marco & 42.283 & 15.684 & 19.639 & 379 & 4.427 & 82.412 \\
\hline Abril & 62.978 & 16.355 & 7.373 & 374 & 3.372 & 90.452 \\
\hline Maio & 49.813 & 28.417 & 3.714 & 375 & 1.323 & 83.642 \\
\hline Junho & 47.649 & 18.087 & 20.915 & 515 & 3.629 & 90.795 \\
\hline Julho & 73.121 & 9.287 & 4.711 & 269 & 2.134 & 89.522 \\
\hline Agosto & 64.927 & 27.028 & 9.211 & 148 & 1.711 & 103.025 \\
\hline Setembro & 66.900 & 28.894 & 9.725 & 316 & 3.165 & 109.000 \\
\hline Outubro & 80.533 & 20.821 & 7.745 & 190 & 3.785 & 113.074 \\
\hline Novembro & 108.860 & 50.870 & 2.437 & 39 & 3.238 & 165.444 \\
\hline Dezembro & 82.742 & 16.872 & 26.093 & 116 & 2.768 & 128.591 \\
\hline TOTAL & 785.235 & 287.454 & 128.204 & 3.914 & 35.909 & 1.240 .716 \\
\hline ACUMULADO & & & & & & \\
\hline
\end{tabular}

Fonte: Abecitrus/Secex 
Outro fato importante é que com o aumento da produção em virtude dos preços obtidos no início da década de noventa, o mercado interno que estava habituado a receber cerca 60 milhões de caixas, foi abarrotado por mais de cem milhões de caixas nos últimos anos, conforme indica a Figura 4.

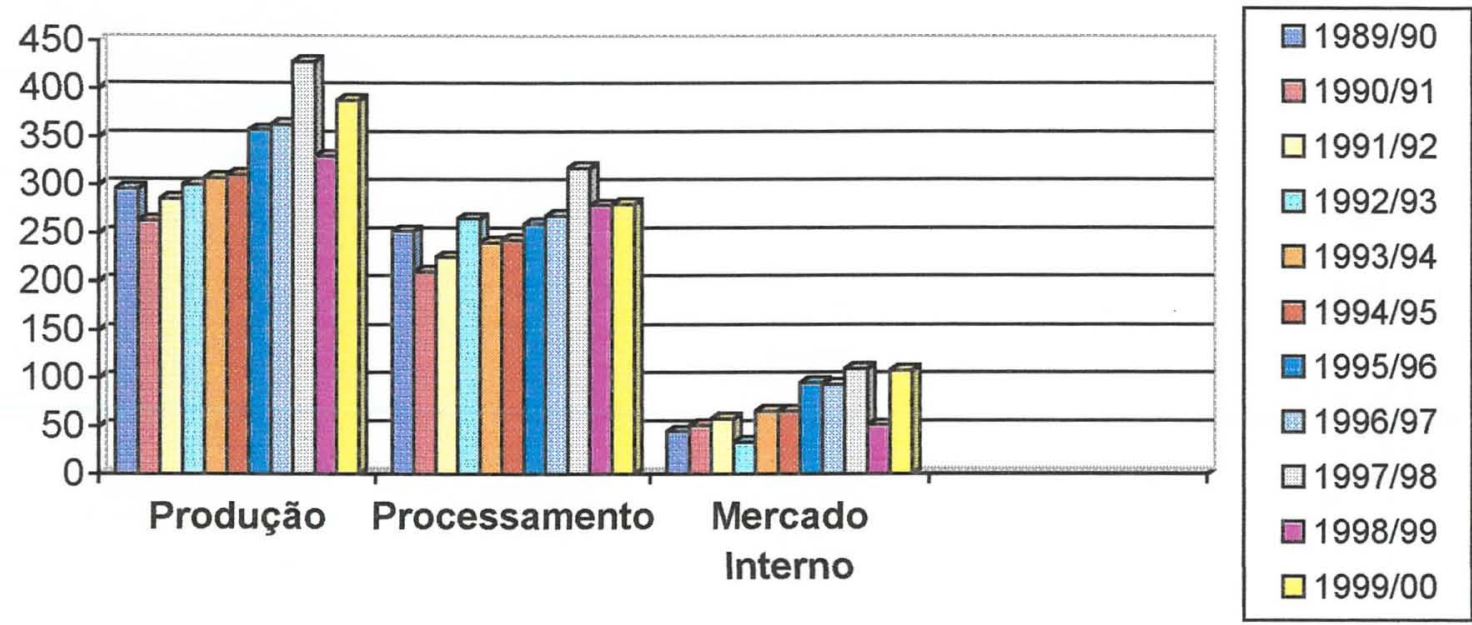

Figura 4 - Produção, processamento e consumo de laranja (em milhões de caixas de $40,8 \mathrm{~kg})$

Na Figura 5 está representada a participação das regiões de Araraquara e Limeira na produção citrícola paulista.

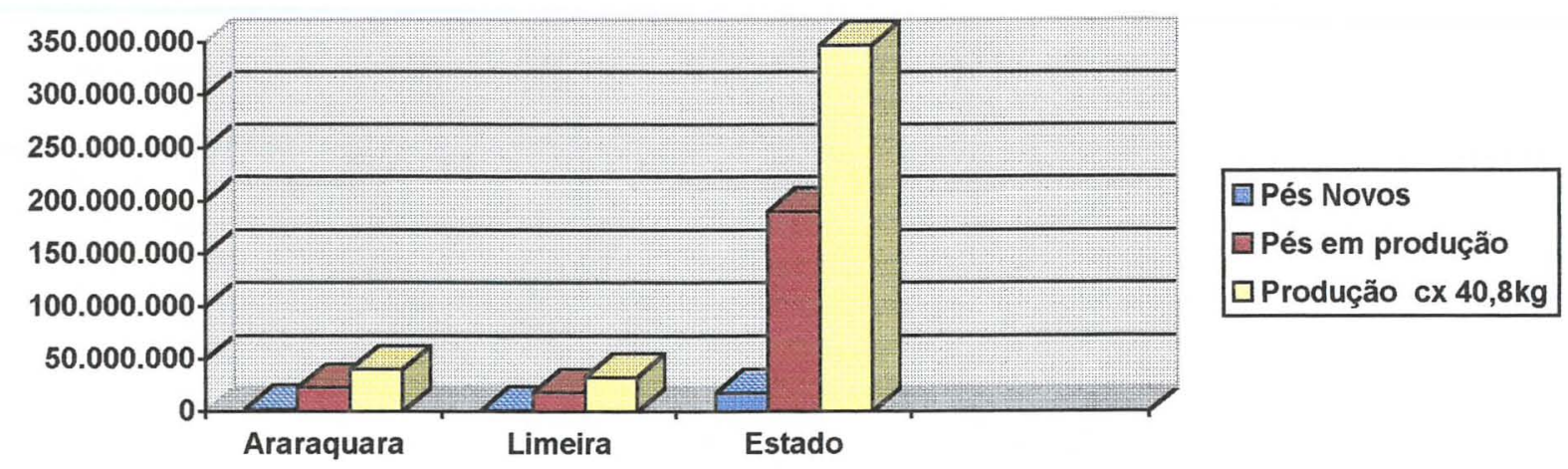

Figura 5:- Produção citrícola, em milhões de caixas, nas regiões de Araraquara e Limeira, em comparação ao Estado de São Paulo. 


\subsubsection{Dados referentes à comercialização de produtos orgânicos}

São claras as indicações de que o mercado de produtos orgânicos cresce de modo irreversível. Nesse contexto, a Associação de Agricultura Orgânica (AAO), uma das principais entidades certificadoras do Estado de São Paulo, juntamente com o Instituo Biodinâmico, têm procurado tornar os agricultores certificados cada vez mais conscientes e organizados. As questões ambientais, como a contaminação do solo, água, ar e, principalmente, dos alimentos, a cada dia que passa tornam-se uma preocupação de grande parte da população, o que favorece ainda mais a expansão da agricultura orgânica. A mídia, refletindo essas preocupações, tem trazido o tema à discussão por intermédio de reportagens que denunciam graves contaminações de trabalhadores rurais e de alimentos, o que têm causado grande impacto.

Tem, por outro lado, crescido significativamente o número de produtores rurais interessados em produzir visando a sustentabilidade agrícola. Os dados apresentados na Tabela 11 refletem essa realidade.

Tabela 11 - Número total de agricultores certificados pela Associação de Agricultura Orgânica (AAO) até maio de 2000.

\begin{tabular}{|l|c|c|c|}
\hline \multicolumn{1}{|c|}{ Período } & Aprovados & Em transição & $\%$ acumulada \\
\hline Até dez de 1996 & 26 & - & 7 \\
\hline Até dez. de 1997 & 49 & - & 20 \\
\hline Até dez. de 1998 & 100 & - & 46 \\
\hline Até jan. de 2000 & 116 & 24 & 77 \\
\hline Maio de 2000 & 89 & 120 & 100 \\
\hline Total & 380 & - & 100 \\
\hline
\end{tabular}

Fonte: AAO.

Levando em conta os limitados recursos disponíveis para a pesquisa e a produção baseadas em premissas voltadas para a sustentabilidade dos agroecossistemas, os resultados obtidos por setores que podemos considerar como precursores da Agroecologia, têm, em muitas das vezes, superado as expectativas, tanto do setor produtivo, quanto de pesquisadores. 
Cabe destacar que sistemas de produção como o que está sendo desenvolvido na propriedade $\mathrm{E}$, acompanhada neste estudo, sinalizam de forma promissora com relação ao grande potencial produtivo dos mesmos, contrariando a maioria das considerações levantadas sobre a temática da produção sem agrotóxicos, cuja viabilidade sempre foi considerada restrita à pequena propriedade e a escala quase artesanal.

Fica patente a necessidade de incluir na definição das políticas públicas, mecanismos e disponibilização de recursos, de forma prioritária, para o desenvolvimento da pesquisa agropecuária e da produção voltada para a sustentabilidade agrícola, pelos diversos benefícios que a evolução desse setor, ainda incipiente em nosso país, pode trazer para a coletividade. 


\section{5-CONCLUSÕES}

1. Mesmo em grande escala é viável produzir citros sem o uso de produtos sintéticos usualmente recomendados para o controle de pragas e doenças dessa cultura, desde que se faça um manejo cuidadoso do pomar em termos de reciclagem de nutrientes através de plantas, suplementando-se com biofertilizantes e caldas minerais.

2. A produção de citros por pequenos produtores somente pode ser rentável se os custos de produção forem reduzidos, sem contudo comprometer a sanidade e a fertilidade dos pomares.

3. A comercialização de citros é o grande fator a estabelecer a rentabilidade dessa cultura. Sendo que no caso da citricultura paulista a maior influência é exercida pela cotação do suco de laranja concentrado e congelado no mercado internacional.

4. Atualmente existe uma demanda reprimida, nos países do $1^{\circ}$ Mundo, para o suco de laranja produzido organicamente, proporcionando preços bem acima do mercado convencional, ao menos nos próximos anos. 


\section{AXEXO A: Cálculos dos Custos de Produção}

Tabela A1-Custos de produção por hectare, na região de Araraquara, em $\mathrm{R} \$$, referentes ao ano de 2000, valores corrigidos em R\$ - janeiro/2001 (AGRIANUAl, 99)

\begin{tabular}{|c|c|c|c|c|}
\hline \multirow[t]{2}{*}{ DESCRIÇÃO } & \multirow[t]{2}{*}{ ESPECIFICAÇÃO } & \multirow[t]{2}{*}{ V.U. } & \multicolumn{2}{|c|}{$\begin{array}{l}\text { MANUTENÇĀO } \\
\text { PROD } \\
\text { ESTÁVEL ANO } \\
\text { 8 AO } 16\end{array}$} \\
\hline & & & Qtde. & TOTAL \\
\hline \multicolumn{5}{|c|}{ A. OPERACÔES MECANIZADAS } \\
\hline \multicolumn{5}{|c|}{\begin{tabular}{|l|l|} 
A1. Preparo do Solo & \\
\end{tabular}} \\
\hline Calagem & HM Tp 61 cv. $4 \times 2+$ distr. Calcário $2,3 \mathrm{~m}^{3}$ & 28,52 & 0.50 & 14,26 \\
\hline \multicolumn{5}{|l|}{ A2. Tratos Culturais } \\
\hline Pulverização (4x) & HM Tp $61 \mathrm{cv} .4 \times 2+$ atomizador 20001 & 34,80 & 7,20 & 250,56 \\
\hline Roçagem $(4 x)$ & HM Tp $61 \mathrm{cv} .4 \times 2$ + roçad. Hidraúlica & 26,02 & 6.00 & 156,12 \\
\hline Combate à Mosca $(12 \mathrm{x})$ & HM Tp 61 cv $4 \times 2+$ pulv. 4001 & 26,52 & 4,80 & 127,30 \\
\hline Gradagem nas entrelinhas & HM Tp 61 cv. $4 \times 2+$ gr. Niv. $28 \times 20^{\prime \prime}$ & 25,58 & 1,00 & 25,58 \\
\hline Aplic. de Herbicida (1x. 2x, 2x) & HM Tp 61 cr. $4 \times 2+$ pulv. Barras & 27,06 & 2,40 & 64,94 \\
\hline Adubação (4x) & HM Tp 61 cv $4 \times 2+$ adubadora & 28,52 & 3,20 & 91,26 \\
\hline Manutenção de Carreador & HM Tp $126 \mathrm{cv} .4 \times 4+$ patrol & 24,86 & 0,30 & 7,46 \\
\hline \multicolumn{5}{|l|}{ A3. Colheita } \\
\hline Colheita & HM Tp $61 \mathrm{cv} .4 \times 2+$ carreta & 24,86 & 5,00 & 124,30 \\
\hline Subtotal A & & & & 861,78 \\
\hline \multicolumn{5}{|l|}{$\begin{array}{l}\text { B-OPERACÕES MANUAIS } \\
\text { B1. Preparo do solo }\end{array}$} \\
\hline Calagem & Homem-dia & 18,86 & 0,13 & 2,45 \\
\hline \multicolumn{5}{|l|}{ B2. Tratos Culturais } \\
\hline Adubação $(4 x)$ & Homem-dia & 18,86 & 0,40 & 7,54 \\
\hline Poda de Limpeza & Homem-dia & 18,86 & 10,00 & 188,6 \\
\hline Combate à Formiga $(12 \mathrm{x})$ & Homem-dia & 18,86 & 0.60 & 11,32 \\
\hline Limpeza pomar /Podas & Homem-dia & 18,86 & 1,20 & 22,64 \\
\hline \multicolumn{5}{|l|}{ B3. Colheita } \\
\hline Colheita & Empreita (cx 40,8 kg) & 1,00 & 1.050 & $1.050,00$ \\
\hline \multicolumn{5}{|l|}{ Subtotal B } \\
\hline VALOR A TRANSPORTAR & & & & $1.282,55$ \\
\hline \multicolumn{5}{|l|}{$\begin{array}{l}\text { C-INSUMOS (CIF) } \\
\text { C1. Fertilizantes }(*)\end{array}$} \\
\hline Calcário & $\mathrm{R} \$ /$ ton & 45,24 & 1,00 & 45,24 \\
\hline Superfosfato Simples & $\mathrm{R} \$ /$ ton & 256,04 & 0,39 & 98,85 \\
\hline Cloreto de Potássio & $\mathrm{R} \$$ /ton & 418,20 & 0,24 & 100,37 \\
\hline Nitrocálcio & $\mathrm{R} \$ /$ ton & 363,58 & 1,10 & 399,94 \\
\hline Uréia & $\mathrm{R} \$ /$ ton & 341,38 & 0,02 & 6,83 \\
\hline Esterco de Galinha & $\mathrm{R} \$ /$ ton & 59,74 & & \begin{tabular}{|l|}
0 \\
\end{tabular} \\
\hline Sulfato de Zinco & $\mathrm{R} \$ / \mathrm{Kg}$ & 2,00 & 9,00 & 18,00 \\
\hline Sulfato de Manganês & $\mathrm{R} \$ / \mathrm{Kg}$ & 1,90 & 6,00 & 11,4 \\
\hline Ácido Bórico & $\mathrm{R} \$ \mathrm{Kg}$ & 2,78 & 3,00 & 8,34 \\
\hline C2. Fitossanitário & $\mathrm{R} \$ / \mathrm{Kg}$ & & & 0 \\
\hline Espalhante & $\mathrm{RS/litro}$ & 5,12 & 3,60 & 18,43 \\
\hline Oleo Mineral & R\$/litro & 2,64 & 24,00 & 63,36 \\
\hline Acaricida & R\$/litro & 28,28 & 15,36 & 434,38 \\
\hline
\end{tabular}




\begin{tabular}{|c|c|c|c|c|}
\hline \multirow[t]{2}{*}{ DESCRIÇÃOO } & \multirow[t]{2}{*}{ ESPECIFICAÇÃO } & \multirow[t]{2}{*}{ V.U. } & \multicolumn{2}{|c|}{$\begin{array}{l}\text { MANUTENÇÃO } \\
\text { P. ESTÁVEL } \\
\text { ANO } 8 \text { AO } 16\end{array}$} \\
\hline & & & Qtde. & TOTAL \\
\hline Fungicida & $\mathrm{R} \$ / \mathrm{kg}$ & 17,92 & 12,00 & 215,04 \\
\hline Inseticida & R\$/litro & 18,78 & 2,40 & 45,07 \\
\hline Formicida & $\mathrm{R} \$ / \mathrm{kg}$ & 8,10 & 0,50 & 4,05 \\
\hline Isca p/ Mosca & R\$/litro & 0,64 & 37,08 & 23,73 \\
\hline \multicolumn{5}{|l|}{ C3. Herbicidas } \\
\hline Pós Emergente & $\mathrm{R} \$$ /litro & 11,26 & 4,20 & 47,29 \\
\hline Subtotal C & & & & $1.540,32$ \\
\hline \multicolumn{5}{|l|}{$D$-ADMINISTRACÃO } \\
\hline Viagens & $\%$ Subtotal $(A+B+C)$ & $2,00 \%$ & 1,00 & 73,69 \\
\hline Assitência Técnica & $\%$ Subtotal $(\mathrm{A}+\mathrm{B}+\mathrm{C})$ & $2,00 \%$ & 1,00 & 73,69 \\
\hline Contabil./Escritório & $\%$ Subtotal $(A+B+C)$ & $2,00 \%$ & 1,00 & 73,69 \\
\hline M.O Administrativa & $\%$ Subtotal $(A+B+C)$ & $1,50 \%$ & 1,00 & 55,27 \\
\hline Consev./Deprec. Benf. & $\%$ Subtotal $(A+B+C)$ & $1,00 \%$ & 1,00 & 36,85 \\
\hline Impostos/ Taxas & $\%$ Receita & $3,00 \%$ & 1,00 & 149,31 \\
\hline Comercialização & $\%$ Receita & $2,90 \%$ & 1,00 & 144,33 \\
\hline Subtotal D & & & & 606,83 \\
\hline \multicolumn{4}{|l|}{ Custo Total (RS/ha/ano) } & $4.291,48$ \\
\hline \multicolumn{4}{|l|}{ Receita (R\$/ha/ano) } & $4.977,00$ \\
\hline \multicolumn{4}{|l|}{ Receita líquida por hectare } & 685,52 \\
\hline
\end{tabular}


Tabela A2 : Custos de produção por hectare, na propriedade $A$, em $R \$$, referentes a safra e 97/98, valores corrigidos em $R \$$ - janeiro/2001 .

\begin{tabular}{|c|c|c|c|c|}
\hline DESCRIÇÃO & ESPECIFICAÇÃO & \multicolumn{3}{|c|}{$1997 / 98$} \\
\hline A-OPERAÇÕES MECANIZ. & & V.U. & Qtde. & TOTAL \\
\hline \multicolumn{5}{|l|}{ A1. Preparo do Solo } \\
\hline Calagem & HM Tp $65 \mathrm{cv} .4 \times 2+$ distr. Calcário $2,3 \mathrm{~m}^{3}$ & 15,72 & 0,50 & 7,86 \\
\hline \multicolumn{5}{|l|}{ A2. Tratos Culturais } \\
\hline Pulverização (1x) & Bomba costal & 18,20 & 1,00 & 18,20 \\
\hline Roçagem $(2 x)$ & HM Tp 65 cv $4 \times 2+$ roçad. Hidraúlica & 15,72 & 5,00 & 78,60 \\
\hline Combate à Mosca $(2 \mathrm{x})$ & HM Tp $65 \mathrm{cv} .4 \times 2+$ pulv. 4001 & 16,05 & 4,20 & 67,41 \\
\hline Distribuição de esterco de curral & HM Tp 65 cv. $4 \times 2+$ carreta & 21,55 & 8,50 & 183,17 \\
\hline Adubação (2x) NPK 20-05-20 & HM Tp $65 \mathrm{cv} .4 \times 2+$ adubadora & 20,40 & 3,00 & 61,20 \\
\hline \multicolumn{5}{|l|}{ A3. Colheita } \\
\hline Colheita & HM Tp $65 \mathrm{cv} .4 \times 2+$ carreta & 17,36 & 5,00 & 86,80 \\
\hline Subtotal A & & & & 503,24 \\
\hline \multicolumn{5}{|l|}{ B-OPERACÕES MANUAIS } \\
\hline \multicolumn{5}{|l|}{ B1. Preparo do solo } \\
\hline Calagem & Homem-dia & 18,20 & 0,2 & 3,64 \\
\hline \multicolumn{5}{|l|}{ B2. Tratos Culturais } \\
\hline Adubação (2x) & Homem-dia & 18,20 & 0,40 & 7,28 \\
\hline Poda de Limpeza & Homem-dia & 18,20 & 10,00 & 182,0 \\
\hline Combate à Formiga ( $8 \mathrm{x})$ & Homem-dia & 18,20 & 0,60 & 10,92 \\
\hline Limpeza pomar /Podas & Homem-dia & 18,20 & 1,20 & 21,84 \\
\hline \multicolumn{5}{|l|}{ B3. Colheita } \\
\hline Colheita & Empreita (cx 40,8 kg) & 0,80 & 395.2 & 316,16 \\
\hline Subtotal B & & & & 541,84 \\
\hline \multicolumn{5}{|l|}{ C-INSUMOS } \\
\hline \multicolumn{5}{|l|}{ C1. Fertilizantes $\left({ }^{*}\right)$} \\
\hline Calcário & $\mathrm{R} \$ /$ ton & 29,15 & 1,00 & 29,15 \\
\hline NPK 20-05-20 & $\mathrm{R} \$ /$ ton & 382,45 & 0,18 & 68,84 \\
\hline Esterco de curral & $\mathrm{R} \$$ /ton & 72,35 & 20,00 & 1447,00 \\
\hline \multicolumn{5}{|l|}{ C2. Fitossanitário } \\
\hline Inseticida & R\$/litro & 14,77 & 2,00 & 29,54 \\
\hline Formicida & $\mathrm{R} \$ / \mathrm{kg}$ & 9,46 & 0,40 & 3,78 \\
\hline $\begin{array}{l}\text { Subtotal C } \\
D-A D M I N I S T R A C A O O\end{array}$ & & & & $1.578,31$ \\
\hline Comercialização & $\%$ Receita & $4,0 \%$ & 1,00 & 144,33 \\
\hline Subtotal D & & & & 144,33 \\
\hline \multicolumn{4}{|l|}{ Custo Total (RS/ha/ano) } & $2.767,72$ \\
\hline \multicolumn{4}{|l|}{ Receita (R\$/ha/ano) } & $2.462,10$ \\
\hline \multicolumn{4}{|l|}{ Receita líquida por hectare } & $-305,62$ \\
\hline
\end{tabular}


Tabela A3: Custos de produção por hectare, na propriedade $\mathrm{A}$, em $\mathrm{R} \$$, referentes a safra e 98/99, valores corrigidos em R\$ - janeiro/2001 .

\begin{tabular}{|c|c|c|c|c|}
\hline DESCRIÇÃO & ESPECIFICAÇÃO & \multicolumn{3}{|c|}{$1998 / 99$} \\
\hline A- OPERACÕ ES MECANIZ. & & V.U. & Qtde. & TOTAL \\
\hline \multicolumn{5}{|l|}{ A1. Preparo do Solo } \\
\hline Calagem & HM Tp $65 \mathrm{cv} .4 \times 2+$ distr. Calcário $2,3 \mathrm{~m}^{3}$ & 0 & 0 & 0 \\
\hline \multicolumn{5}{|l|}{ A2. Tratos Culturais } \\
\hline Pulverização (lx) & Bomba costal & 14,52 & 1,00 & 14,52 \\
\hline Roçagem $(2 x)$ & HM Tp $65 \mathrm{cv} .4 \times 2$ + roçad. Hidraúlica & 13,07 & 5,00 & 65,35 \\
\hline Combate à Mosca $(2 \mathrm{x})$ & HM Tp 65 cv. $4 \times 2+$ pulv. 4001 & 13,44 & 4,20 & 56,45 \\
\hline Distribuição de esterco de curral & HM Tp 65 cv $4 \times 2+$ carreta & 19,17 & 8,50 & 162,94 \\
\hline Adubação (2x) NPK 20-05-20 & HM Tp $65 \mathrm{cv} .4 \times 2+$ adubadora & 18,40 & 3,00 & 55,20 \\
\hline \multicolumn{5}{|l|}{ A3. Colheita } \\
\hline Colheita & HM Tp $65 \mathrm{cv} .4 \times 2+$ carreta & 14,45 & 5,00 & 72,25 \\
\hline Subtotal A & & & & 426,71 \\
\hline \multicolumn{5}{|l|}{ B-OPERACOOES MANUAIS } \\
\hline \multicolumn{5}{|l|}{ B1. Preparo do solo } \\
\hline Calagem & Homem-dia & 0 & & 0 \\
\hline \multicolumn{5}{|l|}{ B2. Tratos Culturais } \\
\hline Adubação $(2 \mathrm{x})$ & Homem-dia & 14,52 & 0,40 & 5,81 \\
\hline Poda de Limpeza & Homem-dia & 14,52 & 10,00 & 145,20 \\
\hline Combate à Formiga $(8 \mathrm{x})$ & Homem-dia & 14,52 & 0,60 & 8,71 \\
\hline Limpeza pomar /Podas & Homem-dia & 14,52 & 1,20 & 17,42 \\
\hline \multicolumn{5}{|l|}{ B3. Colheita } \\
\hline Colheita & Empreita (cx 40,8 kg) & 0,60 & 428,6 & 257.16 \\
\hline Subtotal B & & & & 434,30 \\
\hline \multicolumn{5}{|l|}{ C-INSUMOS } \\
\hline \multicolumn{5}{|l|}{ C1. Fertilizantes $\left(^{*}\right)$} \\
\hline Calcário & $\mathrm{R} \$$ /ton & & & \\
\hline NPK $20-05-20$ & $\mathrm{R} \$$ /ton & 314,56 & 0,18 & 56,52 \\
\hline Esterco de curral & $\mathrm{R} \$ /$ ton & 56,78 & 20,00 & 1135,60 \\
\hline \multicolumn{5}{|l|}{ C2. Fitossanitário } \\
\hline Inseticida & R\$/litro & 13,21 & 2,00 & 26,42 \\
\hline Formicida & $\mathrm{R} \$ / \mathrm{kg}$ & 8,98 & 0,30 & 2,69 \\
\hline $\begin{array}{l}\text { Subtotal C } \\
D \text { - ADMINISTRACAO }\end{array}$ & & & & $1.221,23$ \\
\hline Comercialização & $\%$ Receita & $5,0 \%$ & 1,00 & 118,95 \\
\hline Subtotal D & & & & 118,95 \\
\hline \multicolumn{3}{|l|}{ Custo Total (RS/ha/ano) } & & $2.201,19$ \\
\hline \multicolumn{3}{|l|}{ Receita (R\$/ha/ano) } & & $2.378,95$ \\
\hline \multicolumn{3}{|l|}{ Receita líquida por hectare } & & 177,76 \\
\hline
\end{tabular}


Tabela A4: Custos de produção por hectare, na propriedade A, em R\$, referentes a safra e 99/00, valores corrigidos em $\mathrm{R} \$$ - janeiro/2001.

\begin{tabular}{|c|c|c|c|c|}
\hline DESCRIÇÃO & ESPECIFICAÇÃO & \multicolumn{3}{|c|}{$1999 / 00$} \\
\hline A- OPERACÕESMECANIZ. & & V.U. & Qtde. & TOTAL \\
\hline \multicolumn{5}{|l|}{ A1. Preparo do Solo } \\
\hline Calagem & HM Tp $65 \mathrm{cv} 4 \times 2+$ distr. Calcário $2,3 \mathrm{~m}^{3}$ & 0 & 0 & 0 \\
\hline \multicolumn{5}{|l|}{ A2. Tratos Culturais } \\
\hline Pulverização $(1 \mathrm{x})$ & Bomba costal & 15,00 & 1,00 & 15,00 \\
\hline Roçagem $(2 \mathrm{x})$ & HM Tp $65 \mathrm{cv} .4 \times 2+$ roçad. Hidraúlica & 14,40 & 5,00 & 72,00 \\
\hline Combate à Mosca $(2 \mathrm{x})$ & HM Tp $65 \mathrm{cv} .4 \times 2+$ pulv. 4001 & 14,82 & 4,20 & 62,24 \\
\hline Distribuição de esterco de curral & HM Tp $65 \mathrm{cv} .4 \times 2+$ carreta & 20.68 & 8,50 & 175,78 \\
\hline Adubação (2x) NPK 20-05-20 & HM Tp $65 \mathrm{cv} 4 \times 2+$ adubadora & 19,45 & 3,00 & 58,35 \\
\hline \multicolumn{5}{|l|}{ A3. Colheita } \\
\hline Colheita & HM Tp $65 \mathrm{cv} 4 \times 2+$ carreta & 14,82 & 5,00 & 74,10 \\
\hline Subtotal $A$ & & & & $\mathbf{4 5 7 , 4 7}$ \\
\hline \multicolumn{5}{|l|}{ B-OPERACÕES MANUAIS } \\
\hline \multicolumn{5}{|l|}{ B1. Preparo do solo } \\
\hline Calagem & Homem-dia & 0 & 0 & 0 \\
\hline \multicolumn{5}{|l|}{ B2. Tratos Culturais } \\
\hline Adubação $(2 \mathrm{x})$ & Homem-dia & 15,00 & 0,40 & 6,00 \\
\hline Poda de Limpeza & Homem-dia & 15,00 & 10.00 & 150,00 \\
\hline Combate à Formiga $(8 \mathrm{x})$ & Homem-dia & 15,00 & 0,60 & 9,00 \\
\hline Limpeza pomar/Podas & Homem-dia & 15,00 & 1,20 & 18,00 \\
\hline \multicolumn{5}{|l|}{ B3. Colheita } \\
\hline Colheita & Empreita (cx 40,8 kg) & 0,75 & 580,6 & 435,45 \\
\hline Subtotal B & & & & 618,45 \\
\hline \multicolumn{5}{|l|}{ C-INSUMOS } \\
\hline \multicolumn{5}{|l|}{ C1. Fertilizantes $\left({ }^{*}\right)$} \\
\hline Calcário & $\mathrm{R} \$ /$ ton & & & \\
\hline NPK 20-05-20 & $\mathrm{R} \$ /$ ton & 322,44 & 0,18 & 58,04 \\
\hline Esterco de curral & $\mathrm{R} \$ /$ ton & 48,00 & 20,00 & 960,00 \\
\hline \multicolumn{5}{|l|}{ C2. Fitossanitário } \\
\hline Inseticida & R\$/litro & 0,0 & 0,0 & 0,0 \\
\hline Formicida & $\mathrm{R} \$ / \mathrm{kg}$ & 10,50 & 0,20 & 2,10 \\
\hline $\begin{array}{l}\text { Subtotal C } \\
D \text { - ADMINISTRACAOO }\end{array}$ & & & & $1.020,14$ \\
\hline Comercialização & $\%$ Receita & $8,0 \%$ & 1,00 & 195,56 \\
\hline Subtotal D & & & & 195,56 \\
\hline \multicolumn{3}{|l|}{ Custo Total (RS/ha/ano) } & & $2.291,62$ \\
\hline \multicolumn{3}{|l|}{ Receita (R\$/ha/ano) } & & $2.444,49$ \\
\hline \multicolumn{3}{|l|}{ Receita líquida por hectare } & & 152,87 \\
\hline
\end{tabular}


Tabela A5: Custos de produção por hectare, na propriedade B, em $\mathrm{R}$, referentes a safra 97/98. Valores corrigidos em R\$ - janeiro/2001.

\begin{tabular}{|c|c|c|c|c|}
\hline DESCRICCÃO & ESPECIFICACÃO & \multicolumn{3}{|c|}{$1997 / 98$} \\
\hline A- OPERACÕES MECANIZ. & & V.U. & Qtde. & TOTAL \\
\hline \multicolumn{5}{|l|}{ A1. Preparo do Solo } \\
\hline Calagem & HM Tp 65 cy. $4 \times 2+$ distr. Calcário $2,3 \mathrm{~m}^{3}$ & 0 & 0 & 0 \\
\hline \multicolumn{5}{|l|}{ A2. Tratos Culturais } \\
\hline Pulverização (1x) & Bomba costal & 18,20 & 1,00 & 18,20 \\
\hline Roçagem $(2 x)$ & HM Tp $65 \mathrm{cv} .4 \times 2+$ roçad. Hidraúlica & 15,72 & 5,00 & 78,60 \\
\hline Combate à Mosca (2x) & HM Tp 65 cv. $4 \times 2+$ pulv. 4001 & 16,05 & 4,20 & 67,41 \\
\hline Distribuição de cama de frango & HM Tp $65 \mathrm{cv} .4 \times 2+$ carreta & 21,55 & 3,50 & 75,42 \\
\hline Adubação (3x) NPK 20-05-20 & HM Tp $65 \mathrm{cv} .4 \times 2+$ adubadora & 20,40 & 4,50 & 91.80 \\
\hline DESCRIÇÃO & ESPECIFICAÇÃO & \multicolumn{3}{|c|}{$1997 / 98$} \\
\hline & & V.U. & Qtde. & TOTAL \\
\hline \multicolumn{5}{|l|}{ A3. Colheita } \\
\hline Colheita & HM Tp $65 \mathrm{cv} .4 \times 2+$ carreta & 17,36 & 5,00 & 86.80 \\
\hline Subtotal A & & & & 418,23 \\
\hline \multicolumn{5}{|l|}{ B-OPERACCÕES MANUAIS } \\
\hline \multicolumn{5}{|l|}{ B1. Preparo do solo } \\
\hline Calagem & Homem-dia & 18,20 & 0,2 & 3,64 \\
\hline \multicolumn{5}{|l|}{ B2. Tratos Culturais } \\
\hline Adubação $(3 \mathrm{x})$ & Homem-dia & 18,20 & 0,40 & 7,28 \\
\hline Poda de Limpeza & Homem-dia & 18,20 & 10,00 & 182.0 \\
\hline Combate à Formiga $(8 \mathrm{x})$ & Homem-dia & 18,20 & 0,90 & 16.38 \\
\hline Limpeza pomar/Podas & Homem-dia & 18,20 & 1,20 & 21.84 \\
\hline \multicolumn{5}{|l|}{ B3. Colheita } \\
\hline Colheita & Empreita (cx 40,8 kg) & 0,80 & 483,0 & 386.40 \\
\hline Subtotal B & & & & 613,90 \\
\hline \multicolumn{5}{|l|}{$C-I N S U M O S$} \\
\hline \multicolumn{5}{|l|}{ C1. Fertilizantes $\left(^{*}\right)$} \\
\hline Calcário & $\mathrm{R} \$ /$ ton & 0 & 0 & 0 \\
\hline NPK 20-05-20 & $\mathrm{R} \$ /$ ton & 382,45 & 0,25 & 95.61 \\
\hline Cama de frango & $\mathrm{R} \$ /$ ton & 54,60 & 10,00 & 546.00 \\
\hline \multicolumn{5}{|l|}{ C2. Fitossanitário } \\
\hline Inseticida & R\$/litro & 14,77 & 2,00 & 29.54 \\
\hline Formicida & $\mathrm{R} \$ / \mathrm{kg}$ & 9,46 & 0,40 & 3,78 \\
\hline Subtotal C & & & & 674,93 \\
\hline \multicolumn{5}{|l|}{ D- ADMINISTRAÇÃO } \\
\hline Comercialização & $\%$ Receita & $3,0 \%$ & 1,00 & 94.91 \\
\hline Subtotal D & & & & 94,91 \\
\hline Custo Total (RS/ha/ano) & & & & $1.801,97$ \\
\hline Receita (R\$/ha/ano) & & & & $3.163,55$ \\
\hline Receita líquida por hectare & & & & $1.361,68$ \\
\hline
\end{tabular}


Tabela A6: Custos de produção por hectare, na propriedade B, em R\$, referentes a safra 98/99, valores corrigidos em R\$ - janeiro/2001 .

\begin{tabular}{|c|c|c|c|c|}
\hline DESCRICCÃO & ESPECIFICAÇÃO & \multicolumn{3}{|c|}{ 1998/99 } \\
\hline A-OPERACÕES MECANIZ. & & V.U. & Qtde. & TOTAL \\
\hline \multicolumn{5}{|l|}{ A1. Preparo do Solo } \\
\hline Calagem & HM Tp $65 \mathrm{cv} .4 \times 2+$ distr. Calcário $2,3 \mathrm{~m}^{3}$ & 14,12 & 0,50 & 7,06 \\
\hline \multicolumn{5}{|l|}{ A2. Tratos Culturais } \\
\hline Pulverização (1x) & Bomba costal & 14,52 & 1,00 & 14,52 \\
\hline Roçagem $(2 x)$ & HM Tp 65 cv. $4 \times 2+$ roçad Hidraúlica & 13,07 & 5,00 & 65,35 \\
\hline Combate à Mosca $(2 \mathrm{x})$ & HM Tp 65 cv $4 \times 2+$ pulv. 4001 & 13,44 & 4,20 & 56,45 \\
\hline Distribuição de cama de frango & HM Tp 65 cv. $4 \times 2+$ carreta & 0 & 0 & 0 \\
\hline Adubação (3x) NPK 20-05-20 & HM Tp $65 \mathrm{cv} .4 \times 2+$ adubadora & 18,40 & 4,5 & 82,80 \\
\hline DESCRIĈÃO & ESPECIFICACÃ̃O & \multicolumn{3}{|c|}{$1998 / 99$} \\
\hline & & V.U. & Qtde. & TOTAL \\
\hline \multicolumn{5}{|l|}{ A3. Colheita } \\
\hline Colheita & HM Tp 65 cv $4 \times 2+$ carreta & 14,45 & 5,00 & 72,25 \\
\hline Subtotal A & & & & 298,43 \\
\hline \multicolumn{5}{|l|}{ B-OPERAÇÓES MLANUAIS } \\
\hline \multicolumn{5}{|l|}{ B1. Preparo do solo } \\
\hline Calagem & Homem-dia & 17,12 & 0,3 & 5,14 \\
\hline \multicolumn{5}{|l|}{ B2. Tratos Culturais } \\
\hline Adubação (3x) & Homem-dia & 14,52 & 0,40 & 5,81 \\
\hline Poda de Limpeza & Homem-dia & 14,52 & 10,00 & 145,20 \\
\hline Combate à Formiga $(8 \mathrm{x})$ & Homem-dia & 14,52 & 0,90 & 13,07 \\
\hline Limpeza pomar /Podas & Homem-dia & 14,52 & 1,20 & 17,42 \\
\hline \multicolumn{5}{|l|}{ B3. Colheita } \\
\hline Colheita & Empreita (cx 40,8 kg) & 0,60 & 462.0 & 277,20 \\
\hline Subtotal B & & & & 463,84 \\
\hline \multicolumn{5}{|l|}{$C-I N S U M O S$} \\
\hline \multicolumn{5}{|l|}{ C1. Fertilizantes $\left(^{*}\right)$} \\
\hline Calcário & $\mathrm{R} \$ /$ ton & 25,16 & 1,2 & 30,19 \\
\hline NPK $20-05-20$ & $\mathrm{R} \$ /$ ton & 314,56 & 0,25 & 78,64 \\
\hline Cama de frango & $\mathrm{R} \$ /$ ton & 0 & 0 & 0 \\
\hline \multicolumn{5}{|l|}{ C2. Fitossanitário } \\
\hline Inseticida & R\$/litro & 13,21 & 2,00 & 26,42 \\
\hline Formicida & $\mathrm{R} \$ \mathrm{~kg}$ & 8,98 & 0,30 & 2,69 \\
\hline Subtotal C & & & & 137,94 \\
\hline \multicolumn{5}{|l|}{ D- ADMINISTRAÇÃO } \\
\hline Comercialização & $\%$ Receita & $3,5 \%$ & 1,00 & 86,02 \\
\hline Subtotal D & & & & 86,02 \\
\hline Custo Total (RS/ha/ano) & & & & 986,23 \\
\hline Receita (R\$/ha/ano) & & & & $2.457,84$ \\
\hline Receita líquida por hectare & & & & $1.471,61$ \\
\hline
\end{tabular}


Tabela A7: Custos de produção por hectare, na propriedade B, em $\mathrm{R} \$$, referentes a safra 99/00, valores corrigidos em $\mathrm{R} \$$ - janeiro/2001 .

\begin{tabular}{|c|c|c|c|c|}
\hline DESCRIÇÃO & ESPECIFICAÇÃO & \multicolumn{3}{|c|}{$1999 / 00$} \\
\hline A-OPERAÇÕESMECANIZ. & & V.U. & Qtde. & TOTAL \\
\hline \multicolumn{5}{|l|}{ A1. Preparo do Solo } \\
\hline Calagem & HM Tp $65 \mathrm{cv} .4 \times 2+$ distr. Calcário $2,3 \mathrm{~m}^{3}$ & 0 & 0 & 0 \\
\hline \multicolumn{5}{|l|}{ A2. Tratos Culturais } \\
\hline Pulverização (1x) & Bomba costal & 15,00 & 1,00 & 15,00 \\
\hline Roçagem $(2 x)$ & HM Tp $65 \mathrm{cv} .4 \times 2+$ roçad. Hidraúlica & 14,40 & 5,00 & 72,00 \\
\hline Combate à Mosca $(2 \mathrm{x})$ & HM Tp 65 cv. $4 \times 2+$ pulv. 4001 & 14,82 & 4,20 & 62,24 \\
\hline Distribuição de cama de frango & HM Tp 65 cv $4 \times 2+$ carreta & 0 & 0 & 0 \\
\hline Adubação (3x) NPK 20-05-20 & HM Tp 65 cv. $4 \times 2+$ adubadora & 19,45 & 4,5 & 87,52 \\
\hline & & & & \\
\hline DESCRIĈ̃̃O & ESPECIFICAÇÃO & \multicolumn{3}{|c|}{$1999 / 00$} \\
\hline & & V.U. & Qtde. & TOTAL \\
\hline \multicolumn{5}{|l|}{ A3. Colheita } \\
\hline Colheita & HM Tp 65 cv. $4 \times 2+$ carreta & 14,82 & 5,00 & 74,10 \\
\hline Subtotal A & & & & 310,86 \\
\hline \multicolumn{5}{|l|}{$B$-OPERAÇÕES MANUAIS } \\
\hline \multicolumn{5}{|l|}{ B1. Preparo do solo } \\
\hline Calagem & Homem-dia & 0 & 0 & 0 \\
\hline \multicolumn{5}{|l|}{ B2. Tratos Culturais } \\
\hline Adubação (3x) & Homem-dia & 15,00 & 0,40 & 6,00 \\
\hline Poda de Limpeza & Homem-dia & 15,00 & 10,00 & 150,00 \\
\hline Combate à Formiga $(8 \mathrm{x})$ & Homem-dia & 15,00 & 0,90 & 13,50 \\
\hline Limpeza pomar /Podas & Homem-dia & 15,00 & 1,20 & 18,00 \\
\hline \multicolumn{5}{|l|}{ B3. Colheita } \\
\hline Colheita & Empreita (cx 40,8 kg) & 0,75 & 555,00 & 416,25 \\
\hline Subtotal B & & & & 603,75 \\
\hline \multicolumn{5}{|l|}{ C-INSUMOS } \\
\hline \multicolumn{5}{|l|}{ C1. Fertilizantes $\left(^{*}\right)$} \\
\hline Calcário & $\mathrm{R} \$ /$ ton & 0 & 0 & 0 \\
\hline NPK $20-05-20$ & $\mathrm{R} \$ /$ ton & 322,44 & 0,25 & 80,61 \\
\hline Cama de frango & $\mathrm{R} \$ /$ ton & 0 & 0 & 0 \\
\hline \multicolumn{5}{|l|}{ C2. Fitossanitário } \\
\hline Inseticida & R\$/litro & 0,0 & 0,0 & 0,0 \\
\hline Formicida & $\mathrm{R} \$ / \mathrm{kg}$ & 10,50 & 0,20 & 2,10 \\
\hline Subtotal C & & & & 82,71 \\
\hline \multicolumn{5}{|l|}{ D- ADMINISTRAÇÃO } \\
\hline Comercialização & $\%$ Receita & $5,0 \%$ & 1,00 & 86,58 \\
\hline Subtotal D & & & & 86,58 \\
\hline Custo Total (RS/ha/ano) & & & & $1.083,90$ \\
\hline Receita (R\$/ha/ano) & & & & $1.731,60$ \\
\hline Receita líquida por hectare & & & & 647,70 \\
\hline
\end{tabular}


Tabela A8: Custos de produção por hectare, na propriedade $\mathrm{C}$, em $\mathrm{R} \$$, referentes a safra 97/98, valores corrigidos em $R \$$ - janeiro/2001 .

\begin{tabular}{|c|c|c|c|c|}
\hline DESCRIÇÃOO & ESPECIFICAÇÃO & \multicolumn{3}{|c|}{$1997 / 98$} \\
\hline A-OPERAÇÕES MECANIZ. & & V.U. & Qtde. & TOTAL \\
\hline \multicolumn{5}{|l|}{ A1. Preparo do Solo } \\
\hline Calagem & HM Tp $65 \mathrm{cv} .4 \times 2+$ distr. Calcário $2,3 \mathrm{~m}^{3}$ & 0 & 0 & 0 \\
\hline \multicolumn{5}{|l|}{ A2. Tratos Culturais } \\
\hline Pulverização (lx) & Bomba costal & 18,20 & 1,00 & 18,20 \\
\hline Roçagem $(2 x)$ & HM Tp 65 cv. $4 \times 2+$ roçad. Hidraúlica & 15,72 & 5,00 & 78,60 \\
\hline Combate à Mosca $(2 \mathrm{x})$ & HM Tp 65 cv. $4 \times 2+$ pulv. 4001 & 16,05 & 4,20 & 67,41 \\
\hline Adubação (3x) NPK 20-05-20 & HM Tp 65 cv. $4 \times 2+$ adubadora & 20,40 & 4,5 & 91,80 \\
\hline Aplic de Herbicida (1x) & HM Tp 65 cv. $4 \times 2+$ pulv. Barras & 17,38 & 2,00 & 34,76 \\
\hline \multicolumn{5}{|l|}{ A3. Colheita } \\
\hline Colheita & HM Tp 65 cv. $4 \times 2+$ carreta & 17,36 & 5,00 & 86,80 \\
\hline Subtotal A & & & & 377,57 \\
\hline \multicolumn{5}{|l|}{ B-OPERAÇÕES MANUAIS } \\
\hline \multicolumn{5}{|l|}{ B1. Preparo do solo } \\
\hline Calagem & Homem-dia & 0 & 0 & 0 \\
\hline \multicolumn{5}{|l|}{ B2. Tratos Culturais } \\
\hline Adubação (3x) & Homem-dia & 18,20 & 0,40 & 7,28 \\
\hline Poda de Limpeza & Homem-dia & 18,20 & 10,00 & 182,0 \\
\hline Combate à Formiga $(8 \mathrm{x})$ & Homem-dia & 18,20 & 0,90 & 16,38 \\
\hline Limpeza pomar/Podas & Homem-dia & 18,20 & 1,20 & 21,84 \\
\hline \multicolumn{5}{|l|}{ B3. Colheita } \\
\hline Colheita & Empreita (cx 40,8 kg) & 0,80 & 460,56 & 368,45 \\
\hline Subtotal B & & & & 595,95 \\
\hline \multicolumn{5}{|l|}{ C-INSUMOS } \\
\hline \multicolumn{5}{|l|}{ C1. Fertilizantes $\left({ }^{*}\right)$} \\
\hline Calcário & $\mathrm{R} \$ /$ ton & 0 & 0 & 0 \\
\hline NPK 20-05-20 & R\$/ton & 382,45 & 0,25 & 95,61 \\
\hline \multicolumn{5}{|l|}{ C2. Fitossanitário } \\
\hline Inseticida & R\$/litro & 14,77 & 2,00 & 29,54 \\
\hline Formicida & $\mathrm{R} \$ \mathrm{~kg}$ & 9,46 & 0,40 & 3,78 \\
\hline \multicolumn{5}{|l|}{ C3. Herbicidas } \\
\hline Pós Emergente & $\mathrm{R} \$$ /litro & 10,77 & 1,82 & 19,60 \\
\hline Subtotal C & & & & 148,53 \\
\hline \multicolumn{5}{|l|}{ D-ADMINISTRACÃO } \\
\hline Comercialização & \% Receita & $3,0 \%$ & 1,00 & 78,34 \\
\hline Subtotal D & & & & 78,34 \\
\hline Custo Total (RS/ha/ano) & & & & $1.200,39$ \\
\hline Receita (R\$/ha/ano) & & & & $2.611,37$ \\
\hline Receita líquida por hectare & & & & $1.410,98$ \\
\hline
\end{tabular}


Tabela A9: Custos de produção por hectare, na propriedade $\mathrm{C}$, em $\mathrm{R} \$$, referentes a safra 98/99, valores corrigidos em $\mathrm{R} \$$ - janeiro/2001 .

\begin{tabular}{|c|c|c|c|c|}
\hline DESCRIÇÃO & ESPECIFICAÇÃO & \multicolumn{3}{|c|}{$1998 / 99$} \\
\hline A-OPERAÇÕESMECANIZ. & & V.U. & Qtde. & TOTAL \\
\hline \multicolumn{5}{|l|}{ A1. Preparo do Solo } \\
\hline Calagem & HM Tp 65 cv. $4 \times 2+$ distr. Calcário $2,3 \mathrm{~m}^{3}$ & 14,12 & 0,60 & 8,47 \\
\hline \multicolumn{5}{|l|}{ A2. Tratos Culturais } \\
\hline Pulverização (1x) & Bomba costal & 14,52 & 1,00 & 14,52 \\
\hline Roçagem $(2 x)$ & HM Tp $65 \mathrm{cv} .4 \times 2+$ roçad Hidraúlica & 13,07 & 5,00 & 65,35 \\
\hline Combate à Mosca $(2 \mathrm{x})$ & HM Tp $65 \mathrm{cv} .4 \times 2+$ pulv. 4001 & 13,44 & 4,20 & 56,45 \\
\hline Adubação (3x) NPK 20-05-20 & HM Tp 65 cv. $4 \times 2+$ adubadora & 18,40 & 4,5 & 82,80 \\
\hline Aplic de Herbicida $(1 \mathrm{x})$ & HM Tp $65 \mathrm{cv} .4 \times 2+$ pulv . Barras & 15,77 & 2,00 & 31,54 \\
\hline \multicolumn{5}{|l|}{ A3. Colheita } \\
\hline Colheita & HM Tp 65 cv. $4 \times 2+$ carreta & 14,45 & 5,00 & 72,25 \\
\hline Subtotal A & & & & 322,91 \\
\hline \multicolumn{5}{|l|}{ B-OPERACOEES MANUAIS } \\
\hline \multicolumn{5}{|l|}{ B1. Preparo do solo } \\
\hline Calagem & Homem-dia & 17,12 & 0,4 & 6,85 \\
\hline \multicolumn{5}{|l|}{ B2. Tratos Culturais } \\
\hline Adubação (3x) & Homem-dia & 14,52 & 0,40 & 5,81 \\
\hline Poda de Limpeza & Homem-dia & 14,52 & 10,00 & 145,20 \\
\hline Combate à Formiga $(8 \mathrm{x})$ & Homem-dia & 14,52 & 0,90 & 13,07 \\
\hline Limpeza pomar /Podas & Homem-dia & 14,52 & 1,20 & 17,42 \\
\hline \multicolumn{5}{|l|}{ B3. Colheita } \\
\hline Colheita & Empreita (cx 40,8 kg) & 0,60 & 430,26 & 258,16 \\
\hline Subtotal B & & & & 446,51 \\
\hline \multicolumn{5}{|l|}{$C$-INSUMOS } \\
\hline \multicolumn{5}{|l|}{ C1. Fertilizantes (*) } \\
\hline Calcário & $\mathrm{R} \$ /$ ton & 25,16 & 1,5 & 37,74 \\
\hline NPK $20-05-20$ & $\mathrm{R} \$ /$ ton & 314,56 & 0,25 & 78,64 \\
\hline \multicolumn{5}{|l|}{ C2. Fitossanitário } \\
\hline Inseticida & R\$/litro & 13,21 & 2,00 & 26,42 \\
\hline Formicida & $\mathrm{R} \$ / \mathrm{kg}$ & 8,98 & 0,30 & 2,69 \\
\hline \multicolumn{5}{|l|}{ C3. Herbicidas } \\
\hline Pós Emergente & R\$/itro & 10,95 & 1,82 & 19,93 \\
\hline Subtotal C & & & & 165,42 \\
\hline \multicolumn{5}{|l|}{ D- ADMINISTRAÇÃO } \\
\hline Comercialização & $\%$ Receita & $3,5 \%$ & 1,00 & 68,37 \\
\hline Subtotal D & & & & 68,37 \\
\hline & & & & \\
\hline Custo Total (RS/ha/ano) & & & & $1.003,21$ \\
\hline Receita (R\$/ha/ano) & & & & $1.953,38$ \\
\hline Receita líquida por hectare & & & & 950,17 \\
\hline
\end{tabular}


Tabela A10: Custos de produção por hectare, na propriedade $C$, em $R \$$, referentes a safra 99/00, valores corrigidos em R\$ - janeiro/2001.

\begin{tabular}{|c|c|c|c|c|}
\hline DESCRICCÃO & ESPECIFICACCÃO & \multicolumn{3}{|c|}{$1999 / 00$} \\
\hline A- OPERAÇÕES MECANIZ. & & V.U. & Qtde. & TOTAL \\
\hline \multicolumn{5}{|l|}{ A1. Preparo do Solo } \\
\hline Calagem & HM Tp 65 cv. $4 \times 2+$ distr. Calcário $2,3 \mathrm{~m}^{3}$ & 0 & 0 & 0 \\
\hline \multicolumn{5}{|l|}{ A2. Tratos Culturais } \\
\hline Pulverização (1x) & Bomba costal & 15,00 & 1,00 & 15,00 \\
\hline Roçagem $(2 \mathrm{x})$ & HM Tp $65 \mathrm{cv} .4 \times 2+$ roçad. Hidraúlica & 14,40 & 5.00 & 72,00 \\
\hline Combate à Mosca $(2 \mathrm{x})$ & HM Tp 65 cv. $4 \times 2+$ pulv. 4001 & 14,82 & 4.20 & 62,24 \\
\hline Adubação (3x) NPK 20-05-20 & HM Tp 65 cv. $4 \times 2+$ adubadora & 19,45 & 4.5 & 87,52 \\
\hline Aplic. de Herbicida (1x) & HM Tp 65 cv. $4 \times 2+$ pulv. Barras & $0 \ldots$ & 0 & 0 \\
\hline \multicolumn{5}{|l|}{ A3. Colheita } \\
\hline Colheita & HM Tp $65 c v .4 \times 2+$ carreta & 14,82 & 5.00 & 74,10 \\
\hline Subtotal A & & & & 310,86 \\
\hline \multicolumn{5}{|l|}{ B-OPERACÕES MANUAIS } \\
\hline \multicolumn{5}{|l|}{ B1. Preparo do solo } \\
\hline Calagem & Homem-dia & 0 & 0 & 0 \\
\hline \multicolumn{5}{|l|}{ B2. Tratos Culturais } \\
\hline Adubação (3x) & Homem-dia & 15,00 & 0.40 & 6,00 \\
\hline Poda de Limpeza & Homem-dia & 15,00 & 10,00 & 150,00 \\
\hline Combate à Formiga $(8 \mathrm{x})$ & Homem-dia & 15,00 & 0.90 & 13,50 \\
\hline Limpeza pomar/Podas & Homem-dia & 15,00 & 1.20 & 18,00 \\
\hline \multicolumn{5}{|l|}{ B3. Colheita } \\
\hline Colheita & Empreita (cx 40,8 kg) & 0,75 & 402,99 & 302,24 \\
\hline \multirow[t]{2}{*}{ Subtotal B } & & & & 489,74 \\
\hline & & V.U. & Qtde. & TOTAL \\
\hline \multicolumn{5}{|l|}{ C-INSUMOS } \\
\hline \multicolumn{5}{|l|}{ C1. Fertilizantes $\left(^{*}\right)$} \\
\hline Calcário & $\mathrm{R} \$ /$ ton & 0 & 0 & 0 \\
\hline NPK 20-05-20 & R\$/ton & 322,44 & 0,25 & 80,61 \\
\hline \multicolumn{5}{|l|}{ C2. Fitossanitário } \\
\hline Inseticida & R\$/litro & 0,0 & 0,0 & 0,0 \\
\hline Formicida & $\mathrm{R} \$ / \mathrm{kg}$ & 10,50 & 0.20 & 2,10 \\
\hline \multicolumn{5}{|l|}{ C3. Herbicidas } \\
\hline Pós Emergente & R\$/litro & 0 & 0 & 0 \\
\hline Subtotal C & & & & 82,71 \\
\hline \multicolumn{5}{|l|}{ D-ADMINISTRAÇÃO } \\
\hline Comercialização & $\%$ Receita & $4,0 \%$ & 1,00 & 48,52 \\
\hline Subtotal D & & & & 48,52 \\
\hline Custo Total (RS/ha/ano) & & & & 931,83 \\
\hline Receita (R\$/ha/ano) & & & & $1.213,00$ \\
\hline Receita líquida por hectare & & & & 281,17 \\
\hline
\end{tabular}


Tabela A11: Custos de produção por hectare, na propriedade $D$, em $R \$$, referente a safra 97/98, valores corrigidos em R\$ - janeiro/2001.

\begin{tabular}{|c|c|c|c|c|}
\hline DESCRIÇÃO & ESPECIFICAÇÃO & V.U. & \multicolumn{2}{|c|}{$1997 / 98$} \\
\hline & & & Qtde. & TOTAL \\
\hline \multicolumn{5}{|c|}{ A. OPERACOES MECANIZADAS } \\
\hline \multicolumn{5}{|c|}{\begin{tabular}{|l|l} 
A1. Preparo do Solo & \\
\end{tabular}} \\
\hline Calagem & HM Tp 70cv. $4 \times 2+$ distr. Calcário $2,3 \mathrm{~m}^{3}$ & 25,50 & 0,50 & 12,75 \\
\hline \multicolumn{5}{|l|}{ A2. Tratos Culturais } \\
\hline Pulverização (2x) & HM Tp 70cv. $4 \times 2+$ atomizador 20001 & 23,96 & 4,20 & 100,63 \\
\hline Roçagem (2x) & HM Tp $70 \mathrm{cv} .4 \times 2+$ rocad . Hidraúlica & 21,32 & 3,00 & 63,96 \\
\hline Aplic. de Herbicida ( $1 \mathrm{x}$ ) & HM Tp 70cv.4x2+pulv. Barras & 27,06 & 2,40 & 64,94 \\
\hline Adubação foliar ( $1 \mathrm{x})$ & HM Tp $70 \mathrm{cv} .4 \times 2+$ atomizador 20001 & 33,55 & 3,30 & 110,05 \\
\hline Adubação (4x) & HM Tp 70cv.4x2+ adubadora & 28,52 & 3,20 & 91,26 \\
\hline \multicolumn{5}{|l|}{ A3. Colheita } \\
\hline Colheita & HM Tp 70cv. $4 \times 2+$ carreta & 24,86 & 5,00 & 124,30 \\
\hline Subtotal $A$ & & & & 567,89 \\
\hline \multicolumn{5}{|l|}{$\begin{array}{l}\text { B-OPERAÇOES MANUAIS } \\
\text { B1. Preparo do solo }\end{array}$} \\
\hline Calagem & Homem-dia & 18,96 & 0,23 & 4,36 \\
\hline \multicolumn{5}{|l|}{ B2. Tratos Culturais } \\
\hline Adubação (4x) & Homem-dia & 17,46 & 0,75 & 13,09 \\
\hline Poda de Limpeza & Homem-dia & 17,15 & 9,00 & 154,35 \\
\hline Combate à Formiga $(8 \mathrm{x})$ & Homem-dia & 18,86 & 0,80 & 15,09 \\
\hline Limpeza pomar/Podas & Homem-dia & 18,86 & 1,35 & 25,46 \\
\hline \multicolumn{5}{|l|}{ B3. Colheita } \\
\hline Colheita & Empreita (cx 40,8 kg) & 1,00 & 399,99 & 399,99 \\
\hline Subtotal B & & & & 612,34 \\
\hline \multicolumn{5}{|l|}{$\begin{array}{l}C \text { - INSUMOS (CIF) } \\
\left.\text { C1. Fertilizantes ( }{ }^{(}\right)\end{array}$} \\
\hline Calcário & $\mathrm{R} \$$ /ton & 25,66 & 1,00 & 25,66 \\
\hline Superfosfato Simples & $\mathrm{R} \$$ /ton & 196,04 & 0,25 & 49,01 \\
\hline NPK 20-00-20 & $\mathrm{R} \$ /$ ton & 280,20 & 0,30 & 84,06 \\
\hline Uréia & $\mathrm{RS/ton}$ & 341,38 & 0,02 & 6,83 \\
\hline Sulfato de Zinco & $\mathrm{R} \$ / \mathrm{Kg}$ & 2,00 & 9,00 & 18,00 \\
\hline Sulfato de Manganês & $\mathrm{R} \$ / \mathrm{Kg}$ & 1,90 & 6,00 & 11,4 \\
\hline Ácido Bórico & $\mathrm{RS/Kg}$ & 2,78 & 3,00 & 8,34 \\
\hline C2. Fitossanitário & $\mathrm{R} \$ / \mathrm{Kg}$ & & & \\
\hline Acaricida & $\mathrm{R} \$$ /litro & 39,28 & 4,20 & 164,98 \\
\hline Fungicida & $\mathrm{R} \$ \mathbf{k g}$ & 17,92 & 3,00 & 53,76 \\
\hline Formicida & $\mathrm{R} \$ \mathrm{~kg}$ & 8,10 & 0,50 & 4,05 \\
\hline \multicolumn{5}{|l|}{ C3. Herbicidas } \\
\hline Pós Emergente & R\$/litro & 11,26 & 4,20 & 47,29 \\
\hline Subtotal C & & & & 473,38 \\
\hline \multicolumn{5}{|l|}{ D-ADMINISTRACAOO } \\
\hline Assitência Técnica & $\%$ Subtotal $(A+B+C)$ & $4,00 \%$ & 1,00 & 66,19 \\
\hline Contabil./ Escritório + Comerc. & $\%$ Subtotal $(A+B+C)$ & $12,9 \%$ & 1,00 & 213,35 \\
\hline Consev. Deprec. Benf. & $\%$ Subtotal $(A+B+C)$ & $3,00 \%$ & 1,00 & 66,22 \\
\hline Subtotal D & & & & $\mathbf{3 4 5 , 7 4}$ \\
\hline \multicolumn{4}{|l|}{ Custo Total (RS/ha/ano) } & $1,999,37$ \\
\hline \multicolumn{4}{|l|}{ Receita (R\$/ha/ano) } & $2.366,07$ \\
\hline \multicolumn{4}{|l|}{ Receita líquida por hectare } & 336,70 \\
\hline
\end{tabular}


Tabela A12: Custos de produção por hectare, na propriedade $D$, em $R \$$, referente a safra 98/99, valores corrigidos em R\$ - janeiro/2001.

\begin{tabular}{|c|c|c|c|c|}
\hline \multirow{2}{*}{ DESCRIÇÃO } & \multirow{2}{*}{ ESPECIFICAÇĀO } & \multirow{2}{*}{ V.U. } & \multicolumn{2}{|c|}{$1998 / 99$} \\
\hline & & & Qtde. & TOTAL \\
\hline \multicolumn{5}{|c|}{ A. OPERAÇÕES MECANIZADAS } \\
\hline \multicolumn{5}{|c|}{\begin{tabular}{|l|l} 
A1. Preparo do Solo & \\
\end{tabular}} \\
\hline Calagem & HM Tp $70 \mathrm{cv} .4 \times 2+$ distr. Calcário $2,3 \mathrm{~m}^{3}$ & 22,56 & 0,50 & 11,28 \\
\hline A2. Tratos Culturais & & & & 0 \\
\hline Pulverização $(2 \mathrm{x})$ & HM Tp $70 \mathrm{cv} .4 \times 2+$ atomizador 20001 & 21,64 & 5,20 & 112,53 \\
\hline Rocagem $(2 x)$ & HM Tp $70 \mathrm{cv} .4 \times 2+$ roçad. Hidraúlica & 21,32 & 3,00 & 63,96 \\
\hline Adubação foliar (lx) & HM Tp 70cv. $4 \times 2+$ atomizador 20001 & 31,12 & 3,30 & 102,70 \\
\hline Adubação (4x) & HM Tp $70 \mathrm{cv} .4 \times 2+$ adubadora & 26,16 & 3,20 & 83,71 \\
\hline A3. Colheita & & & & 0 \\
\hline Colheita & HM Tp 70 cv $4 \times 2+$ carreta & 22,45 & 5,00 & 112,25 \\
\hline Subtotal $A$ & & & & 486,43 \\
\hline \multicolumn{5}{|l|}{$\begin{array}{l}\text { B-OPERAÇÕES MANUAIS } \\
\text { B1. Preparo do solo }\end{array}$} \\
\hline Calagem & Homem-dia & 18,96 & 0,23 & 4,36 \\
\hline B2. Tratos Culturais & & & & 0 \\
\hline Adubação (4x) & Homem-dia & 17,46 & 0,75 & 13,09 \\
\hline Poda de Limpeza & Homem-dia & 16,21 & 8,5 & 137,78 \\
\hline Combate à Formiga $(8 \mathrm{x})$ & Homem-dia & 18,86 & 0.80 & 15,09 \\
\hline Limpeza pomar/Podas & Homem-dia & 18,86 & 1,35 & 25,46 \\
\hline B3. Colheita & & & & 0 \\
\hline Colheita & Empreita (cx 40,8 kg) & 0,70 & 451,6 & 316,12 \\
\hline Subtotal $B$ & & & & 512,34 \\
\hline \multicolumn{5}{|l|}{$\begin{array}{l}\text { C-INSUMOS (CIF) } \\
\text { C1. Fertilizantes }(*)\end{array}$} \\
\hline Calcário & $\mathrm{R} \$ /$ ton & 25,66 & 1,00 & 25,66 \\
\hline Superfosfato Simples & $\mathrm{R} \$ /$ ton & 196,04 & 0.25 & 49,01 \\
\hline NPK $20-00-20$ & $\mathrm{R} \$ /$ ton & 280,20 & 0,30 & 84,06 \\
\hline Uréia & $\mathrm{R} \$ /$ ton & 341,38 & 0,02 & 6,83 \\
\hline Sulfato de Zinco & $\mathrm{R} \$ / \mathrm{Kg}$ & 2,00 & 9,00 & 18,00 \\
\hline Sulfato de Manganês & $\mathrm{R} \$ / \mathrm{Kg}$ & 1,90 & 6,00 & 11,4 \\
\hline Ácido Bórico & $\mathrm{R} \$ / \mathrm{Kg}$ & 2,78 & 3,00 & 8,34 \\
\hline C2. Fitossanitário & $\mathrm{R} \$ / \mathrm{Kg}$ & & & \\
\hline Acaricida & R\$/litro & 39,28 & 4,20 & 164,98 \\
\hline Fungicida & $\mathrm{R} \$ \mathrm{~kg}$ & 17,92 & 3,00 & 53,76 \\
\hline Formicida & $\mathrm{RS} / \mathrm{kg}$ & 8,10 & 0,50 & 4,05 \\
\hline \multicolumn{5}{|l|}{ C3. Herbicidas } \\
\hline Pós Emergente & R\$/litro & 11,26 & 4,20 & 47,29 \\
\hline Subtotal C & & & & 425,68 \\
\hline \multicolumn{5}{|l|}{ D-ADMINISTRAÇATO } \\
\hline Assitência Técnica & $\%$ Subtotal $(A+B+C)$ & $4,00 \%$ & 1,00 & 66,19 \\
\hline Contabil / Escritório + Comerc. & $\%$ Subtotal $(\mathrm{A}+\mathrm{B}+\mathrm{C})$ & $12,0 \%$ & 1,00 & 203,21 \\
\hline Consev./Deprec. Benf. & $\%$ Subtotal $(A+B+C)$ & $3,00 \%$ & 1,00 & 66,22 \\
\hline Subtotal D & & & & 326,91 \\
\hline Custo Total (RS/ha/ano) & & & & $1,751,36$ \\
\hline Receita (RS/ha/ano) & & & & $2.401,92$ \\
\hline Receita líquida por hectare & & & & 650,56 \\
\hline
\end{tabular}


Tabela A13: Custos de produção por hectare, na propriedade $\mathrm{D}$, em $\mathrm{R} \$$, referente a safra 99/00, valores corrigidos em R $\$$ - janeiro/2001.

\begin{tabular}{|c|c|c|c|c|}
\hline \multirow{2}{*}{$\begin{array}{c}\text { DESCRIÇ̃̃̃O } \\
A-O P E R A C ̧ \tilde{O} E S M E C A N I Z .\end{array}$} & \multirow[t]{2}{*}{ ESPECIFICAÇÃO } & \multicolumn{3}{|c|}{$1999 / 00$} \\
\hline & & V.U. & Qtde. & TOTAL \\
\hline \multicolumn{5}{|l|}{ A1. Preparo do Solo } \\
\hline Calagem & HM Tp 70cv. $4 \times 2$ + distr. Calcário $2,3 \mathrm{~m}^{3}$ & 16,56 & 0,92 & 15,23 \\
\hline \multicolumn{5}{|l|}{ A2. Tratos Culturais } \\
\hline Pulverização (4x) & HM Tp $70 \mathrm{cv} .4 \times 2+$ atomizador 20001 & 17,88 & 7,75 & 138,57 \\
\hline Roçagem $(4 \mathrm{x})$ & HM Tp $70 \mathrm{cv} .4 \times 2+$ roçad. Hidraúlica & 15,68 & 9,60 & 150,53 \\
\hline Aplic. de Herbicida ( $1 \mathrm{x})$ & HM Tp 70 cv $4 \times 2+$ pulv. Barras & 16,06 & 1,82 & 29,23 \\
\hline Adubação (4x) & HM Tp $70 \mathrm{cv} .4 \times 2+$ adubadora & 18,44 & 8,45 & 155,82 \\
\hline \multicolumn{5}{|l|}{ A3. Colheita } \\
\hline Colheita & HM Tp 70 cv. $4 \times 2+$ carreta & 0 & 0 & 0 \\
\hline $\begin{array}{l}\text { Subtotal } A \\
B \text { - OPERAÇOES MANUAIS }\end{array}$ & & & & 489,38 \\
\hline \multicolumn{5}{|l|}{ B1. Preparo do solo } \\
\hline Calagem & Homem-dia & 16,30 & 0,40 & 6,52 \\
\hline \multicolumn{5}{|l|}{ B2. Tratos Culturais } \\
\hline Adubação $(4 \mathrm{x})$ & Homem-dia & 16,30 & 0,60 & 9,78 \\
\hline Poda de Limpeza & Homem-dia & 16,30 & 2,00 & 32,60 \\
\hline Combate à Formiga $(2 \mathrm{x})$ & Homem-dia & 16,30 & 4,00 & 65,20 \\
\hline Limpeza pomar /Podas & Homem-dia & 16,30 & 5,00 & 81,50 \\
\hline \multicolumn{5}{|l|}{ B3. Colheita } \\
\hline Colheita & Empreita (cx 40,8 kg) & 0 & 0 & 0 \\
\hline Subtotal B & & & & 195,60 \\
\hline \multicolumn{5}{|l|}{ C - INSUMOS } \\
\hline \multicolumn{5}{|l|}{ C1. Fertilizantes $\left({ }^{*}\right)$} \\
\hline Calcário & $\mathrm{R} \$ /$ ton & 29,87 & 1,21 & 36,14 \\
\hline Superfosfato Simples & $\mathrm{R} \$$ /ton & 219,00 & 0,39 & 85,41 \\
\hline NPK $20-00-20$ & & 343,00 & 0,45 & 154,35 \\
\hline C2. Fitossanitário & $\mathrm{R} \$ / \mathrm{Kg}$ & & & \\
\hline Acaricida & R\$/litro & 18,54 & 2,00 & 37,08 \\
\hline Formicida & $\mathrm{R} \$ / \mathrm{kg}$ & 10,34 & 3,50 & 36,19 \\
\hline \multicolumn{5}{|l|}{ C3. Herbicidas } \\
\hline Pós Emergente & R\$/litro & 12,55 & 3,5 & 43,92 \\
\hline $\begin{array}{l}\text { Subtotal C } \\
D-A D M I N I S T R A C A O A\end{array}$ & & & & 393,09 \\
\hline Contabil/ / Escritório & $\%$ Subtotal $(A+B+C)$ & $2,00 \%$ & 1,00 & 21,56 \\
\hline M.O Administrativa & $\%$ Subtotal $(A+B+C)$ & $2,00 \%$ & 1,00 & 21,56 \\
\hline Subtotal D & & & & 43,12 \\
\hline \multicolumn{3}{|l|}{ Custo Total (R\$/ha/ano) } & & $1.121,19$ \\
\hline \multicolumn{3}{|l|}{ Receita (R\$/ha/ano) } & & $1.633,50$ \\
\hline \multicolumn{3}{|l|}{ Receita líguida por hectare } & & 512,31 \\
\hline
\end{tabular}


Tabela A14: Custos de produção por hectare, na propriedade $\mathrm{E}$, em R\$, referentes a safra 97/98, valores corrigidos em R\$ - Janeiro/2001 .

\begin{tabular}{|c|c|c|c|c|}
\hline DESCRIÇÃO & ESPECIFICAÇÃO & \multicolumn{3}{|c|}{$1997 / 98$} \\
\hline A-OPERACÕES MECANIZ. & & V.U. & Qtde. & TOTAL \\
\hline \multicolumn{5}{|l|}{ A1. Preparo do Solo } \\
\hline \multicolumn{5}{|l|}{ A2. Tratos Culturais } \\
\hline Pulverização com quelatos (6x) & HM Tp 70cv. $4 \times 2+$ atomizador 20001 & 19,87 & 14,40 & 286,13 \\
\hline Roçagem $(4 \mathrm{x})$ & HM Tp 70 cv. $4 \times 2$ + roçad. Hidraúlica & 15,81 & 6,52 & 103,08 \\
\hline Adubação $(4 x)$ & HM Tp $70 \mathrm{cv} .4 \times 2$ + adubadora & 19.45 & 5.50 & 106,97 \\
\hline Pulverização com caldas $(8 \mathrm{x})$ & HM Tp $70 \mathrm{cv} .4 \times 2+$ atomizador 20001 & 17,93 & 16,75 & 300,33 \\
\hline $\begin{array}{c}\text { Pulveriz. c/ } \\
\text { biofertilizante }(12 x)\end{array}$ & HM Tp 70cv. $4 \times 2+$ atomizador 20001 & $0 \ldots$ & 0 & 0 \\
\hline \multicolumn{5}{|l|}{ A3. Colheita } \\
\hline Colheita & HM Tp 70 cv. $4 \times 2+$ carreta & 19.09 & 4,50 & 85,90 \\
\hline Subtotal A & & & & 882,41 \\
\hline \multicolumn{5}{|l|}{ B-OPERAÇÕES MANUAIS } \\
\hline \multicolumn{5}{|l|}{ B1. Preparo do solo } \\
\hline \multicolumn{5}{|l|}{ B2. Tratos Culturais } \\
\hline Adubação (4x) & Homem-dia & 15.40 & 0,40 & 6,16 \\
\hline Poda de Limpeza & Homem-dia & 15,40 & 6,00 & 92,40 \\
\hline Combate à Formiga (4x) & Homem-dia & 15,40 & 1,50 & 23,10 \\
\hline Limpeza pomar/Podas & Homem-dia & 15,40 & 1,20 & 18,48 \\
\hline \multicolumn{5}{|l|}{ B3. Colheita } \\
\hline & Empreita (cx $40.8 \mathrm{~kg})$ & 0.75 & 525,81 & 394,36 \\
\hline Subtotal B & & & & 534,50 \\
\hline \multicolumn{5}{|l|}{ C-INSUMOS } \\
\hline \multicolumn{5}{|l|}{ C1. Fertilizantes $\left({ }^{*}\right)$} \\
\hline Termofosfato & $\mathrm{R} \$$ /ton & 306,02 & 0,60 & 183,61 \\
\hline Cloreto de Potássio & $\mathrm{R} \$$ /ton & 518,44 & 0,30 & 155,53 \\
\hline Nitrocálcio & $\mathrm{R} \$ /$ ton & 326,87 & 0,25 & 81,72 \\
\hline Mistura de quelatos & $\mathrm{R} \$$ /litro & 4,55 & 15,00 & 68,25 \\
\hline \multicolumn{5}{|l|}{ C2. Fitossanitário } \\
\hline Formicida & $\mathrm{R} \$ / \mathrm{kg}$ & 9.60 & 1,20 & 11,52 \\
\hline Mistura de fungos & R\$/litro & 0 & 0 & 0 \\
\hline Calda Sufocálcica & R\$/litro & 3,56 & 32,50 & 115,70 \\
\hline Calda Bordalesa & $\mathrm{R} \$$ /litro & 2,55 & 15,60 & 39,78 \\
\hline $\begin{array}{l}\text { Subtotal C } \\
D-A D M I N I S T R A C \tilde{A} O\end{array}$ & & & & 656,11 \\
\hline \begin{tabular}{|l} 
Viagens \\
\end{tabular} & $\%$ Subtotal $(A+B+C)$ & $1,00 \%$ & 1,00 & 20,73 \\
\hline Assitência Técnica & \% Subtotal $(A+B+C)$ & $2,00 \%$ & 1,00 & 41,46 \\
\hline Contabil./Escritório & \% Subtotal $(A+B+C)$ & $2,00 \%$ & 1,00 & 41,46 \\
\hline M.O Administrativa & $\%$ Subtotal $(A+B+C)$ & $2,50 \%$ & 1,00 & 51,83 \\
\hline Consev./Deprec. Benf. & \% Subtotal $(A+B+C)$ & $1,00 \%$ & 1,00 & 20,73 \\
\hline Impostos/Taxas & $\%$ Receita & $3,00 \%$ & 1,00 & 62,19 \\
\hline Comercialização & $\%$ Receita & $5,00 \%$ & 1,00 & 103,65 \\
\hline Subtotal D & & & & 342,05 \\
\hline \multicolumn{4}{|l|}{ Custo Total (RS/ha/ano) } & $2.415,07$ \\
\hline \multicolumn{4}{|l|}{ Receita (R\$/ha/ano) } & $4.036,21$ \\
\hline \multicolumn{4}{|l|}{ Receita líquida por hectare } & $1.621,14$ \\
\hline
\end{tabular}


Tabela A15: Custos de produção por hectare, na propriedade $E$, em $R \$$, referentes a safra 98/99, valores corrigidos em RS - janeiro/2001.

\begin{tabular}{|c|c|c|c|c|}
\hline DESCRIÇÃO & ESPECIFICACX̃̃O & \multicolumn{3}{|c|}{ 1998/99 } \\
\hline A- OPERAÇÕESMECANIZ. & & V.U. & Qtde. & TOTAL \\
\hline \multicolumn{5}{|l|}{ A1. Preparo do Solo } \\
\hline \multicolumn{5}{|l|}{ A2. Tratos Culturais } \\
\hline Pulverização com quelatos (6x) & HM Tp 70 cv. $4 \times 2+$ atomizador 20001 & 18,06 & 14,40 & 260,06 \\
\hline Roçagem $(4 x)$ & HM Tp $70 \mathrm{cv} .4 \times 2+$ roçad. Hidraúlica & 15,37 & 6,52 & 100,21 \\
\hline Adubação (4x) & HM Tp 70 cv $4 \times 2+$ adubadora & 18,12 & 5,50 & 99,66 \\
\hline Pulverização com caldas (8x) & HM Tp $70 \mathrm{cv} .4 \times 2+$ atomizador 20001 & 16,88 & 16,75 & 282,74 \\
\hline \multicolumn{5}{|l|}{ A3. Colheita } \\
\hline Colheita & HM Tp 70cv $4 \times 2+$ carreta & 17,48 & 4,50 & 78,66 \\
\hline Subtotal $A$ & & & & 821,33 \\
\hline \multicolumn{5}{|l|}{ B-OPERACOOES MANUAIS } \\
\hline \multicolumn{5}{|l|}{ B1. Preparo do solo } \\
\hline \multicolumn{5}{|l|}{ B2. Tratos Culturais } \\
\hline Adubação $(4 \mathrm{x})$ & Homem-dia & 14,20 & 0,40 & 5,68 \\
\hline Poda de Limpeza & Homem-dia & 14,20 & 6,00 & 85.20 \\
\hline Combate à Formiga $(4 x)$ & Homem-dia & 14,20 & 1,50 & 21,30 \\
\hline Limpeza pomar /Podas & Homem-dia & 14,20 & 1,20 & 17,04 \\
\hline \multicolumn{5}{|l|}{ B3. Colheita } \\
\hline & Empreita (cx 40,8 kg) & 0,65 & 578,39 & 375,95 \\
\hline Subtotal B & & & & 505,17 \\
\hline \multicolumn{5}{|l|}{ C-INSUMOS } \\
\hline \multicolumn{5}{|l|}{ C1. Fertilizantes (*) } \\
\hline Termofosfato & $\mathrm{R} \$ /$ ton & 272,32 & 0,60 & 163,39 \\
\hline Cloreto de Potássio & $\mathrm{RS/ton}$ & 473,11 & 0,30 & 141,93 \\
\hline Nitrocálcio & $\mathrm{R} \$$ /ton & 0 & 0 & 0 \\
\hline Mistura de quelatos & $\mathrm{R} \$$ /litro & 4,21 & 16,00 & 67,36 \\
\hline \multicolumn{5}{|l|}{ C2. Fitossanitário } \\
\hline Formicida & $\mathrm{R} \$ / \mathrm{kg}$ & 9,44 & 1,00 & 9,44 \\
\hline Mistura de fungos & R\$/litro & 0 & 0 & 0 \\
\hline Calda Sufocálcica & R\$/litro & 3,22 & 28,30 & 91,13 \\
\hline Calda Bordalesa & R\$/litro & 2,46 & 17,60 & 43,30 \\
\hline $\begin{array}{l}\text { Subtotal C } \\
D-A D M A N I S T R A C A O\end{array}$ & & & & 516,55 \\
\hline Viagens & $\%$ Subtotal $(\mathrm{A}+\mathrm{B}+\mathrm{C})$ & $0,50 \%$ & 1,00 & 9,21 \\
\hline Assitência Técnica & $\%$ Subtotal $(A+B+C)$ & $2,50 \%$ & 1,00 & 46,07 \\
\hline Contabil./ Escritório & $\%$ Subtotal $(A+B+C)$ & $1,50 \%$ & 1,00 & 27,64 \\
\hline M.O Administrativa & $\%$ Subtotal $(A+B+C)$ & $2,00 \%$ & 1,00 & 36,86 \\
\hline Consev./Deprec. Benf. & $\%$ Subtotal $(\mathrm{A}+\mathrm{B}+\mathrm{C})$ & $1,00 \%$ & 1,00 & 18,43 \\
\hline Impostos/ Taxas & $\%$ Receita & $3,00 \%$ & 1,00 & 55,29 \\
\hline Comercialização & $\%$ Receita & $6,50 \%$ & 1,00 & 119,80 \\
\hline Subtotal D & & & & 313,30 \\
\hline \multicolumn{3}{|l|}{ Custo Total (RS/ha/ano) } & & $2,156,35$ \\
\hline \multicolumn{3}{|l|}{ Receita (R\$/ha/ano) } & & $3.086,85$ \\
\hline \multicolumn{3}{|l|}{ Receita liquida por hectare } & & 930,50 \\
\hline
\end{tabular}


Tabela A16: Custos de produção por hectare, na propriedade E, em R\$, referentes a safra 99/00, valores corrigidos em R\$ - janeiro/2001 .

\begin{tabular}{|c|c|c|c|c|}
\hline & ESPECIFICAÇ̃̃O & \multicolumn{3}{|c|}{$1999 / 00$} \\
\hline A- OPERACÕESMECANIZ. & & V.U. & Qtde. & TOTAL \\
\hline \multicolumn{5}{|l|}{ A1. Preparo do Solo } \\
\hline \multicolumn{5}{|l|}{ A2. Tratos Culturais } \\
\hline Roçagem $(4 \mathrm{x})$ & HM Tp 70cv. $4 \times 2+$ roçad. Hidraúlica & 15,77 & 6,52 & 102,82 \\
\hline Adubação (4x) & HM Tp $70 \mathrm{cv} 4 \times 2+$ adubadora & 19,15 & 5,50 & 105,32 \\
\hline Pulverização com caldas $(8 \mathrm{x})$ & HM Tp $70 \mathrm{cv} .4 \times 2+$ atomizador 20001 & 17,18 & 16,75 & 287,76 \\
\hline $\begin{array}{c}\text { Pulveriz. } \mathrm{c} / \\
\text { biofertilizante }(12 \mathrm{x})\end{array}$ & HM Tp $70 \mathrm{cv} .4 \times 2+$ atomizador 20001 & 18,14 & 21,30 & 386,38 \\
\hline \multicolumn{5}{|l|}{ A3. Colheita } \\
\hline Colheita & HM Tp $70 \mathrm{cv} .4 \times 2+$ carreta & 17,93 & 4,50 & 80,68 \\
\hline $\begin{array}{l}\text { Subtotal } A \\
B \text {-OPERAÇOES MANUAIS }\end{array}$ & & & & 962,96 \\
\hline \multicolumn{5}{|l|}{ B1. Preparo do solo } \\
\hline \multicolumn{5}{|l|}{ B2. Tratos Culturais } \\
\hline Adubação $(4 \mathrm{x})$ & Homem-dia & 15,00 & 0,40 & 6,00 \\
\hline Poda de Limpeza & Homem-dia & 15,00 & 6,00 & 90,00 \\
\hline Combate à Formiga $(4 \mathrm{x})$ & Homem-dia & 15,00 & 1,50 & 22,50 \\
\hline Limpeza pomar/Podas & Homem-dia & 15,00 & 1,20 & 18,00 \\
\hline \multicolumn{5}{|l|}{ B3. Colheita } \\
\hline & Empreita (cx 40,8 kg) & 0,80 & $1.026,88$ & 821,50 \\
\hline Subtotal B & & & & 958,00 \\
\hline \multicolumn{5}{|l|}{ C-INSUMOS } \\
\hline \multicolumn{5}{|l|}{ C1. Fertilizantes $(*)$} \\
\hline Termofosfato & $\mathrm{R} \$ /$ ton & 264,99 & 0,60 & 158,99 \\
\hline Cloreto de Potássio & $\mathrm{R} \$ /$ ton & 0 & 0 & 0 \\
\hline Nitrocálcio & $\mathrm{R} \$$ /ton & 0 & 0 & 0 \\
\hline Mistura de quelatos & R\$/litro & 0 & 0 & 0 \\
\hline Biofertilizante & R\$/litro & 3,85 & 31,20 & 120,12 \\
\hline Torta de Mamona & $\mathrm{R} \$ /$ ton & 185,00 & 3,20 & 592,00 \\
\hline \multicolumn{5}{|l|}{ C2. Fitossanitário } \\
\hline Mistura de fungos & $\mathrm{R} \$ /$ litro & 4,80 & 0,50 & 2,40 \\
\hline Calda Sufocálcica & R\$/litro & 3,12 & 45,50 & 141,96 \\
\hline Calda Bordalesa & R\$/litro & 2,13 & 36,20 & 77,11 \\
\hline Subtotal C & & & & $1.092,58$ \\
\hline \multicolumn{5}{|l|}{ D-ADMINISTRAC CAO } \\
\hline Viagens & $\%$ Subtotal $(A+B+C)$ & $0,50 \%$ & 1,00 & 15,07 \\
\hline Assitência Técnica & $\%$ Subtotal $(\mathrm{A}+\mathrm{B}+\mathrm{C})$ & $3,00 \%$ & 1,00 & 90,41 \\
\hline Contabil./Escritório & $\%$ Subtotal $(A+B+C)$ & $1,00 \%$ & 1,00 & 30,14 \\
\hline M.O Administrativa & $\%$ Subtotal $(A+B+C)$ & $1,50 \%$ & 1,00 & 45,20 \\
\hline Consev./Deprec. Benf. & $\%$ Subtotal $(\mathrm{A}+\mathrm{B}+\mathrm{C})$ & $1,00 \%$ & 1,00 & 30,14 \\
\hline Impostos/ Taxas & $\%$ Receita & $3,00 \%$ & 1,00 & 90,41 \\
\hline Comercialização & $\%$ Receita & $7,00 \%$ & 1,00 & 210,95 \\
\hline Subtotal D & & & & 512,32 \\
\hline \multicolumn{3}{|l|}{ Custo Total (RS/ha/ano) } & & $3.525,86$ \\
\hline \multicolumn{3}{|l|}{ Receita (R\$/ha/ano) } & & $5.248,26$ \\
\hline \multicolumn{3}{|l|}{ Receita líquida por hectare } & & $1.722,40$ \\
\hline
\end{tabular}


ANEXO B: Dados referentes as análises de solo

Tabela B1: Análises de Solo - micronutrientes - Propriedade B DATA: 10/09/98

\begin{tabular}{|c|c|c|c|c|c|c|c|}
\hline \multicolumn{2}{|c|}{ AMOSTRAS N. } & B & Cu & Fe & Mn & Zn & S \\
\hline Lab. & Solic. & \multicolumn{5}{c|}{$\mathrm{mg} / \mathrm{dm}^{3}$} & \\
\hline 10411 & POMAR & 0,18 & 1,0 & 87,2 & 6,4 & 0,7 & 15 \\
\hline 10412 & MILHO & 0,33 & 2,4 & 39,8 & 5,2 & 2,7 & 6 \\
\hline & & & & & & & \\
\hline
\end{tabular}

Tabela B2: Análises de Solo - micronutrientes - Propriedade C DATA: 04/09/98

\begin{tabular}{|c|c|c|c|c|c|c|c|}
\hline \multicolumn{2}{|c|}{ AMOSTRAS N. } & B & $\mathrm{Cu}$ & $\mathbf{F e}$ & $\mathbf{M n}$ & $\mathbf{Z n}$ & $\mathbf{S}$ \\
\hline Lab. & Solic. & \multicolumn{6}{|c|}{$\mathrm{mg} / \mathrm{dm}^{3}$} \\
\hline 10374 & HORTA & 0,34 & 0,7 & 44,5 & 1.8 & 2,3 & 36 \\
\hline 10375 & POMAR & 0,27 & 1,1 & 34,6 & 2,9 & 0,8 & 14 \\
\hline 10376 & EUCALIPTO & 0,33 & 0,4 & 77,2 & 1,8 & 0,5 & 17 \\
\hline & & & & & & & \\
\hline
\end{tabular}




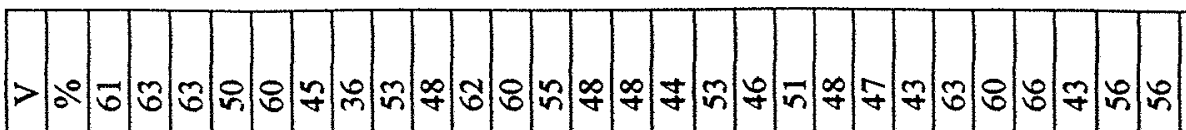

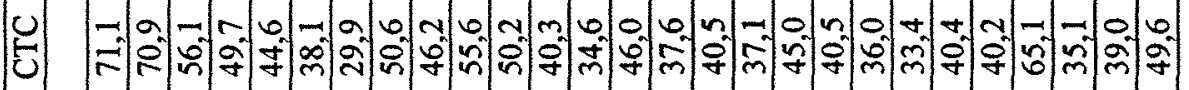

क ने ले

«

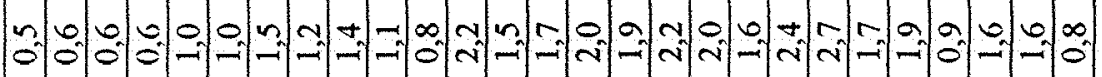

二

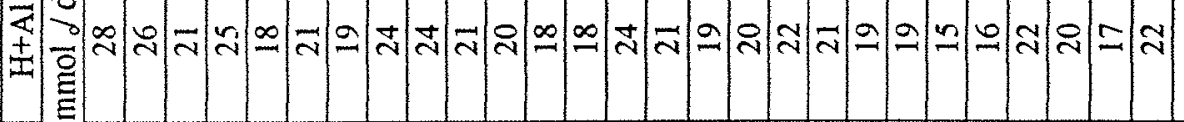

2

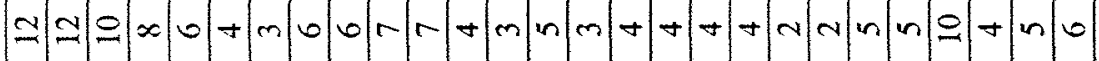

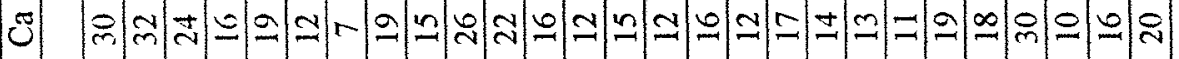

$\frac{2}{2}$

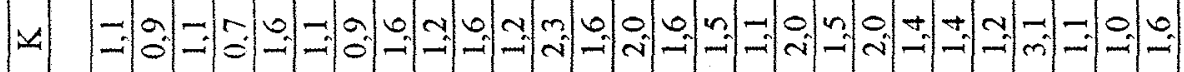

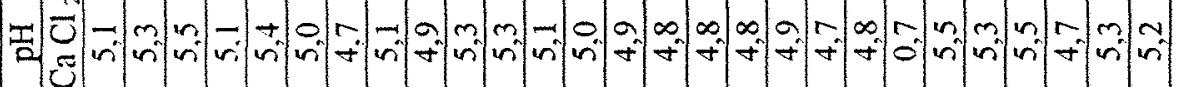

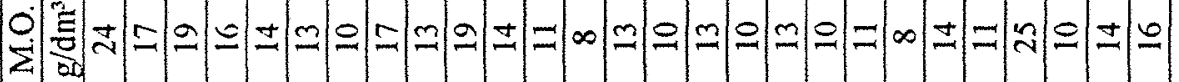

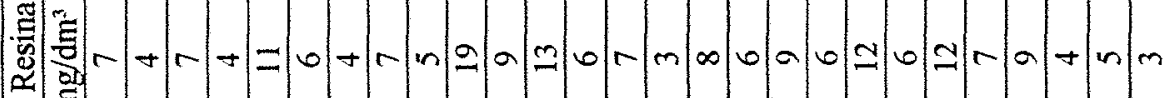
a.

a.

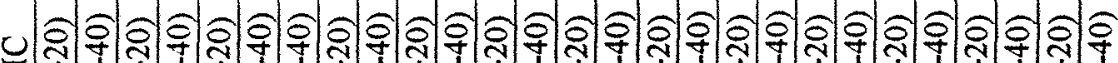

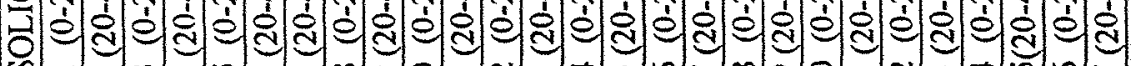

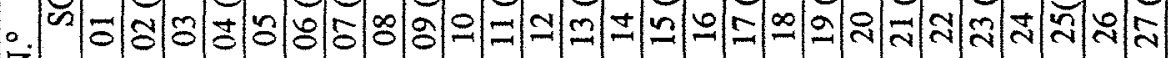

西

$=2$ ㅇำㅇำ 


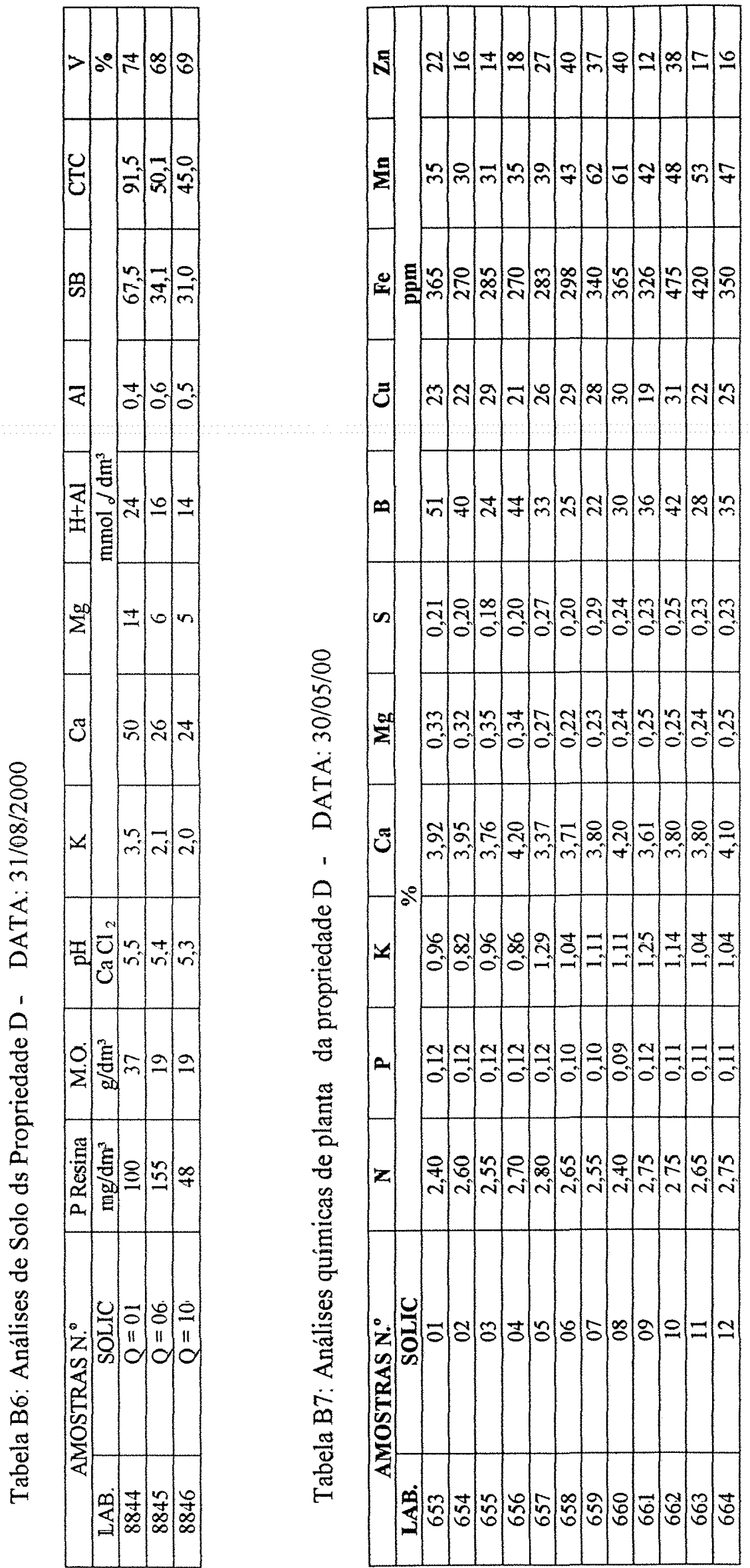




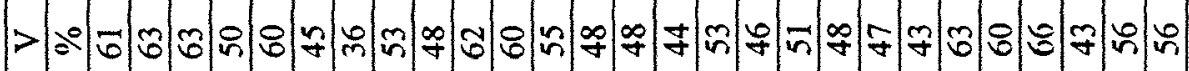

光 हो

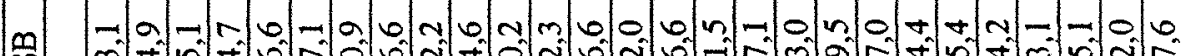

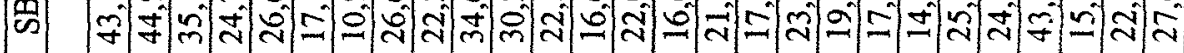

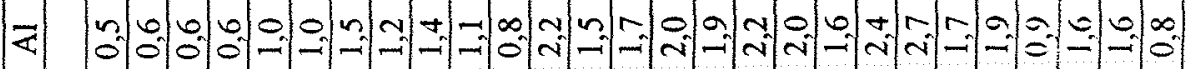

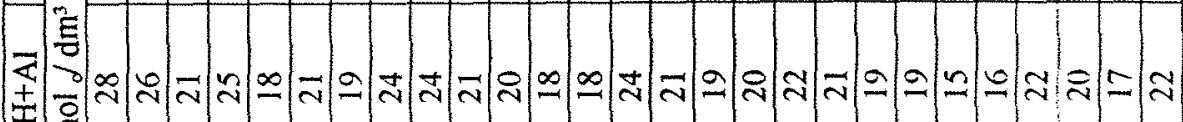

考

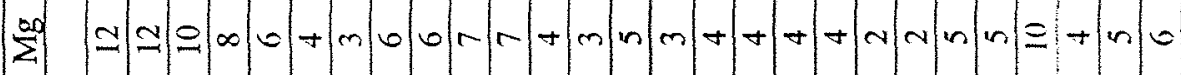

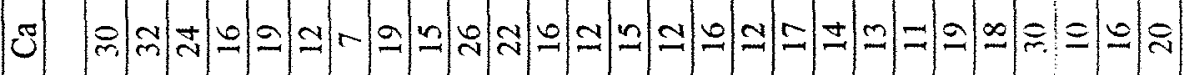

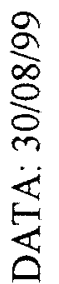

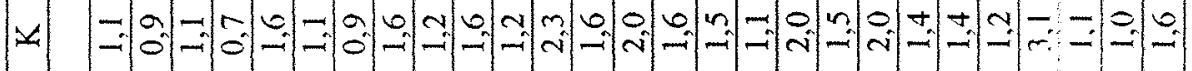

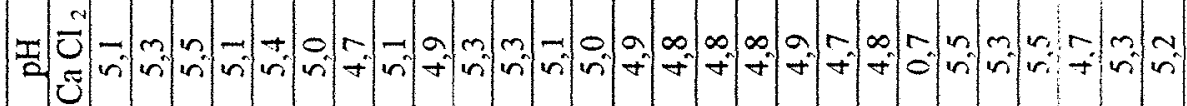

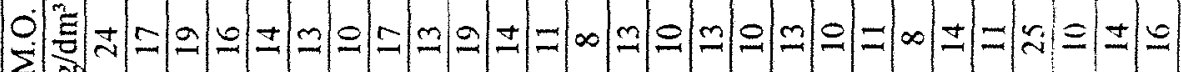

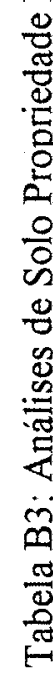

穿

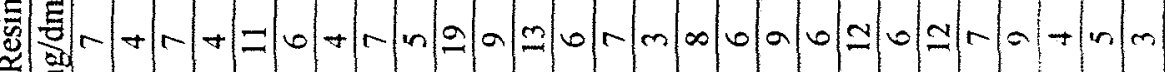

2.

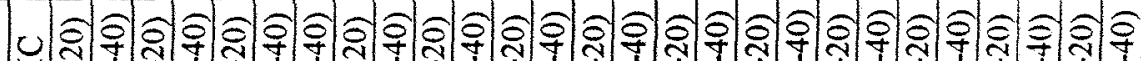

خे

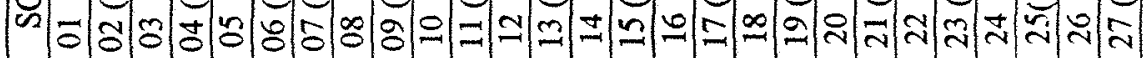

z

z

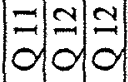

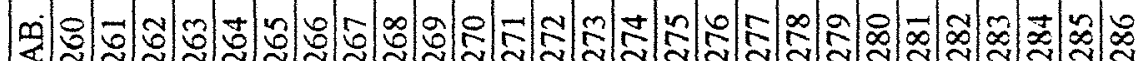

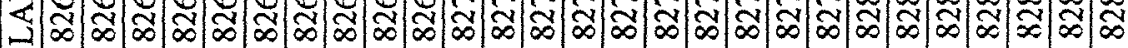


ANEXO C: Dados referentes as análises de água

Tabela C1: Análises da água de irrigação, realizadas em agosto/2000, nas propriedades $\mathrm{B}$ e C

\begin{tabular}{|c|c|c|c|c|c|c|c|c|c|c|}
\hline & \multicolumn{10}{|c|}{$m g ~^{-1}$} \\
\hline CÓDIGO & $\mathrm{Ca}$ & Mg & SO & $\mathbf{P}$ & $\mathbf{K}$ & $\mathrm{Na}$ & Si & $\mathrm{Cu}$ & $\mathbf{Z n}$ & Mn \\
\hline PROPR. B & 0,76 & 0,21 & $<1,50$ & $<0,20$ & $<0,30$ & 1,01 & 3,01 & $<0,005$ & $<0,06$ & 0,007 \\
\hline PROPR. C & 0,61 & 0,25 & $<1,50$ & $<0,20$ & $<0,30$ & 1,15 & 2,74 & $<0,005$ & $<0,06$ & 0,005 \\
\hline
\end{tabular}

\begin{tabular}{|c|c|c|c|c|c|c|c|c|c|c|}
\hline & \multicolumn{10}{|c|}{$\mathrm{mg} \mathrm{I}^{-1}$} \\
\hline CÓDIGO & B & Fe & Al & $\mathrm{Sr}$ & $\mathbf{B a}$ & $\mathbf{P b}$ & Cd & $\mathrm{Cr}$ & Mo & $\mathrm{Ni}$ \\
\hline PROPR. B & $<0,03$ & 0,3 & 0,1 & 0,004 & 0,008 & $<0,20$ & $<0,04$ & $<0,02$ & $<0,03$ & $<0,05$ \\
\hline PROPR C C & $<0,03$ & 0,22 & $<0,10$ & 0,004 & 0,007 & $<0,20$ & $<0,04$ & $<0,02$ & $<0,03$ & $<0,05$ \\
\hline
\end{tabular}

Fonte: DAAE de Rio Claro 
ANEXO D: Dados Referentes à Produtividade

Tabela D1: Produção das variedades de citros da propriedade D

\begin{tabular}{|l|c|c|c|c|c|c|c|}
\hline & & \multicolumn{2}{|c|}{$\begin{array}{c}\text { PLANTIO- } \\
\text { MÉDIA }\end{array}$} & \multicolumn{4}{|c|}{ Produção, em caixas de 40,8kg } \\
\hline & N $^{\circ}$ PES & MÊSS & MÊS & $\mathbf{9 6 / 9 7}$ & $\mathbf{9 7 / 9 8}$ & $\mathbf{9 8 / 9 9}$ & $\mathbf{9 9 / 0 0}$ \\
\hline & & & & & & & \\
\hline Hamlin & 2.250 & $06 / 95$ & & 0,0 & 0,0 & 697,7 & $5.309,4$ \\
\hline Pera (A) & 3.000 & $07 / 92$ & & $3.360,0$ & $3.990,0$ & - & - \\
\hline Pera A + B + C & 10.250 & $07 / 93$ & $05 / 94$ & - & - & $10.536,7$ & $16.912,5$ \\
\hline Valência (A) & 6.790 & $11 / 90$ & & $10.943,2$ & $22.092,0$ & - & - \\
\hline Valência (B) & 7.500 & $04 / 93$ & & - & $6.525,0$ & - & - \\
\hline Valência A + B & 14.290 & & & - & - & $23.282,6$ & - \\
\hline Valência A + B + C & 17.040 & $05 / 94$ & - & - & - & - & $31.718,0$ \\
\hline Total / Média* & $\mathbf{2 9 . 5 4 0}$ & $\mathbf{0 7 / 9 2}$ & & $\mathbf{1 4 . 3 0 3 , 2}$ & $\mathbf{3 2 . 6 0 7 , 0}$ & $\mathbf{3 4 . 5 1 7 , 0}$ & $\mathbf{5 3 . 9 2 2 , 7}$ \\
\hline
\end{tabular}

Tabela D2: Produção de diversas variedades de citros da propriedade E.

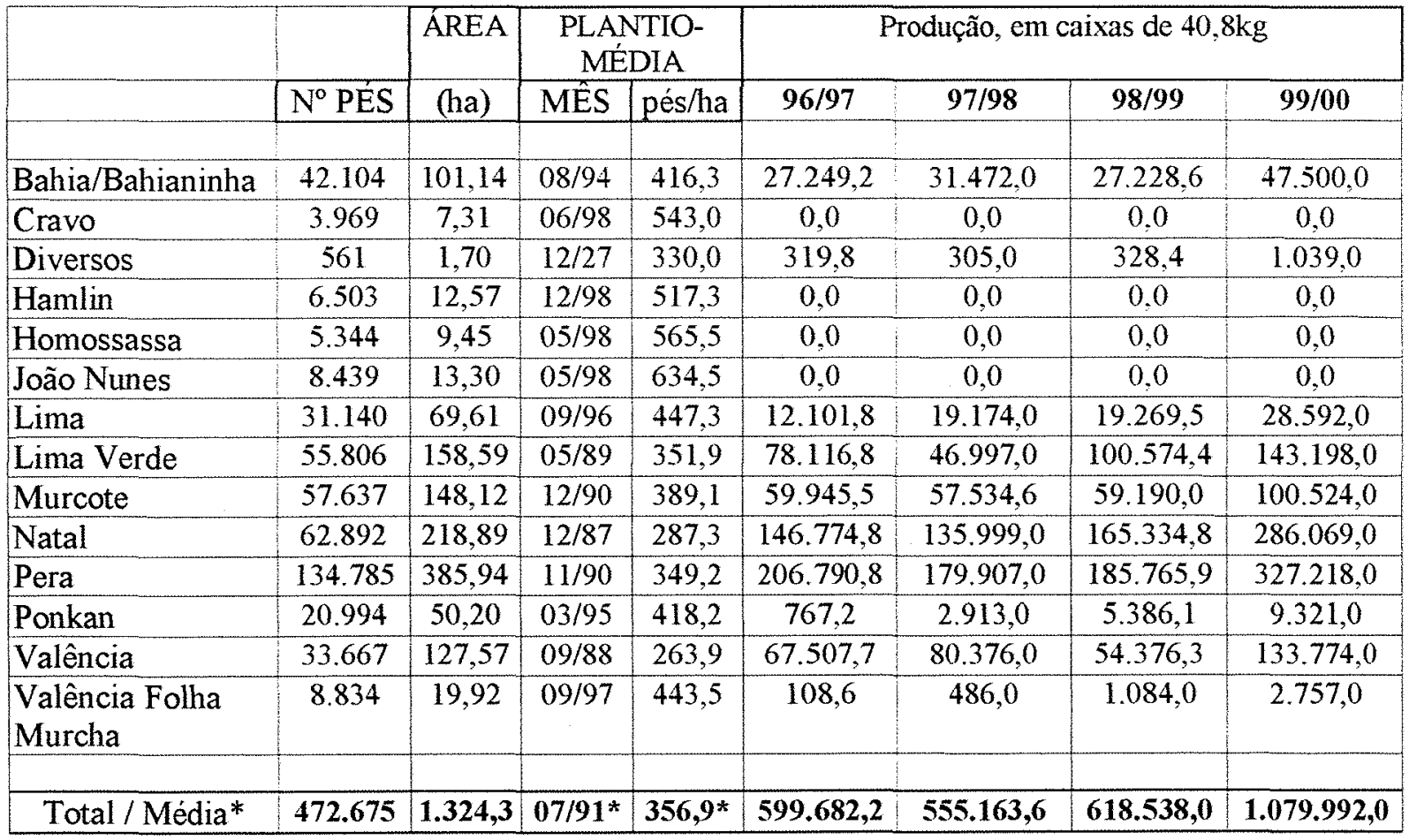




\section{ANEXO E: Dados Referentes a Climatologia}

Tabela E1 - Boletim Pluviométrico CEAPLA-IGCE-UNESP.

Ano:1998 Latitude: $22^{\circ} 23^{\prime} \mathrm{S}$ Longitude: $47^{\circ} 32^{\prime} \mathrm{W}$ Altitude: $626,5 \mathrm{~m}$

Alturas Diárias de Chuva (mm*)

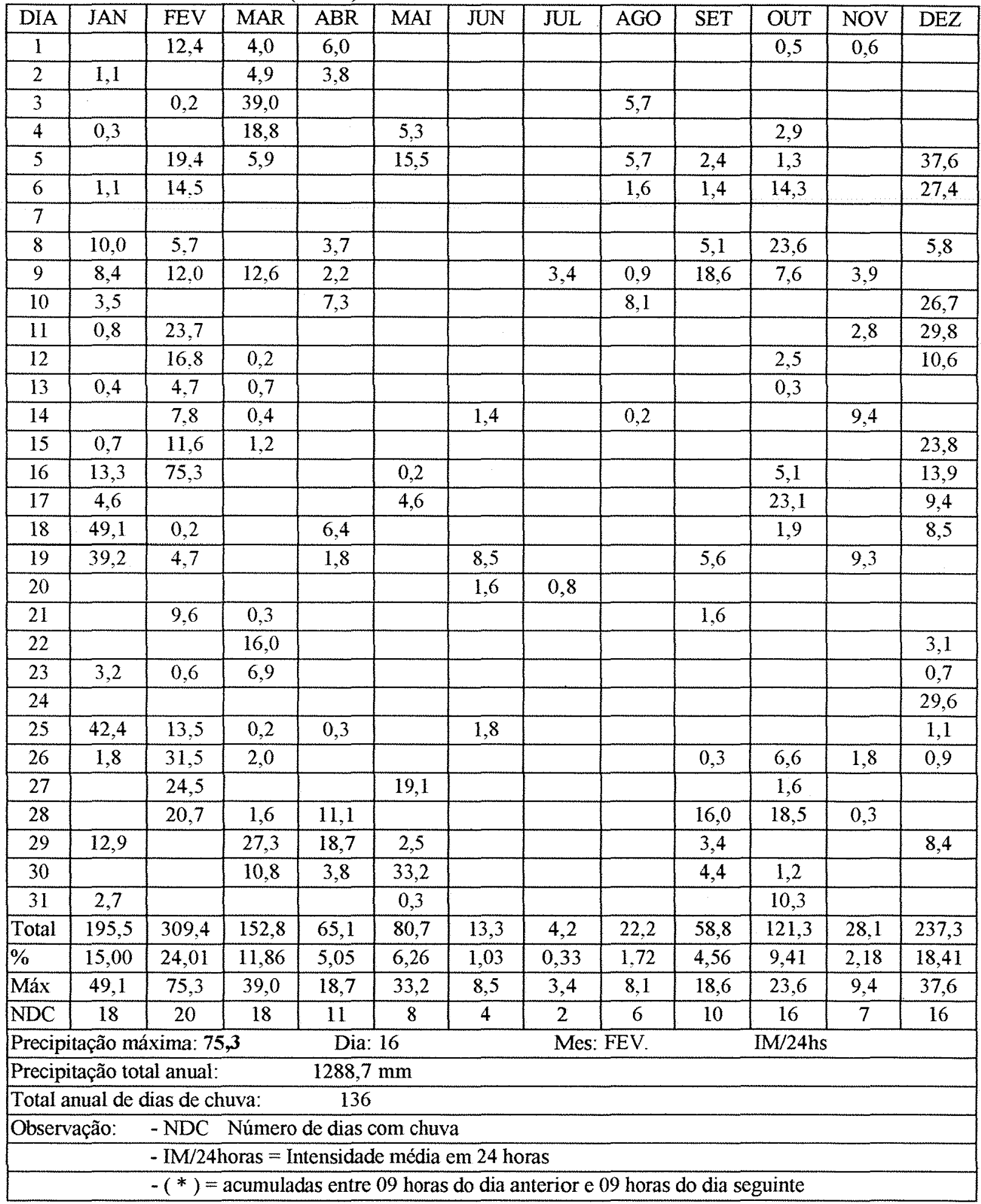


Tabela E2 - Boletim Pluviométrico CEAPLA-IGCE-UNESP.

Ano:1999 Latitude: $22^{\circ} 23^{\prime} \mathrm{S}$ Longitude: $47^{\circ} 32^{\prime} \mathrm{W}$ Altitude: $626,5 \mathrm{~m}$

Alturas Diárias de Chuva (mm*)

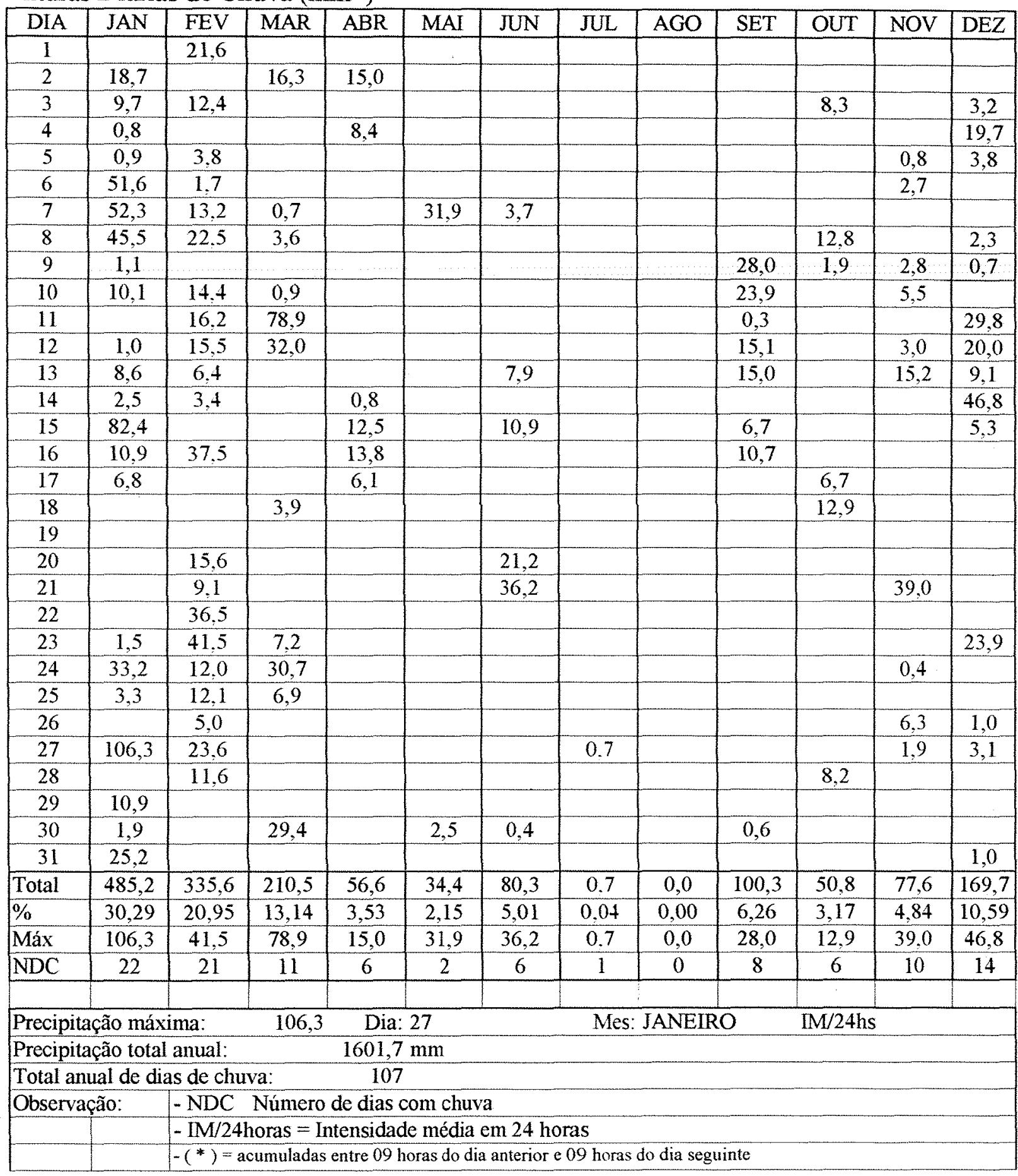


Tabela E3 - Boletim Pluviométrico CEAPLA-IGCE-UNESP 2000

Latitude: $22^{\circ} 23^{\prime} \mathrm{S} \quad$ Longitude: $47^{\circ} 32^{\prime} \mathrm{W}$ Altitude: $626,5 \mathrm{~m}$

Alturas Diárias de Chuva (mm*)

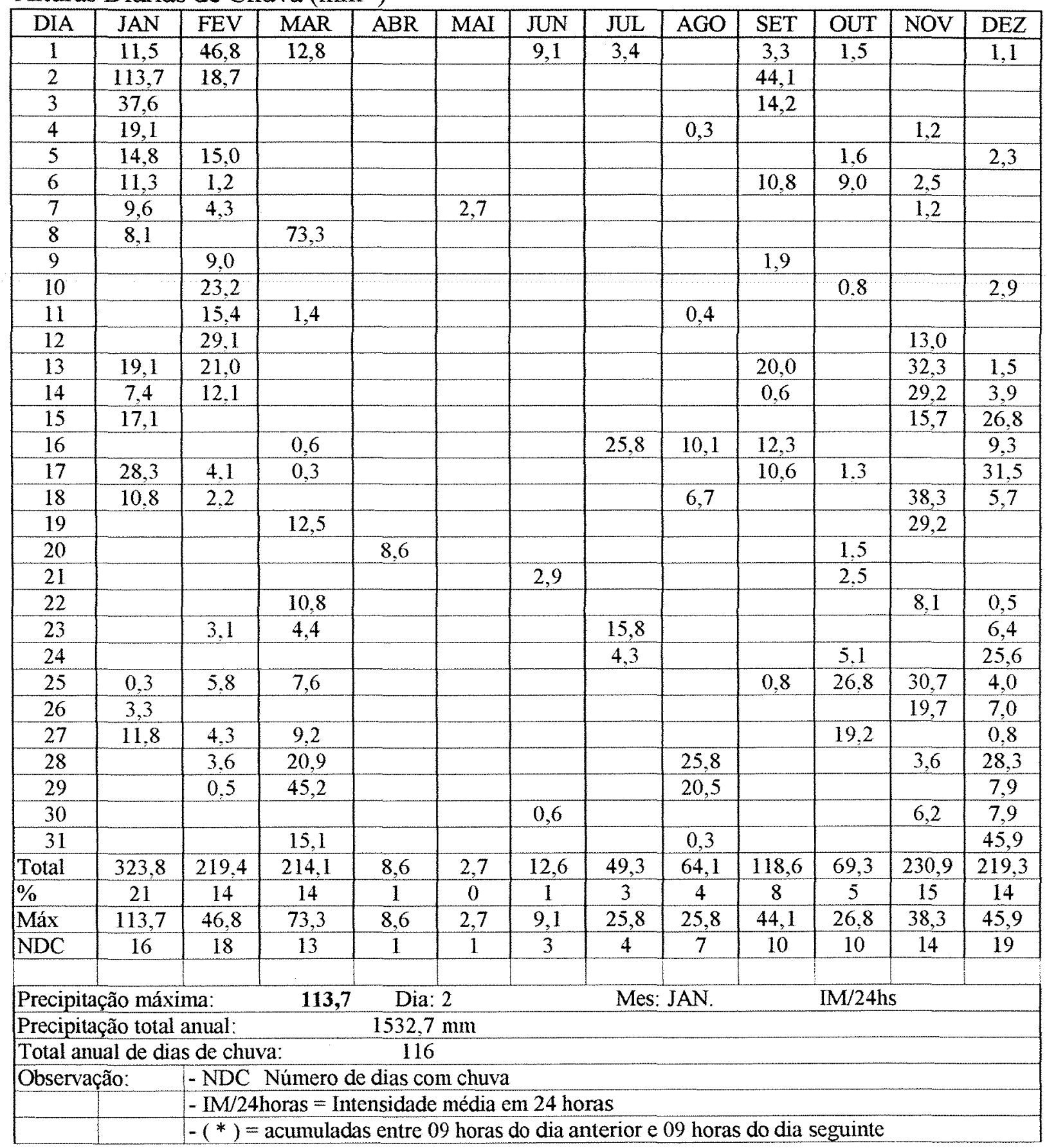




\section{REFERÊNCIAS BIBLIOGRÁFICAS}

ALMEIDA, J. Da ideologia do progresso à idéia de desenvolvimento (rural) sustentável. In: Almeida, J.; Navarro, $Z$ (org.). Reconstruindo a agricultura. Idéias e ideais na perspectiva do desenvolvimento rural sustentável. Porto Alegre, Ed. Universidade/UFRGS, 1998. p.33-55.

ALTIERI, M.A. Agroecology: The scientific basis of alternative agriculture. Boulder, Westview Press. 1987. 227p.

ALTIERI, M.A. Agroecologia, as bases científicas da agricultura alternativa. Rio de Janeiro: PTA/FASE, 1989. 237p.

ALTIERI, M.A. Sustainable agricultural development in Latin America: exploring the possibilities. Agriculture, Ecosystems and Environment, 39, p. 1-21,1992.

BERTAlanffy, L. von. Teoria geral dos sistemas. 2.ed. Petrópolis, Vozes, 1975. $351 \mathrm{p}$.

BILLAUD, J.P. Agricultura sustentável nos países desenvolvidos: conceito aceito e incerto. Agricultura Sustentável, v.2, n², jul./dez., p.2333,1995.

BONANNO, A.; MARSDEN, T.; SILVA, J.G. Globalização e localização: elementos para entender a reestruturação dos espaços rurais. In: CAVALCANTI, J.S.B. (org) Globalização, trabalho, meio ambiente. Recife, Universitária/UFPE, 1999, p. 341366.

BONNEVIALE, J.R. et alii. Approche globale de l'exploitation agricole; compreendere le fonctionnement de l'exploitation agricole: une méthode pour la formation et le developpement. Dirjojon, INRAP, 1989. 350p.

BONILLA, J.A. Fundamentos de agricultura ecológica. São Paulo: Nobel, 1992. 112p.

BROWN, L.R.; YOUNG, J.E. Alimentando o Mundo nos anos 90. In: BROWN, L.R. (org.). Salve o Planeta! Qualidade devida-1990. São Paulo: Globo. p.83-105.

BOURGEOIS, A. Une application de la notion de systéme: L'exploitatior agricole. Agriscope, Angers, 1 (1): p15-31, 1983. 
BUZZANELL, P.J. The U.S. organic sugar market. Sugar y Azucar, v.95, n.9, Sept., 2000.p. 18-30.

CAMPANHOLA, C.; LUIZ, A.J.B.; LUCCHIARI Jr., A. O problema ambiental no Brasil: agricultura. In: ROMEIRO, A.R.; REYDON, B.P.; LEONARDI, M.L.A. (Org.). Economia do meio ambiente: teoria, políticas e a gestão de espaços regionais. Campinas, SP: UNICAMP.IE, 1996. p. 265-281.

CARROL. C.R.; VANDERMEER, J.H.; ROSSET, P.M. Agroecology. New York, McGraw-Hill, 1990. 641p.

CEMBALO, L. Desempenho econômico e comercialização em fazendas orgânicas no sul da Itália. Agricultura em São Paulo . São Paulo, Instituto de Economia Agrícola v. 47, n. 1,2000 . p. $53-63$.

CERVEIRA, R.; CASTRO, M.C. Perfil sócio-econômico dos consumidores de produtos orgânicos da cidade de São Paulo - uma análise empirica. Orgânica, v.1, ed.1, nov., 1999. p. 8-11. (Boletim)

CHABOUSSOU, F. Santé des Cultures: Une révolution agronomique. Paris: Flammarion, La Maison Rustique. 270p.

CHAMBERS, R. Participatory rural appraisals: past, present and future. Forests, Trees and People Newsletter, Rome, FAO, n. 15/16, 1992. p.4-9.

CHARITY, R. Abertura para a produção e distribuição de produtos orgânicos: o exemplo do Ceará. Agricultura Biodinâmica, Ano14, n.79, 1997. p.16-17.

CICIA, G.; DEL GIUDICE, T.; QUARTO, A. L' organizzazione del mercato dei prodotti biologici in Campania: un'analisi di filiera. In: Paper presented at $35^{\circ}$ SIDEA Convey held in Palermo, 1998. www.cds.unina.it/ cicia.

CONWAY, G.R.; BARBIER, E.B. After the green revolution: sustainable agriculture for development. London, Earthscan Publication, 1990. 205p.

COSTA, M.B.B. Subsídio à definição da área de influência/ abrangência de unidade de validação e capacitação tecnológica em agroecologia. CNPMA/EMBRAPA, 1995, 63p. 
DEFFONTAINES, J. P. Systèmes agricoles et paysages. In: Jolivet, M. Pour une agriculture diversifé. Paris, Editions LL'Harmattan, 1988. p.225-32.

DUFUMIER, M. Systèmes de production et developpement agricole dans le tiers-monde. Les Cachiers de la Recherche-Développement, Paris, 6: p31-8. 1985.

DULlEY, R.D. ; SOUZA, M.C. M. de; NOVOA, A. Passado, ações presentes e perspectivas da Associação de Agricultura Orgânica (AAO), São Paulo, Brasil. Informações Econômicas. Instituto de Economia Agrícola, v. 30, n.11, nov. 2000.

DUMAZERT, P. \& LEVARD, L. Los sistemas de production racionalidades economicas. Managua, Instituo Superior de Ciencias Agropecuarias, 1987. 45p.

EHLERS, E. Agricultura Sustentável: Origens e perspectivas de um novo paradigma. São Paulo: Livros da Terra, 1996. 178p.

EHLERS, E. Possíveis veredas da transição à agricultura sustentável. Agricultura Sustentável, v.2, n², jul./dez., p.12-22,1995.

FANCELli, A.L. Sistemas de Produção. Cursos Agrozootécnicos, Piracicaba: SEBRAE-SP, 1994. 197p.

FAO/ONU. Declaração de Den Bosch. 1992.

FARSHAD, A.; ZINCK, J.A. Seeking agricultural sustainability. Agric. Ecosys. Environ., v.47, 1993. p.1-12.

FERRARO JÚNIOR, L. A. Proposta de um método de diagnóstico de sistemas de produção para fins de sustentabilidade - estudo de caso. Piracicaba, ESALQUSP, 1999. 103p. Dissertação de Mestrado.

FIGUEIREDO, J.O. Variedades copa de valor comercial. In: Rodrigues, O. et al. Citricultura Brasileira $2^{2}$ ed. Campinas, Fundação Cargill, 1991.v.1, p.228-264.

FNP CONSUltoria E COMÉRCIO, AgRIANUAL 99, Anuário da Agricultura Brasileira. São Paulo: Editora Argos Comunicação, 1999. p. 250-277.

FRIGHETTO, R.T.S. Impacto ambiental decorrente do uso de pesticidas agrícolas. In: MELO, I.S.; AZEVEDO, J.L.(Ed.). Microbiologia Ambiental. Jaguariúna: EMBRAPA/CNPMA, 1997. p. 415-438. 
GLIESSMANN, S.R. (ed.). Agroecology: Researching the ecological basis for sustainable agriculture. New York: Springer Verlag, 1990. 380p.

GRAZIANO NETO, F. Questão agrária e ecologia: crítica da moderna agricultura. São Paulo, Ed. Brasiliense, 1982. 155p.

HARKALY, A. Perspectivas da agricultura orgânica no mercado internacional. $1^{\circ}$ Encontro Citricultura Sustentável, Limeira, 20-21 maio, 1999. Resumos... p.52-68.

HARKALY, A. Soja orgânica no Brasil. Agricultura Biodinâmica, ano17, n.84, p. 15-16, 2000.

HARKALY, A.; CARMO, M.S.; MAGALHÃES, M.M.; PIMENTA, S. Os contornos econômicos do café orgânico brasileiro. Agricultura Biodinâmica, Ano 14, n.79, 1997. p. 6-14.

HART, R.D. Agroecossistemas - conceptos basicos. Turrialba, Centro Agronomico Tropical de Investigación Y Enseñanza, 1980. 211p.

HOFFMANN, R. et al. Administração de empresa agrícola. Livraria Pioneira, 3 ed., $1981.325 \mathrm{p}$.

IAPAR, Encontro em Sistemas de Produção . Resumos, junho 1993. 22p.

IKERD, J.E. The need for a system approach to sustainable agriculture. Agriculture, Ecosystems and Environment, v.46, 1993. p.147-160.

JESUS, E.L. Relatório sobre o Seminário "Paradigmas da Agroecologia e do Desenvolvimento Sustentado". Mendes, RJ, 20-22 ago., 1993. Relatório..., Rio de Janeiro, AS-PTA, dez., 1993. 40p.

JESUS, E.L. Da agricultura alternativa à agroecologia: para além das disputas conceituais. Agricultura Sustentável, v.3 n.1/2, 1996. p.13-27.

JOUVE, $\mathrm{Ph}$. Quelques principes de construction de typologies d'exploitations agricoles suivant differents sitations agraires. Les Cahiers de la Recherche-Developpement, Montpellieer, 11: p18-32, 1986.

KITAMURA, P.C. A agricultura e o desenvolvimento sustentável. Agricultura Sustentável, v. 1 n.1, 1994. p.27-32.

LANDRIÉRE, J. Systèmes. In: Encyclopaedia Universalis, Paris, 15: 686, 1984. 
LAUX, L.C. Citricultura orgânica no Rio Grande do Sul. $1^{\circ}$ Encontro Citricultura Sustentável, Limeira, 20-21 maio, 1999. Resumos... p.69-70.

LEWANDOWSKI, I; HÄRDTLEIN, M.; KALTSCHMITT, M. Sustainable crop production: definition and methodological approach for assessing and implementing sustainability. Crop Science, v.39, 1999. p.184-193.

LYNAM, J.F; HERDT R.W., Sense ande sustainability: Sustainability as a objective in internatinal agricultural research. Agric. Econ., 3:381-398.)

LOPES, A.S. Solos sob "cerrado": Características, propriedades e manejo. 2 ed. Piracicaba: Associação Brasileira para Pesquisa da Potassa e do Fosfato, 1984. 162p. MAZOYER, M. Rapport de synthèse preliminaire présente au "Comitê Dynamique des systémes agraires". Paris, Ministere de la Cooperation et Ministere de Recherche et de la Technologie, janvier, 1986. 15p.

MELARATO, M. Manejo da fertilidade do solo em culturas perenes sob plantio direto. Plantio Direto, p. 15-23, 1999.

MELO, B. Mercado de orgânicos está em expansão. O Estado de São Paulo, 15/nov., 2000. p10.

MIYAZAWA, M.; PAVAN, M.A.; FRANCHINI, J.C. Neutralização da acidez do perfil do solo por resíduos vegetais. Informações Agronômicas, nº92, dez., 2000. 8p. (Encarte Técnico).

MORIN, E. A organização (do objeto ao sistema. In: O método). I - A natureza da natureza. 2. Ed. Mem Martim, 1987. Cap II: p 92-145.

MUSSOI, E. M. A formação de agentes de desenvolvimento: estágio de vivência como busca da visão sistêmica a partir da universidade. Encontro em Sistemas de Produção. Resumos. IAPAR, junho, 1993. p6.

MÜLLER, G. Competitividade e integração econômica e social: para uma gestão regional das questões agrárias e agroindustriais, IGCE-UNESP, Rio Claro, n. 32, $1995,49 \mathrm{p}$.

OSTERROHT, M. Açúcar mascavo de Jaboti: 10 anos de pesistência e evolução. Agroecologia Hoje, Anol, n.3, p. 16-18, jun./jul., 2000. 
PASCHOAL, A.D. Pragas, praguicidas e a crise ambiental: problemas e soluções. Rio de Janeiro, FGV, 1979. 102p.

PASCHOAL, A.D. Modelos sustentáveis de agricultura. Agricultura Sustentável, Jaguriúna-SP - EMBRAPA-CNPMA, v.2, n.1, p.11-16, 1995.

PASCHOAL, A.D. Produção orgânica de alimentos. Agricultura sustentável para os séculos XX e XXI. Piracicaba, ed. do autor, 1994. 191p.

PAULILLO, L.F. Redes de poder e complexos agroindustriais. $1^{\text {a }}$ ed. São Paulo: Rima Editora, 2000, (cap. 1).

PIMENTEL, D. The ecological basis of insect pest, pathogen and weed problems. In: Cherret, J.M.; Sagar, G.R. Origins of pest, parasite, disease and weed problems. Oxford, Blackwell Scientific Publications, 1977. p.3-31.

PRIMAVESI, A. M. Manejo ecológico do solo. 9 ed. São Paulo: Nobel, 1987. 549p.

PRIMAVESI, A.M. Manejo ecológico de pastagens. Porto alegre, Centaurus, 1982. 176p.

RAIJ, B. van Avaliação da fertilidade do solo. 2 ed. Piracicaba: Innstituto da Potassa e Fosfato, 1983. 142p.

REIJNTJES,C. et al. Agricultura para o futuro: uma introdução à agricultura sustentável e de baixo uso de insumos. Rio de Janeiro: AS-PTA, 1994. 324p.

ROMEIRO, A.R.; SALLES FILHO, S. Dinâmica de inovações sob restrição ambiental. In: ROMEIRO, A.R.; REYDON, B.P.; LEONARDI, M.L.A. (Org.). Economia do meio ambiente: teoria, políticas e a gestão de espaços regionais. Campinas, SP: UNICAMP.IE, 1996. p.83-122.

ROSNAY, J. Le macroscope, vers une vision globale. Paris, Editions de Seuil, 1975. $305 p$.

RUTTAN, V.W. constraints on sustainable growth in agricultural production: into the $21^{\text {st }}$ century. Outlook on Agriculture, v.20, 1991. p.225-234.

SACHS, I. Qual desenvolvimento para o século XXI? In: Barrère, M. (Coord.). Terra, patrimônio comum: a ciência a serviço do meio ambiente e do desenvolvimento. São Paulo, Nobel, 1992. 
SAUTTER, G. Comision d'audit du Département de Recherche sur les Systèmes Agraires et le Developpement; Rapport géneral.Paris, INRA, 1986. V1, 43p.

SEBILLOTTE, M. Analyse du fonctionnement des exploitations agricoles trajectoire et typologie. Note introcuctive pour la Reunion du SAD. In: INRA-SAD ed. Eléments pour une problematique de recherche sur les systèmes agraires et le développement. Paris, 1979. p. 20-30.

SHIVA, V. The violence of the Green Revolution. London, Zed Books, 1991.

SILVA, J.G. O Novo Rural Brasileiro. Campinas, IE/UNICAMP. Projeto Rurbano, www.eco.unicamp.br/projetos/rurbano7, 1999, $20 \mathrm{p}$.

SILVA, J.G. Perspectivas da agricultura alternativa. Cadernos de Difusão de Tecnologia, v.4, n.2, maio/ago., 1987, p.117-128.

WALLISER, B. Systémes et modéles - Introduction critique a l'analyse de systèmes. Paris, Editions de Seuil, 1977. 253p.

WEID, J.M. Agroecologia e agricultura sustentável. Summa Phytopathologica, v.20, $\mathrm{n}^{\circ} 1$, jan./mar., p.63-67, 1994. 